\title{
LLNL Waste Minimization Program Plan
}

\section{Lawrence Livermore National Laboratory}

\author{
Environmental Protection Department \\ Hazardous Waste Management Division \\ Waste Minimization Program
}

February 14, 1990

Revision 2 


\section{DISCLAIMER}

This document was prepared as an account si work sponsored by an agency of the United States Governmenl. Neither the United States Goyernment nor the Univer ity of California nor any of their emplovees. makes any wartanty, capress or implicd, or astumes any legal liabllity or responsibility for the accuracy, completene ss, or usefulness of any informalion, apparatus, product, of process disclosed, at repiesents that its use would not intringe pribately owned zights. Reference herein to any specitic commercial products. process, or service by Irade name, tradematk, thanulaclurer or olher wise, does not necessarily constitute or imply its endorsemenl recommendation, or favoring by the Uniled Siates Government of the Liniversity of Califumia. The vipws and opinions of authors expressed herein do not necessarily state or sefect those of the linited States Covemment or the L'n: arsity ot Califomiz, and shall not be used for advettising or producl endarsement purposes. 


\section{TABLE OF CONTENTS}

\section{Page}

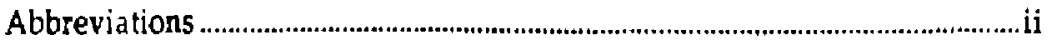

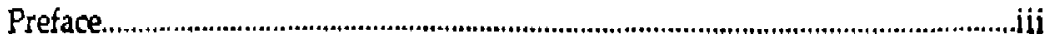

Introduction/Background........................................................................................1-1

Progtam Jbjectives................................................................................................... I-2

Description of Program......................................................................................... 1-2

Descrip

(to date and planned)

Description of Technology Transfer Activities ..................................................1-10

Description of Program Perfon:ance Evaluation ........................................... 1-10

Figures

1. Waste Minimization Strategy.............................................................. I-3

2. LLNL Organization Responsibilities....................................................... 1.5

3. DOE 5820.2A Functional Documentation and Reporting Responsibilities.

Tables

I. Training Efforts

2 Waste Minimization Drivers Effecti- Facilities/Operations............. 1-11

3. Identified Targets of Opportunity.

4. Projected Waste Reductions.

\section{Appendix}

Directorate Mini-Plans for:

Administration and Operations

Beam Research and MFE

Biomedical and Environmental Research

Chemistry and Materials Science

Computations

Energy Program/Earth Sciences

Engineering

Lasers (LIS and ICF)

Nuclear Design

Nuclear Test

Physics

W Program

Z-Division 


\section{ABBREVIATIONS}

DOE

DHS

DP

EPA

HSWA

LLNL

OTA

RCRA

TSCA

TSDF

WRA

WMSC

HWRMRA
Department of Energy

Department of Health Services

DOE Defense Programs

(United States) Environmental Protection Agency

1984 Hazaidous and Solid Waste Amendments to the Resource Conservation and Recovery Act

Lawrence Livermore National Laboratory

Office of Technology Assessment

Resource Conservation and Recovery Act

Toxic Substances Control Act

Treatment, Storage, and Disposal Facility

Waste Reduction Audit

Waste Minimization Steering Committee (LLNL)

Hazardous Waste Reduction and Management Review Act of 1989 (SB14 Robert) 


\section{PREFACE}

This document is the February 14, 1990 version of the LLNL Waste Minimization Program Plan (WMPP). The Waste Minimization Policy field has undergone continuous changes since its formal inception in the 1984 HSWA legislation. The first LLNL WMPP, Revision A, is dated March 16, 1985. A series of informal revision were made on approximately a semiannual basis. This Revision 2 is the third formal issuance of the WMPP document.

Now legislation at the federal level is being introduced. Passage will result in new EPA regulations and also DOE orders. At the state level the Hazardous Waste Reduction and Management Review Act of 1989 was signed by the Governor. DHS is currently promulgating regulations to implemen! the new law.

EPA has issued a proposed new policy statement on source reduction and recycling. This policy reflects a preventative strategy to reduce or eliminate the generation of environmentally-harmful pollutants which may oe released to the air, land surface, water, or ground water. In accordance with this new policy new guidance to hazardous waste generators on the elements of a Waste Minimization. Program was issued. In response to these policies, DOE has revised and issued implementation guidance for DOE Order 5400.1, Waste Minimization Plan and Waste Reduction reporting of DOE Hazardous, Radioactive, and Radioactive Mixed Wastes, final draft January 1990.

This WMPP is formatted to meet the current DOE guidance outlines. The current WMPP will be revised to reflect all of these proposed changes when guidelines are established. Updates, changes and revisions to the overall LLNL. WMPP will be made as appropriate to reflect ever-changing regulatory requirements. 


\section{WASTE MINIMIZATION PROGRAM PLAN}

\section{INTRODUCTION}

The Lawrence Livermore National Laboratory has as its primary mission, the research and development of the nuclear weapors that make up the nation's deterrent force.

The design of the nuclear weapons has been called one of the most challeinging enterprises ever undertaken. Specialists from many disciplines are called upon to predict, test, and analyze the results of an explosion. Astrophysics, piasma physics, atomic and nuclear physics, thermodynamics, hydrodynamico, computational physics, solid state physics, nuclear chemistry, and engineering are some of the disciplines involved. It's not surprising, then, that a multidisciplinary approach is required.

Since the founding of the Laboratory in 1952, the skills of scientists, engineers, technicians, and others have been blended into unique research tams using sophisticated technology to attack formidable problems.

This multidisciplinary approach is, in fact, the embodiment of "Big Physics" of science on the grand scale.

This research takes two forms at Livermore. One is basic research, in which our scientific people work at and beyond the frontiers of science. This "pure science" is typically found at universities. The other form is applied research, similar to that done at industrial laboratories. The use of both kinds of research gives Livermore the capability to move concepts from the fringes of basic research through the development of prototype hardware.

Although the exploration of nuclear weapors ideas remains the foundation stone of the Laboratory, we have assumed greater and more diverse responsibilities as our capabilities have developed. The result has been that, over the years, the expertise gained from the study of weapons has been transferred to other areas at the Laboratory.

Today, our work centers around six major programs. These,are:

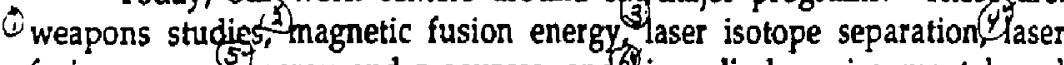
fusion energy, -energy and resources, and biomedical, environmental, and atmospheric sciences.

Moreover, may basic research disciplines - physics, mathematics, and computer science, chemistry, materials science, earth sciences, and 
engineering - help advance the frontiers of knowledge as they support the major programs.

\section{PROGRAM OBJECTIVES}

There is a strong commitment by the Laboratory to minimize wastes particularly hazardous and radioactive wastes. Its importance is reflected by the Director's Statement on Waste Minimization issued on February 27. 1989. "It is important that the Laboratory make a strong commitment to waste minimization - particularly to hazardous and radioactive waste minimization. Our goal is to reduce the Laboratory's hazardous/radioactive waste streams by a major factor in the next three to five years by reducing generation and increasing recycling. We will implement an incentive system where each Laboratory program will pay the costs associated with the handling and disposal of its waste. Each program will establish waste minimization goals and develop plans and assign responsibility for achieving these goals. Waste minimization will be incorporated in the design of new projects." It is consistent with the policy of LLNL to protect its employees, the public, and the environment against the adverse effects of hazardous and/or radioactive materials and their wastes. With the minimization program, LLNL assures another layer of protection through reduction in volume and toxicity of generated wastes.

By implementation of the Director's minimization policy, the overall Laboratory minimization effort will produce a reduction of $25 \%$ to $50 \%$ over a five-year period, in the generation of hazardous, radioactive, and mixed wastes. A range of expected reductions is given since some of the larger generators have existing minimization programs in place. Our previous studies show that misimization efforts produce early reductions which then reduce, in magnitude, with time

\section{DESCRIPTION OF PROGRAM}

Three general methods, in decreasing order of priority, are available for reducing waste generation: source reduction; recyding; and treatment. The hazardous waste management hierarchy (Figure 1) provides a prioritized set of options that will be employed by LLNL facilities. Waste streams from the $\mathrm{Lab}$ have been identified. Reduction activities for each stream will continue or be undertaken as appropriate.

Each directorate has developed a minimization mini-plan for its own waste generation activities. The larger programmatic waste generators will in addition develop micro-plans for specific process operations. Thus a hierarchy of plans exists at LLNL: Overall Plan, Minj Plan, and Micro Plan.

$$
\text { s)inctorate riograms }
$$




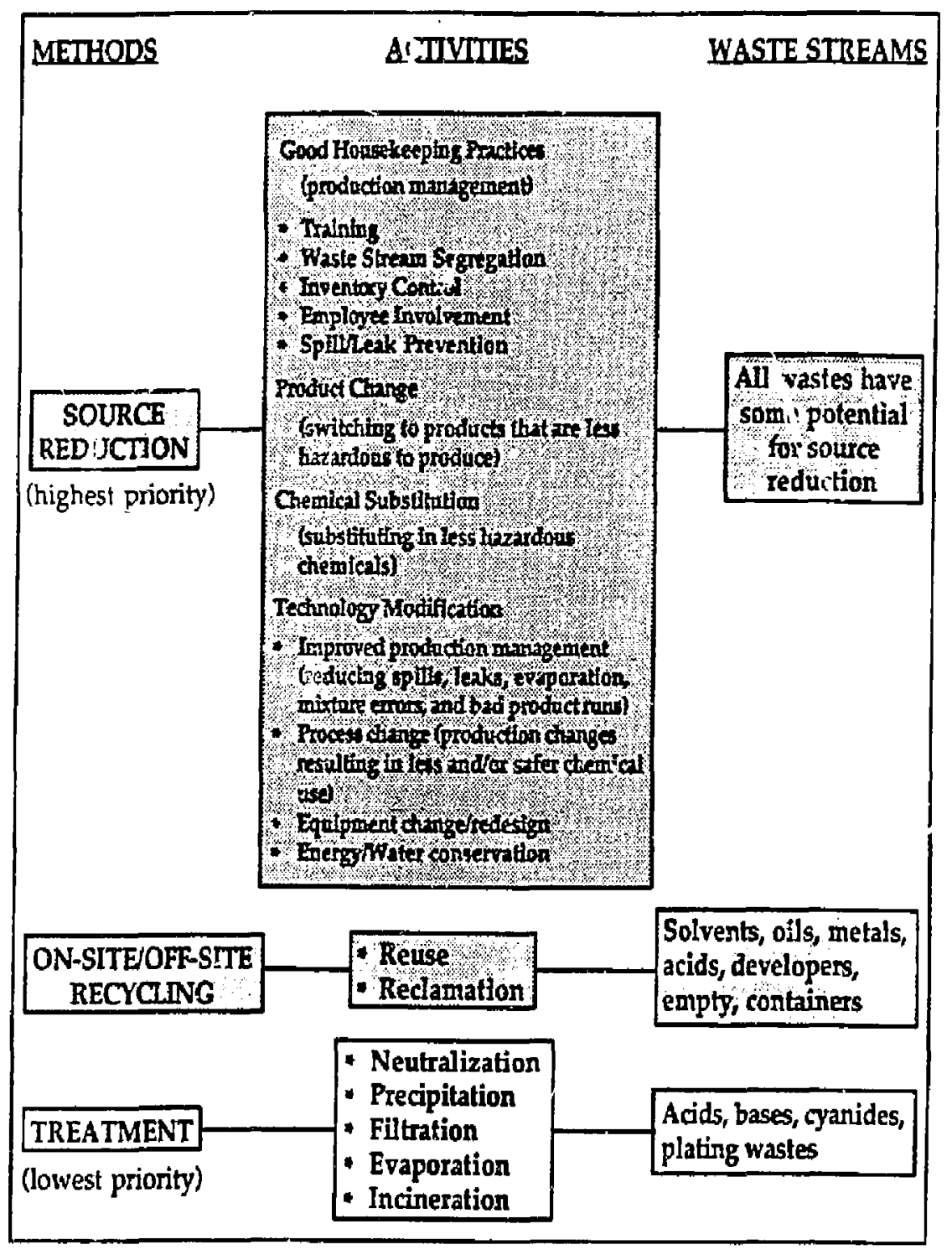

Figdre 1

Waste Minimization Strategy 
Details are shown in the various directorate mini-plans (see appendix).

The Laboratory has studied a hazardous waste techarge system for all programmatic generators so as to fully allocate waste disposal costs to the generators. Originally the recharge plan was to be implemented at the start of FY90. Ambiguity in funding levels from the Department of Energy results from a more recent plan to fund waste management operations as a direct budget line item and has complicated plan to implement a cost incentive based allocation system. Alternatives to the initial recharge program are currently being studied. One of these alternatives will be implemented as final funding levels are determined.

A formal Quality Assurance (QA) Plan calling for an annual program audit of the minimization program plan will be issued. This QA Plan is required by DOE orders and will follow the DOE/SAN office QA Plan, whict: is yet to be issued. In the interim, a draft LLNL QA Plan was issued for internal guidance on August 4, 1989.

The results of the audit will be to verify annual progress on meeting reduction goals and also to identify potential areas for improvement.

Figure 2 shows the waste minimization organization responsibilities at LLNL. In order to meet the requirements of DOE orders and to implement the Director's statement on waste minimization, a Waste Minimization Steering Committee was formed. Each directorate at the Lab appointed a representative to serve on the Committee. The committee's charter included the review and evaluation of the proposed waste recharge system, and development of an auditable waste minimization plan including goals for all appropriate waste streams at the Lab.

Figure 2 shows the interaction/coordination between the Lab generators and DOE programi staff by identifying the functional documentation and reporting responsibilities.

The FY90 budget for planning is $\$ 815 \mathrm{~K}$ and $\$ 100 \mathrm{~K}$ for implementation activities. The requested FY 1 budget is $\$ 1200 \mathrm{~K}$ for planning and $\$ 250 \mathrm{~K}$ for implementation activities.

A waste accounting system is in place. The Hazardous Weste Management Division (HWM) develops and maintains a waste accounting system to track the types, amounts, corrposition, and generation dates of all hazardous wastes. The Facility Hazardous Waste Report is based on data extracted from the HWM database. The total costs of treating, storing, and disposing of waste were analyzed. These costs can also be extracted from the HWM database and reported for each waste stream. 
Figure 2

LLNL Organization Responsibilities

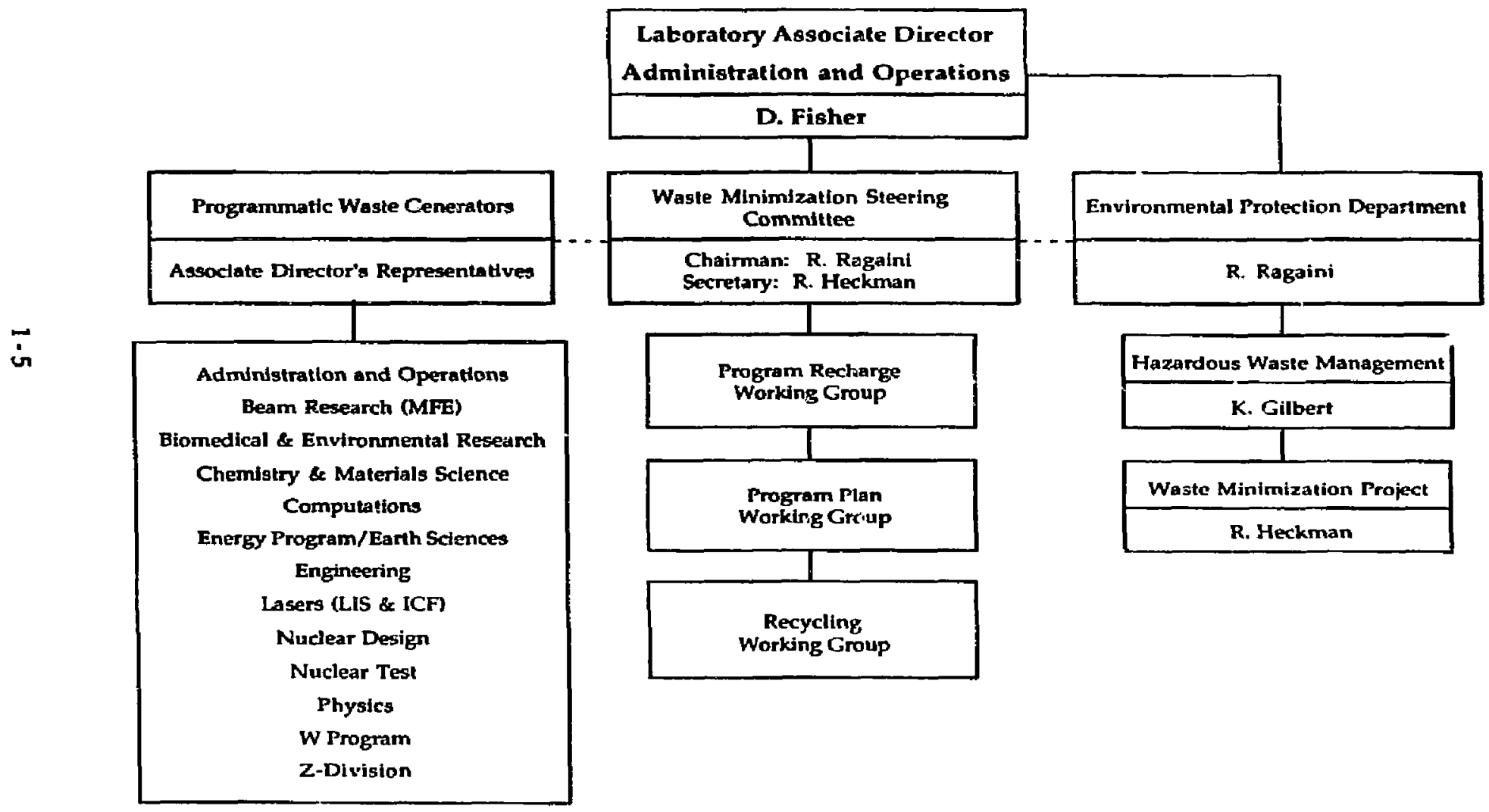


Figure 3

DOE Order 5820.2A

Functional Documentalion and Reporting Responsibilities

Identifies Organizational Interfaces Between the Office of Defense Frograms, the Waste Reduction Program, and the Lawrence Livermore National Laboratory Waste Minimization Project

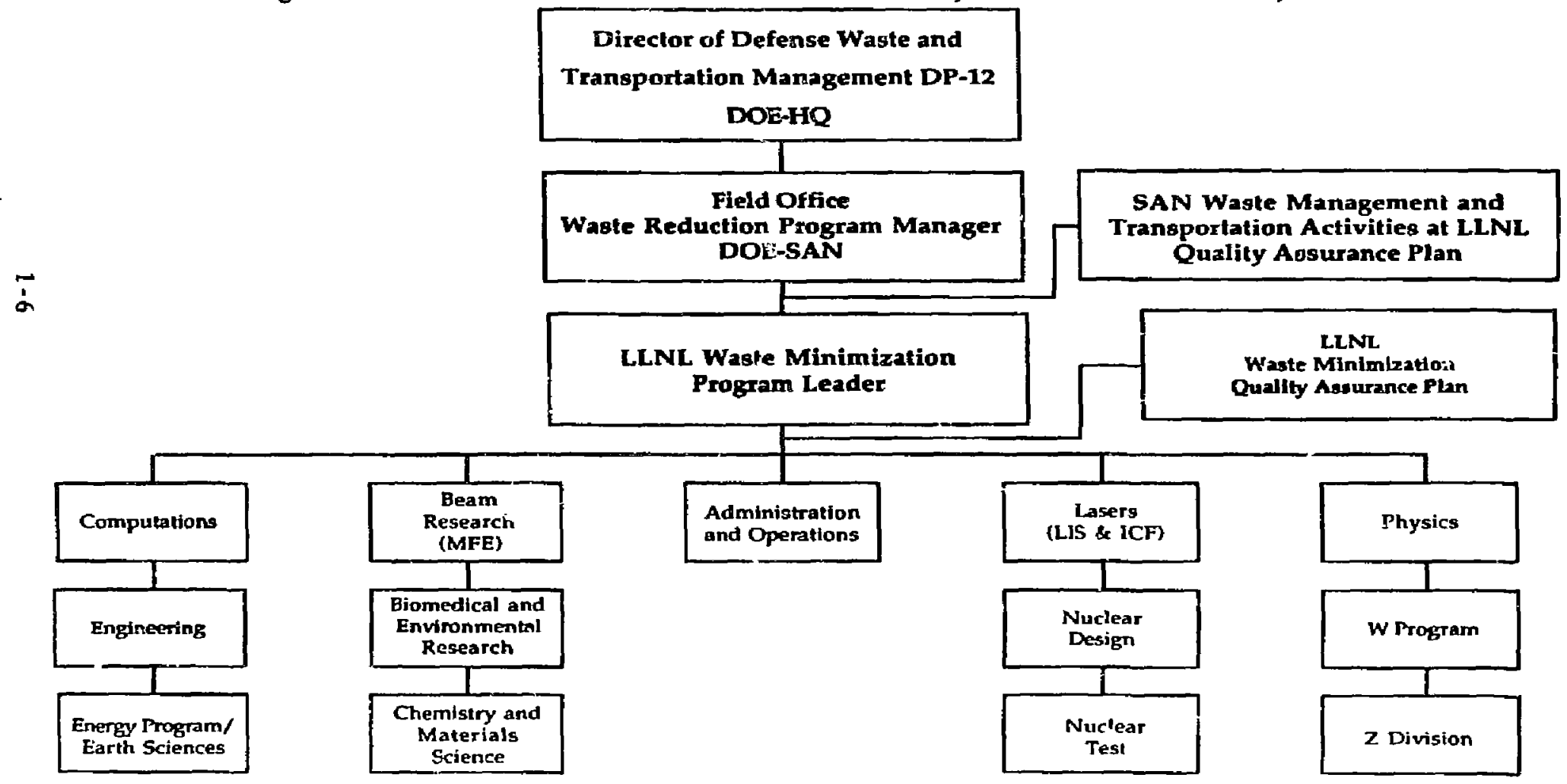

Director of Defense Waste and

Field Office

SAN Waste Management and Quality Aosurance Plan

Srienc.

Test

Z Division 


\section{DESCRIPTION OF WASTE MINIMIZATION ACTTVITIES TO DATE AND SCHEDULE OF PLANNED ACTTVITTES}

As an important part of the "Good Housekeeping Practices" activities, employee involvement and training on Waste Minimization emphasizing updated source reduction techniques and methods, will continue (Figure 1).

Table 1 indicates the extent and na'ure of eisployee and management training in waste redurtion. At this time an employee incentive program is being considered for waste minimization suggestions. Several companies have reported the importance of an incentive program to the success of their waste minimization programs. Other companies have reported successful programs without an incentive program; these companies believe that it is part of each employee's job to reduce or minimize waste.

The Waste Minimization Program will periodically rank waste streams by quantity, toxicity, or prevailing regulatory emphasis. Waste quantities and volumes will be gleared from several sources including the waste generation data base. A waste stream may be selected as a candidate for study and possible implementation of wasie minimization based on a combination of its ranking and the number of other drivers affecting it. A list of regulations and other minimization drivers affecting facilities/operations at LLNL is shown in Table 2. Each of the waste streams may be affected by land bans, disposal costs, new regulations, or SARA Title III Section 313 (which does not currently apply to LLNL). In addirion, radioactive streams are affected by DOE Order 5820.2A.

In special cases, a waste stream may be selected for study and reduction despite its low ranking if a program has an urgent need to reduce its waste or if a commercially proven technology is readily available. This is a case of working smart by choosing the "low isanging fruit" which is ripe for the picking with little effort.

Cost savings are an important factor, but in some insiances may not be the overriding reason for selecting waste streams for minimization. The published literature indicates that government support and incentives may be needed to offset costs. At the plant level, overhead monies may be re uired to assist prograns in paying for waste mirimization. Regulation; appear to be a significant driver now and all indications are that they will continue to be so in the future. The literature reporis that the main driver is fear of future liabilities. 
Table 1

Training Efforts

Extent and Nature of Employee and Management

Training in Waste Reduction

Programmatic Briefings

B-141 Experimental Circuit Board

B-322 Plating Shop

B-325 Cooling Towers

B-151 Nuclear Chemistry

B-411 Supply and Distribution

B-321 Materials Fabrication Division

B-418 Paint Shops

B-4385 MFE

B-611 Motor Pool

All facilities using or handling lead Lead Integrated Management Program (LIMP) Steering Committet

Site 300 weste from firing tables

Waste frenn containers

B-482 LIS
Dates

August 5, 1986

June 18, 1986

July 11,1986

September 10, 1986

March 2, 1987

April 6, 1587

April 21, 1987

April 23, 1987

May 4, 1987

June 17, 1987

November 9, 1987

February 9, 1989

March 2, 1989 


\section{Table 1}

Training Efforts (cont.)

\section{Extent and Nature of Employee and Management \\ Training in Waste Reduction}

\section{Publications}

Environmental Forum

"Minimizing Hazardous Waste"

by R.A. Heckman

The Quarterly

"Managing the Laboratory's

Hazardous Waste"

Nawsline

New pane' formed to study reducing

hazardous waste

Reducing hazardous waste becoming more vital to Lab

Hazardous waste minimization talk set for Thursday

Talk scheduled on hazardous waste

Tuesday A.M. Update

Waste Minimization Committee forming

Waste minimization talk on tap this

Thursday

Waste minimization talk slated for

February 9
February 1, 1989

Dates

February 9, 1989

December 1987

April 19, 1989

February 15,1989

February 8, 1989

April 18, 1989

February 7, 1989

January 31, 1989 
In the work to date for several facilities, several targets of opportunity have been identified for waste reduction, for these, capital costs have been estimated (Table 3). These changes are primarily for process modifications, the third of the sequential phases of source reduction. Some consideration has been given to providing a non-programmatic capital fund to provide these funds rather than facing the bureaucratic barriers and delays when programs directly pay for capitai expenditure. This may be helpful, programs may be less reluctant to identify targets of opportunity for fear that they do not have the funds for implemencation.

The data base for waste reduction is limited in so far as its use as a crystal ball for quantitatively predicting waste reduction for specific waste stream types or industries. Until far more information becomes available, one can only roughly predict that waste minimization for any waste stream will follow the general relationship curve for either hazardous or radioactive waste. Table 4 shows projected waste reductions for various waste streams for the next few years. These rates may be substantially modified as additional data becomes available, the list may be expanded as the waste minimization effort increases in srope.

\section{DESCRIPTION OF TECHNOLOGY TRANSFER ACTIVITIES}

Technology transfer is an integral part of the LLiJl plan. DOE has a formal headquarters Waste Minimization Steering Committee which conducts Working Group meeting several times a year. New technology and applications are discussed at these technical meetings. A DOE electronic bulletin board and mail system, the WIN (Waste Information Network), has a waste minimization section to ensure speedy transfer of technical information. The Environmental Protection Agency has developed a computerized information network, EIES (The Electronics Information System) of the Pollution Prevention Information Clearinghouse (PPIC) also for waste minimization technology transfer. Site 300 has access to these networks through the overall Laboratory Waste Minimization Program Office.

In addition, the Waste Minimization Program office interacts with state, local, trade and academic organizations on waste minimization technologies and makes this information available to the site.

\section{DESCRPTION OF PROGRAM PERFORMANCE EVALUATION}

The site waste minimization effort will be reviewed on an annual basis to identify additional opporturities for source reduction and recycling. These annual reviews will emphasize the application of new technologies for waste reduction as they become known, keeping in mind the options for reducing wastes using the waste management hierarchy (Figure 1). 
Table 2

Waste Minimization Drivers Effecting

Facilities and Operations

\begin{tabular}{|c|c|c|c|c|c|}
\hline $\begin{array}{l}\text { Waste Stream } \\
\text { Number (1) }\end{array}$ & $\begin{array}{l}\text { Land } \\
\text { Ban }\end{array}$ & $\begin{array}{c}\text { DOE Order } \\
5820.2 \mathrm{~A}\end{array}$ & $\begin{array}{c}\text { Disposal } \\
\text { Costs }\end{array}$ & $\begin{array}{c}\text { New } \\
\text { Legislation }\end{array}$ & $\begin{array}{c}\text { SARA Title III } \\
\text { Section } 313\end{array}$ \\
\hline $\mathbf{1}$ & $x$ & - & $\mathbf{x}$ & $\mathbf{x}$ & $x$ \\
\hline 2 & $\mathbf{x}$ & - & $x$ & $\hat{\mathbf{x}}$ & $\hat{x}$ \\
\hline 3 & $\mathbf{x}$ & - & $x$ & $\mathbf{x}$ & $\hat{x}$ \\
\hline 4 & $\mathbf{x}$ & - & $\mathbf{x}$ & $x$ & $\mathbf{x}$ \\
\hline 5 & $\mathbf{x}$ & - & $x$ & $\mathbf{x}$ & $\mathbf{x}$ \\
\hline 6 & $\mathbf{x}$ & - & $\mathbf{x}$ & $\mathbf{x}$ & $x$ \\
\hline 7 & $\mathbf{x}$ & - & $\mathbf{x}$ & $\mathbf{x}$ & $\mathbf{x}$ \\
\hline 8 & $x$ & 一 & $\mathbf{x}$ & $\mathbf{x}$ & $x$ \\
\hline 9 & $x$ & $x$ & $x$ & $x$ & $x$ \\
\hline 10 & $x$ & - & $x$ & $x$ & $\mathbf{x}$ \\
\hline 11 & $\mathbf{x}$ & - & $\mathbf{x}$ & $\boldsymbol{x}$ & $x$ \\
\hline 12 & $x$ & - & $\mathbf{x}$ & $\mathbf{x}$ & $x$ \\
\hline 13 & $\mathbf{x}$ & - & $x$ & $\mathbf{x}$ & $x$ \\
\hline 14 & $\mathbf{x}$ & - & $x$ & $x$ & $x$ \\
\hline 15 & $\mathbf{x}$ & - & $x$ & $\boldsymbol{x}$ & $x$ \\
\hline 16 & $x$ & - & $\mathbf{x}$ & $x$ & $x$ \\
\hline 17 & $x$ & - & $x$ & $x$ & $\mathbf{x}$ \\
\hline 18 & $\mathbf{x}$ & - & $\mathbf{x}$ & $x$ & $x$ \\
\hline 19 & - & $\mathbf{x}$ & $\mathbf{x}$ & $x$ & $x$ \\
\hline 20 & - & - & $x$ & $x$ & $\mathbf{x}$ \\
\hline 21 & $x$ & - & $\mathbf{x}$ & $\mathbf{x}$ & $\mathbf{x}$ \\
\hline 22 & - & $\mathbf{x}$ & $\mathbf{x}$ & $\mathbf{x}$ & $x$ \\
\hline
\end{tabular}


Table 3

Identified Targets of Opportunity

Fiscal Years [\$1M $=\$ 1,000,000]$

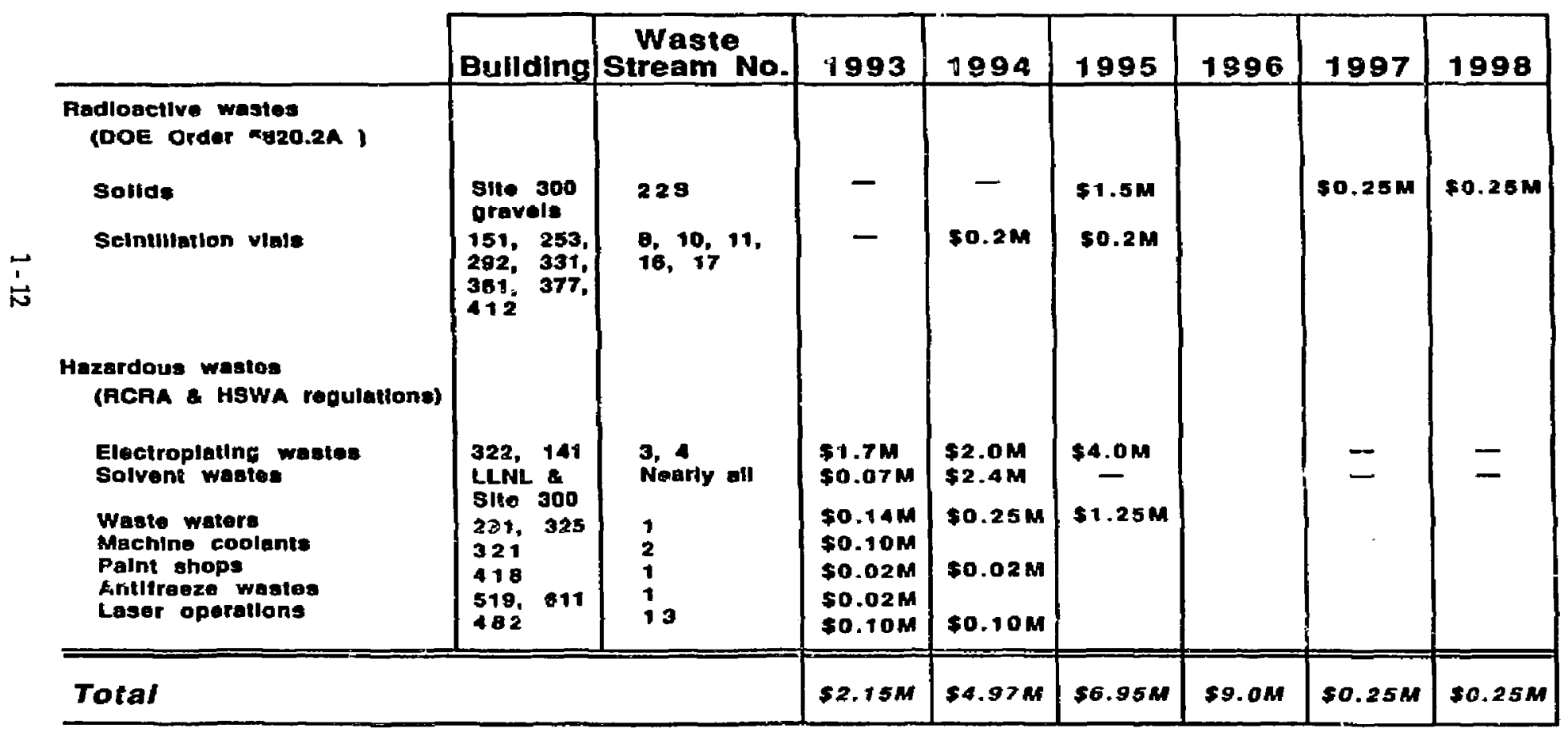


Table 4

Project Waste Reducfions

Radioactive wastes

Sollds

Scintiliation vials

$\overrightarrow{\dot{\omega}}$

Hazardous wastes

(RCAA \& HSWA regulations)

Electroplating wastes

Solvent wastes

Waste waters

Machine coolants

Paint shop aqueous wastes

Antifreeze wastes

Gallons (unless otherwise specified)

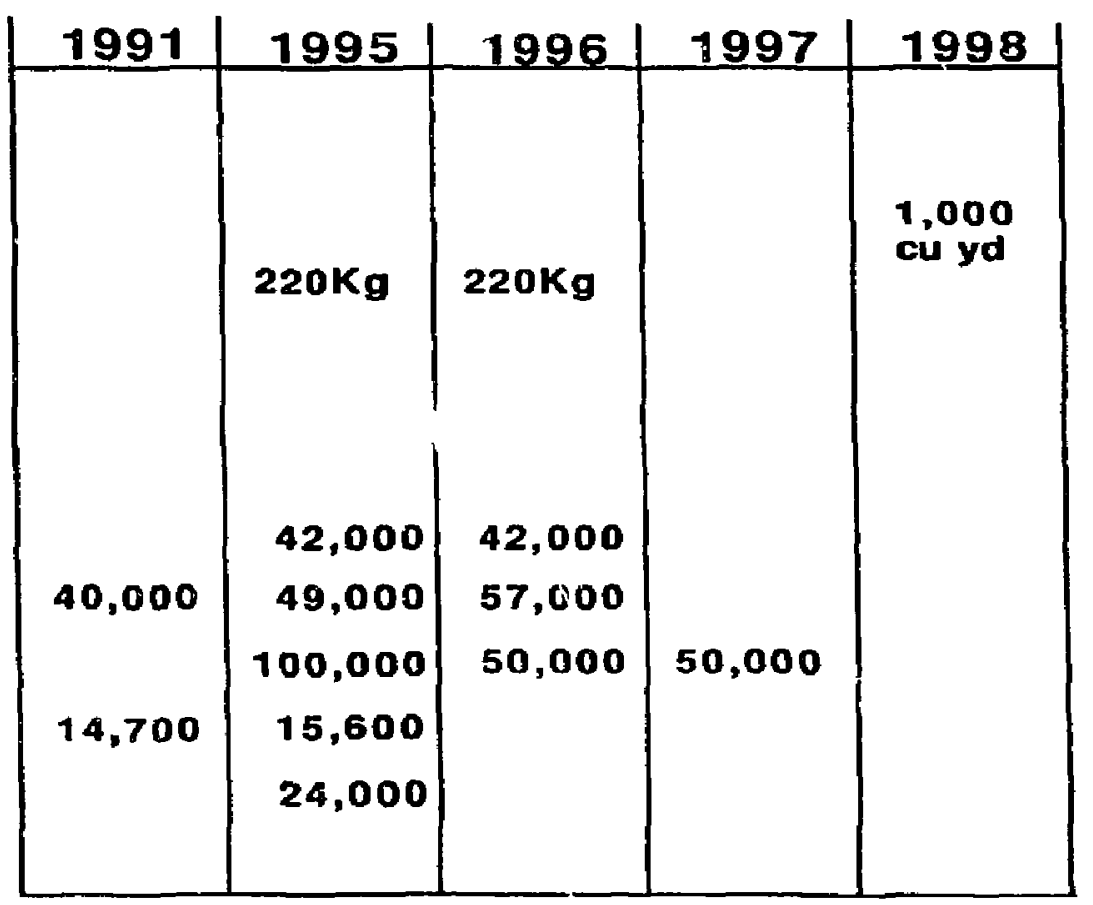


APPENDIX

\section{DIRECTORATE MINI PLANS}




\section{DIRECTORATE MINI PLAN}

$$
\text { for }
$$

ADMINISTRATTION AND OPERATIONS 


\section{Administration \& Operations Directorate Waste Minimization Plan}

\section{April 1990}




\title{
Administration \& Operations Directorate Waste Minimization Plan
}

\author{
April 1990 \\ Richard A. Heckman \\ Jullo C. Diaz \\ Environmental Protectlon Department
}

Lawrence Livermore National Laboratory

University of California, Livermore, CA. 94550 


\section{Contents}

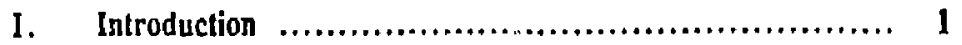

II. Program Objectives..................................... I

III. Description of Program......................................... 1

IV. Description of Waste Minimization Activities

To-Date and Schedule of Planned Activities................. 3

v. Description of Technology Transfer Activities............. s

VI. Description of Program Performance Evaluation............ S

Attachment 1. Director's Statement on Waste Minimization..... 6

Attachment 2. Plant Engineering Print Room...................... ?

Attachment 3. Space and Site Planning Graphics Group....... 8

Attachment 4. Plant Engineering Craft Shops Flowsheets ......,

Attachment 5. Plant Esigineering Classified Waste Paper and

Asbestos Abatement Flowsheets............... 10 


\section{Introduction}

The Lawrence Livermore National Laboratory was established with the primary mission of research and development of nuclear weapons. However, the multidisciplinany approach taken in this work has led to the ass amption of more diverse responsibilities. Today, our work centers around six major programs. These are: weapons studies, energy and resources, laser isotope separation, laser fusion energy, biomedical and almospheric sciences, and environmental sciences. To support the diversity of such research operations, Livermore has establisher he Administration and Operations (A\&O) Directorate. The A\&O Directorate encompasses a wide variety of activities in support of the Laboralory. In fact, the A\&O activities could best be compared to a medi,jm sized industrial park with a diversity of independent facilities/operations.

\section{Program Objectives}

AäO has placed a high priority in establishing and implementing a waste minimization program plan. The A\&O Directorate has adopted the Director's Statement On Waste Minimization (Attachment 1), issued in February, 1989. In the process of implementing the policy. A\&O has formed the A\&O Waste Minimization Committee (Fig. 1) and assigned the associated responsibilities to top management personnel. A\&O also prepared a Waste Minimization Miniplan.

To meet the goals of our policy, the inlormal waste minimization activities already in place have been reviewed and updated where necessary. These early waste minimization efforts were driven primarily by ever increasing off-site disposal costs. Administrative controls, modified operating procedures and installation of new equipment will provide the necessary source reduction achievements. As regulatory and DOE criteria for waste reduction success demonstration become final, these criteria will be addressed and a revised mini-plan will be issued.

Further implementavion of minimization efforts will produce a reduction of $25 \%$ to $30 \%$ over a five year period (see Fig. 2). This is relatively low in magnitude because many of our minimization activilies started as early as 1986, and have already produced significant reductions. Greater reductions may be attained if process modifications and new technologies can be applied to our support efforts.

\section{Description of Program}

Three general methods, in decreasing order of priority are available for reducing waste generation: source reduction; recycling; and treatment. The hazardous waste management hierarchy (Fig.4) provides a prioritized set of options that will be analyzed by LLNL facilities. Waste streams from the A\&O Directorate have 
been identified. Reduction activities for each stream will continue or be undertaken as appropriate.

Employee awareness and training has been addressed through mandatory lormal training sessions. These were given in the summer and fall of 1989. Training activities will continue and will be reviewed on an annual basis.

Waste minimization incentives, such as employee-oriented incentive and award programs can not be implemented without Laboratory-wide approval, and will probably be managed at that level.

The A\&O Directorate emcornpasses a wide variety of activities in support of the Laboratory. These activities and the organizational stucture of the A\&O Waste Minimization Program are shown in Fig.3. Many of these activities generate vastes and are of such diversity that they must te reviewed independently. A summary of the waste generating activities follows. In all minimization activities, the options for reducing wastes are considered based on the waste management hierarchy depicted in Figure 4.

The Hazardous Waste Management (HWA) Division operations generate hazardous, radioactive and mixed-wastes in the Decontamination lacilities al Building 419 , and as a result of chemical analysis activities in the Environmental Analytical Science Laboratory in Buildings 222 and 226. HWM also operates the Laboratory's silver recovery process located in Building 411. The total volumes of waste generated are small.

The Hazard Control Laboratories generate small waste streams from bio-assay analysis and some low level radioactive waste streams.

The Medical Depantment laboratories generate small volumes of wastes, including "sharps", in pertorming routine physical examinations for current and prospective employees. The total volumes of infectious waste generated are sinall.

The Automotive Fleet Division vehicle maintenance operations generate the usual garage type waste streams. Due to State of California regulations, an extensive network of off-site recyclers can provide commercial recycling services. For several years the maintenance operations have taken advantage of these services. Waste motor oils are recycled. "Salefy Kleen" provides a solvent recycle service including equipment for smail parts cleaning which significantly reduces waste solvent wastes. OH-site recycling of anti-treeze wastes is being implemented.

The Technical Information Department photo labs generate modest size waste streams in support of Laboratory wide activitios. The principal waste streams are $\mathrm{film}$ rinse waters.

The Plant Engineering Department is responding to the impact of the Montreal

$\checkmark$ Protocol on the reduction and eventual elimination of chlorofluorocarbons (CFCs), e.g. the Frecns, for use in refrigerants and air conditioning. The 
Department is also responsibje for operation of the Laboratcry wide Low Conductivity Water Cooling Systern. In 1986, significant changes in operating procedures produced large reductions in wastes associated with operation and maintenance of this system.

The Plant Engineering Department also has two small processing units in Buildings 551 and 3778 . Waste silver solutions are sent to HWM tor silver recovery. Additionally, a Diazo printing operation (see Attachment 2) produces about one ton of wasles per year.

The-Space and Site Planning Group of Plant Enginesring also runs a

$\checkmark$ photoprocessing operation. Attachment 3 details their waste quantity and c.umposition.

The Flant Engineering Cratt Shops currently generates large volumes of rinse waters in the spray booths and otier cleaning and maintenance operations. A tyachment 4 contains flowsheets describing these operations and wastes generated.

Plant Engineering also generates classitied waste paper and asbestos contaminated wastes. These waste streams are detailed in Attachment 5.

Saleguards and Security generates a very small waste stream from their equipment cleanigg operations. They have already substituted the use of chlorimated solvents with a water based cleanser.

\section{Description of Waste Mirimization Activities To-Date and Schedule of Planned Activities.}

Informal waste minimization activities already in pluce have been reviewed and where necessary updated. Additionally, administiative controls, modified operating procedures and installation of new equipnient will provide the necessary source reduction achievements.

Waste minimization activities exist for each of the waste streams identified in Section III, above.

Source substitutio:! is the principal reduction tool for the Hazarcious Waste Management (HWM) Division operations. Work on substitution of water and propretary commercial compounds for acid and/or organic solvent decontamination fluids continues and provide a promising technique for reduction by substitution of non-hazardous solvent to Eliminate generation of a mixed waste siream.

Admiristrative control will be the principal source reduction method for the Hazard Control Laboratories. This also applies to the Automotive Fleet Division's vehicle maintenance operations. 
To significantly reduce the waste from the Technical Information Department photo labs there are plans to install a low lemperature vacuum evaporation process unit in order to recycle the rinse water feed. Concentrated silyer solutions are sent to HWM's 411 silver recycling facility. Installation of the vacuum water recycling units should allow achievement of significant reduction in waste generation.

Installation of a centrifuge to separate paint sludge and solvents trom the rinse water thereby aliowing recycle of the water back to the spray boolhs will significantly reduce the generation of this waste stream.

Engineers in Plant Engineering's Design Division are choosing different Freon mixtures toi air conditioning design tor new and proposed buildings. A detailed engineering study is underway of existing air conditioning systems to study retrofit problems for existing systems. Future impacts on capital funds for system replacement and retrofit costs will be large. Operating costs for these systems will also be large. Projected costs for the Freon replaceme:- show a factor of up 1030 times greater costs for the replacements. As more intormation becornes available this section of the mini-plan will be updated.

Waste minimization is also being implemented through changes in operating procedures and through purchasing policies. The Supply and Distribution Department has initiated two very useful changes in procedures that reduced use of hazardous materials by the Laboralory overall. In 1986, S \& D started issuing organic and chiorinated solvenls in 5 gallon containers insfead of 55 gallon drums. The use of solvenis decreased nearly a factor of 10 by his new procedure. $S \& D$ is changing its chemical stocking procedures so that laboratory chemicals will be delivered directly from the wholesale distributor rather than being carried in the main storeroom. This procedure will minimize the generation of out-ofdate/over-age waste chemical reagents that must lab packed for off-site disposal, an expensive disposal method. As the Hazardous Chemicai Tracking System matures, additional procedural modifications may produce other source refuction achievements by the S\& D Depantment.

Work on integrating possitle procedural changes in the handling of purchase requests oy the Purchasing Department to minimize the purchase of both the quantity and type of hezardous materials is starting. How to achie: $\theta$ the objective of minimizing the purchase and use of hazardous materials or perhaps substituting non-hazardous materials with the shortest of administrative procedures to reduce programmalic impacts is the goal.

The reduction of the amount of waste paper sent to the local sanitary landfill by recycling waste office paper is one of our goals. A Recycling Working Group, reporting to the overall WMSC, has been organized and is currently evaluating commercial recycling alternatives.

We will also be investigating the substitution of non-plastic containers by the cafeleria coniractor for the various types of loos containers currently used.

Elimination of styrofoam would be one objective. An initial meeting with the Cafeteria contractor has occurred. Alternatives are under study. 


\section{Description of Technology Transfer Activities}

The A\&O Waste Minimization Plan includes numerous technology transler activilies. These activities are based throughout different divisions and at different management levels. High level management personnel are involved in the LLNL Waste Minimization Steering Committee, and are members of the Program Recharge, Program Planning, and Recycling Working Groups. Also, A\&O personnel have attended professional meetings on subjents such as environmenta law and wasle management.

A.8O personnel keep informed of technical advances via membership in bulletin boards such as DOE's Waste Information Network, EPA's EIES (Electronic Information Exchange System) and, the Superfund/Solid Waste Technology Transfer Electronic Bulletin Board. In addition, personnel throughout the Direclorate interact heavily with state, local, trade, and academic organizations on waste management and minimization.

\section{Description of Program Performance Evaluation}

The A\&O waste minimization effort will be reviewed on an annual basis to identify additional opportunities for source reduction and recycling. These annual reviews will emphasize the application of new technologies for waste reduction as they become known, keeping in mind the options for reducing wastes using the waste management hierarchy (see Fig. 4). 


\section{A\&O Waste Minimization Program}

Functional Responsibilities

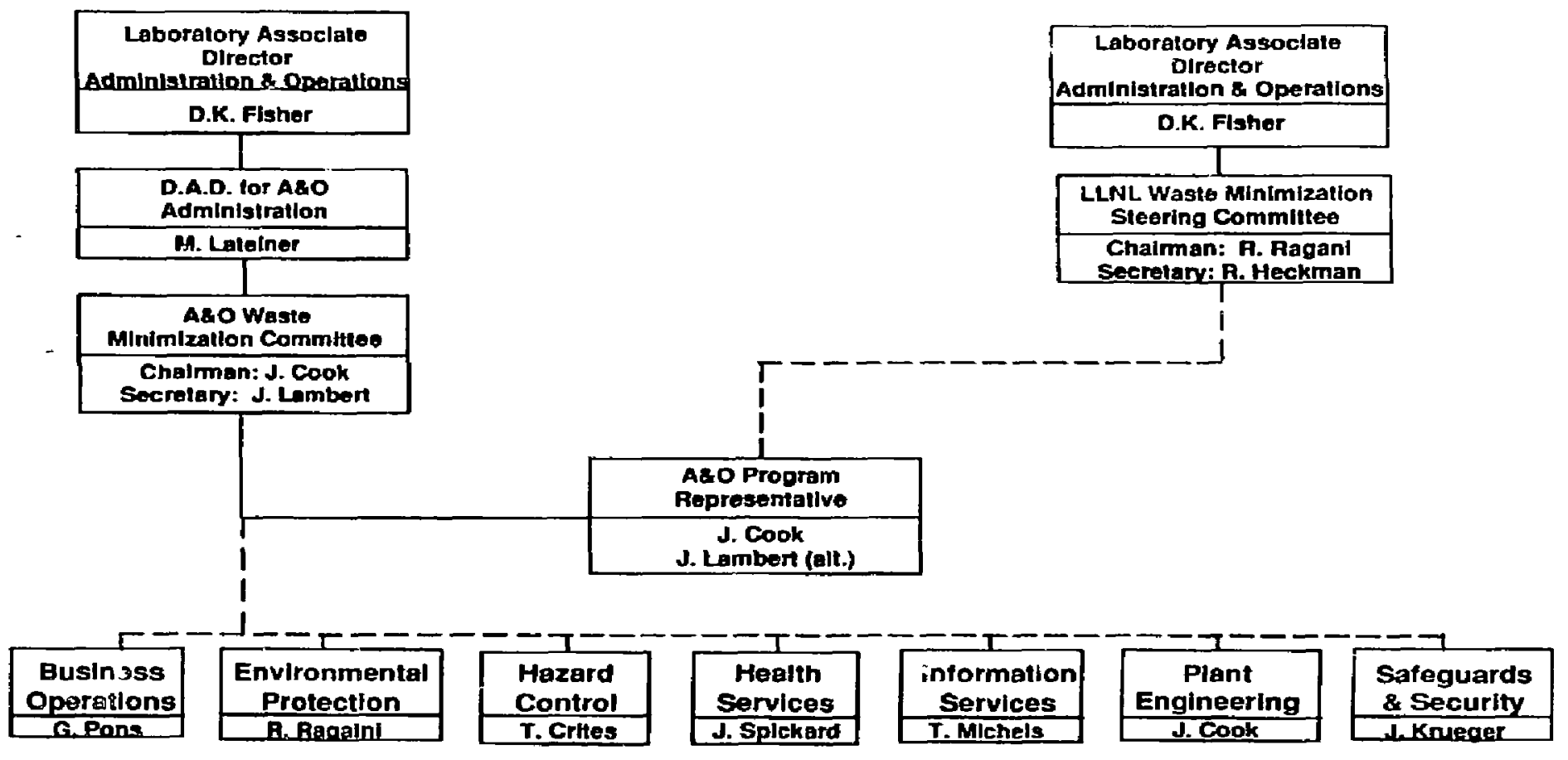




\section{A\&O Waste Minimization Program}

Projected Waste Reduction

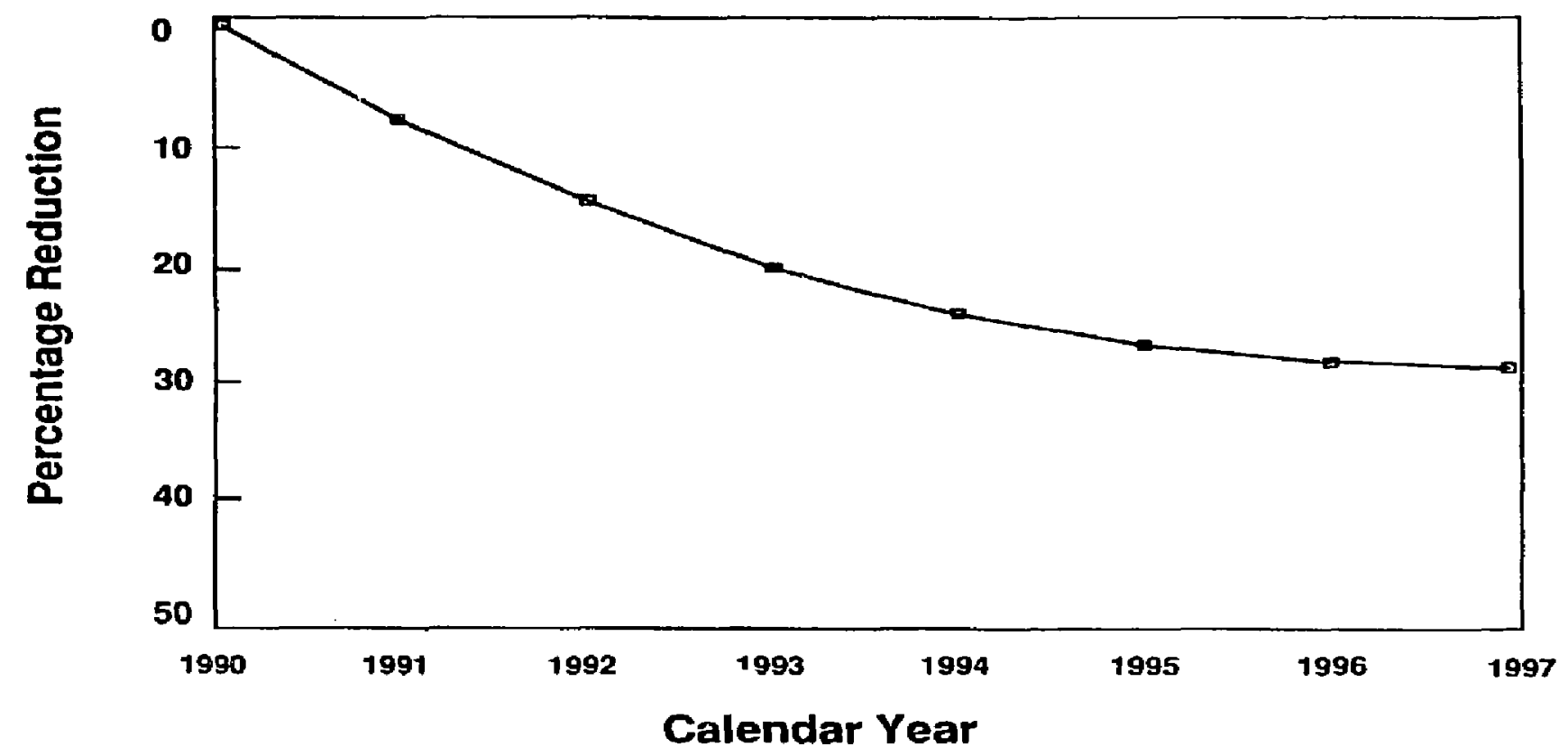

Figure 2 


\section{A\&O Waste Minimization Program \\ Hierarchy of Waste Minimization Plans}

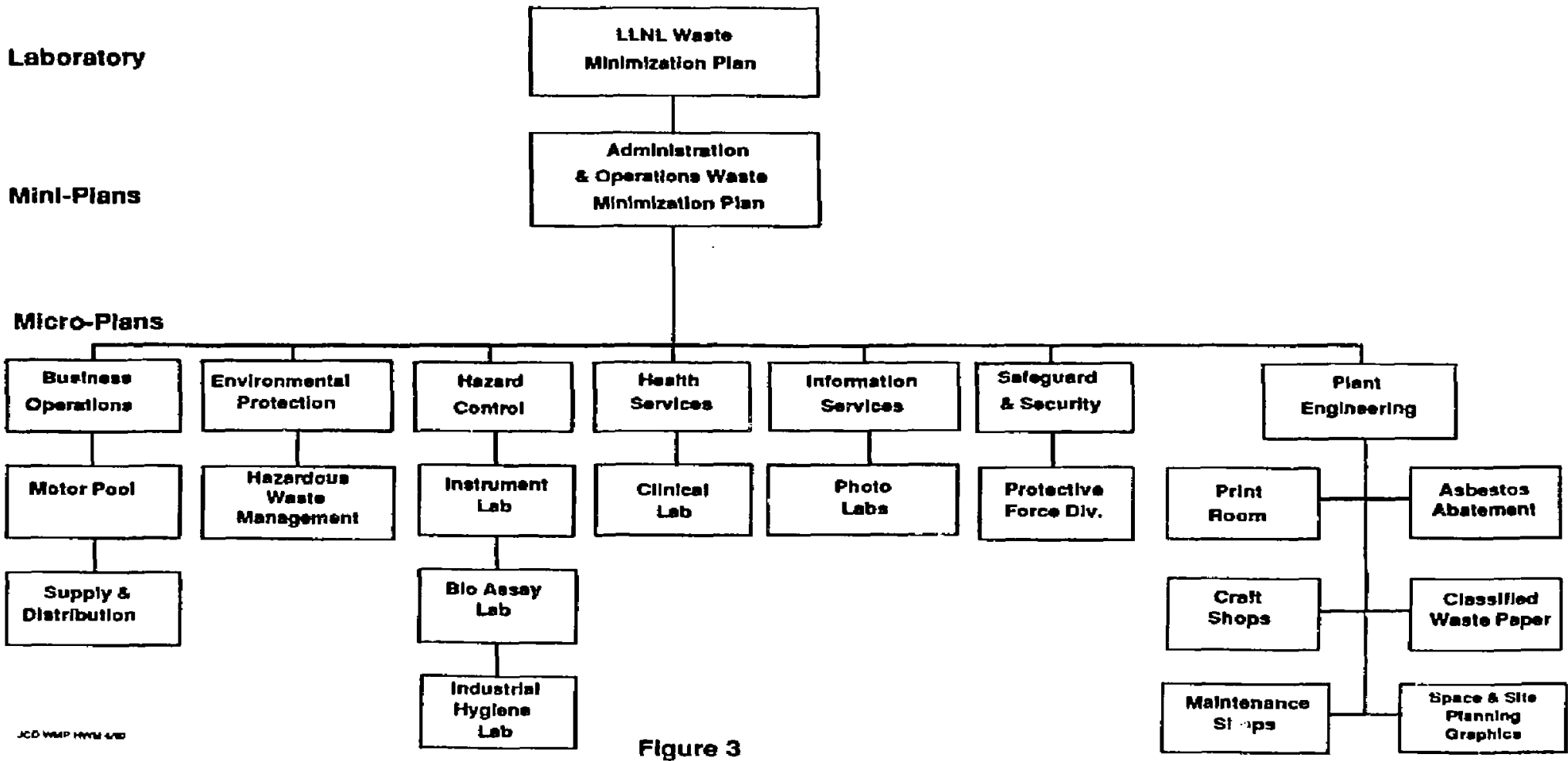

Flgure 3 
Figure 4

Options for Reducing Wastes Using the

Hazardous Waste Management Hierarchy

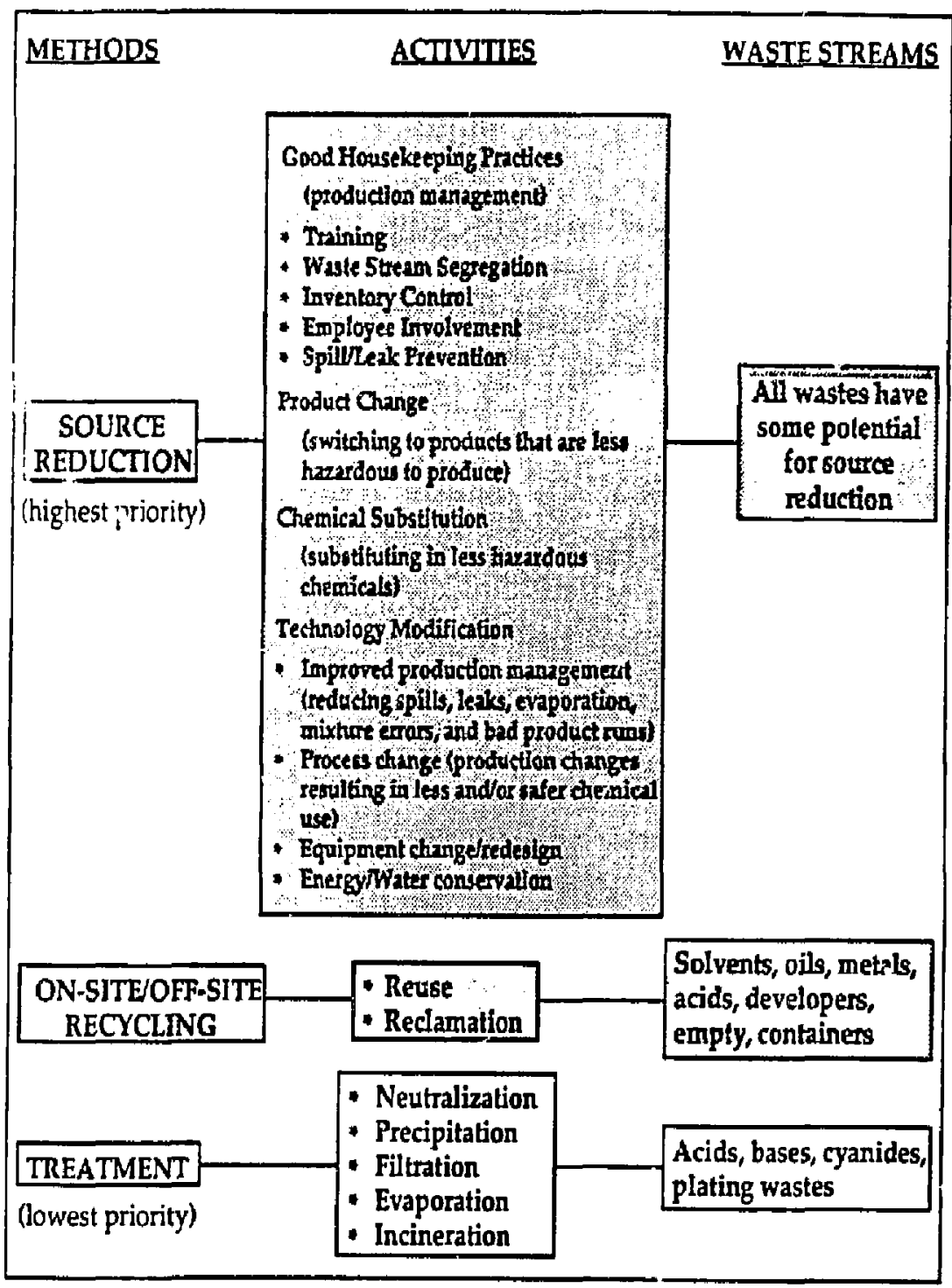




\section{Attachment 1. Director's Statement on \\ Waste Minimization}

\section{DIRECTOR'S STATEMENT ON WASTE MINIMIZATION}

It is imporant that the Laboratory make a strong commitment to waste minimization - to substantially reduce waste generation and increase recycling. Our goal is to achieve a significant overall reduction in the nexi few years. We plan to implement an incentive system where each Laboratory program will pay the costs associated with its wastes. Each program will also establish uaste minimization goals and to develop plans and assign responsibility for achieving these goals.

John H. Nuckolls

Director 
Attachment 2. Plant Enginearing Print Room

$\bullet$

0

0

$\bullet$

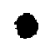

$\bullet$ 


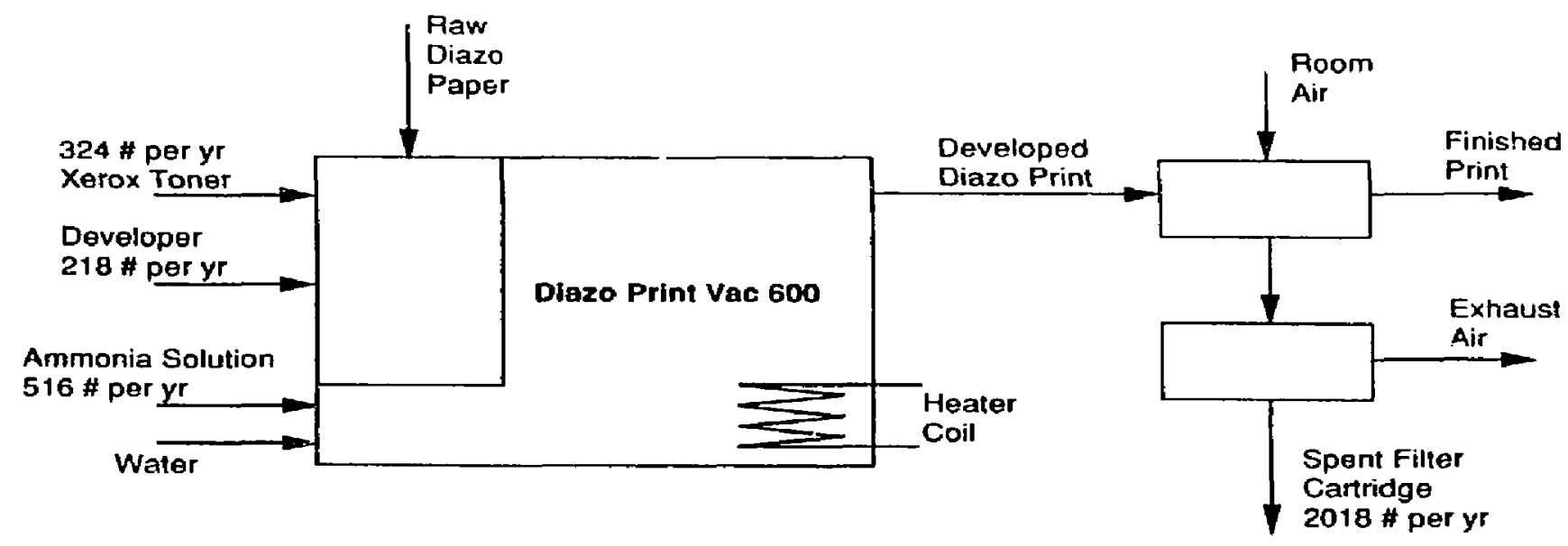

Plant Engineering Print Room

Attachment 2 


\section{Aftachment 3. Space and Site Planning Graphics Group}

The Space and Site Planning Group uses Kodak ltek Fixer, Kodak Itek Universal Developer, and Agla-Gaeven Itek Instacolor Activator in photoprocessing cameras. This use leads to the generation of 876 lbs. of waste (of these spent chemicals). The attached sheets detail material balances and composition of these chemicals. 


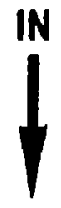

\begin{tabular}{|c|c|c|c|c|}
\hline COMPONENT (S): & Percent & IIV. & Accesclon No: & CAS Reg. RO. \\
\hline Water & $65-70$ & - & 035290 & $7732-18-3$ \\
\hline Amonlus thio: & $\begin{array}{l}\text { If } 15 c \\
15-20\end{array}$ & - & 909586 & $1183-18-8$ \\
\hline Amonive thloc & $\begin{array}{l}2 \text { nate } \\
10-15\end{array}$ & - & 900433 & $1962-95-6$ \\
\hline Acetic octo & $2-3$ & $10 \mathrm{ppo}$ & 900763 & $64-19-7$ \\
\hline
\end{tabular}

\section{SPENT}

\begin{tabular}{|c|c|c|c|}
\hline antoonium thiosulfate & 15 & 10 & 7 \\
\hline amonius thiocyanate & 10 & 5 & $\bar{z}$ \\
\hline acetic acid & 3 & 0 & 2 \\
\hline water & \multicolumn{2}{|c|}{ balance } & \\
\hline silver & 600 & 200 & ppre \\
\hline nickel & 3 & 0 & ppm \\
\hline $\mathrm{pH}$ & 6.5 & 5.5 & \\
\hline
\end{tabular}




\section{Agfa-Gaevert Itek Instacolor Actlvator \\ Agra-Gaevert itek Instacolor Actlvator}

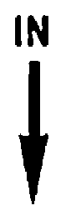

ingrediente/synonya:

Helnylpropylpanediol

CAS No.

$78-26-2$

$105-00-0$

Cyclohe xonediuethenol

$7601-54-9$

itjodiuc Phosphate

$1310-73-2$

\begin{tabular}{|c|c|}
\hline PLRCTNTAGL & $I L V(U, n j t)$ \\
\hline$\overline{1}=58$ & $=$ \\
\hline $1-58$ & $\ldots$ \\
\hline 1.58 & -- \\
\hline $1-5$ & $2=g / 0^{3}$ cedling \\
\hline
\end{tabular}

Sodiua Hydroxide

1

\section{SPENT}

\begin{tabular}{|c|c|c|c|}
\hline methylpropanedisl & 5 & 1 & 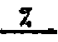 \\
\hline cyclahexaned ime thanol & 5 & 1 & $\pi$ \\
\hline crisodium phosphate & $\underline{s}$ & 1 & $z$ \\
\hline sodium hydroxide & 5 & 1 & $\underline{\underline{I}}$ \\
\hline alkalipe.streneth & 12 & 6مص & N \\
\hline silver & 10 & 5. & Dpg \\
\hline chromium & 1. & 0 & \\
\hline
\end{tabular}




\section{Kodak Itek Universal Developer}

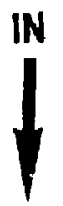

SECTIOM II. HAZARDOUS INGREDIEMTS (TYPICAL YALUES-KOI SPECIFICATIOHS)

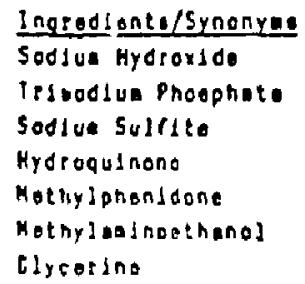

Ingred onte/Synonyes
CAS Ho. 13]0-7J-2 $7601-50-9$ $3757-83-7$ $123-31-9$ $2658-37-1$ 109-83-1
$36-81-3$

\begin{tabular}{|c|c|}
\hline PEACEHTACE & ILV (UnIte) \\
\hline Leee than 18 & $200 / 0^{3}$ Coiling \\
\hline $1 \cdot 39$ & $\ldots$ \\
\hline $1=55$ & $\ldots$ \\
\hline $1 \cdot 58$ & $209 / 0^{3}$ \\
\hline toot then 18 & $\ldots$ \\
\hline $1-58$ & $\ldots$ \\
\hline $1-35$ & $30 \times g / 0^{3}(101)$ \\
\hline
\end{tabular}

\begin{tabular}{|c|c|c|c|}
\hline Sodiun hydroxide & 1 & 0 & 2 \\
\hline trisodiun phosphate & 5 & $\perp$ & 2 \\
\hline sodium sultite & 5 & 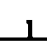 & 2 \\
\hline hydroqutinone & 5 & 1 & 2 \\
\hline methyl aminoethanol & 5 & 1 & 2 \\
\hline Blycerine & 5 & 1 & 2 \\
\hline Hater & hal & 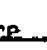 & \\
\hline silver & 1 & 2 & spon \\
\hline chromius & .55 & 0 & por \\
\hline $\mathrm{pH}$ & 11.3 & 30. & _ \\
\hline
\end{tabular}


Attachment 4. Plant Engineering Craft Shops Flowsheets 


\section{OILS, SOURCE - BUILDINGS $511 \& 519$}

Waste oil streams are a by product of normal routine maintenance performed on various plant equipment, i.e. chillers, compressors, heavy equipment. Other oil waste streams that are generaled by the Programs are normally vacuum pump oil and in the high voltage area, the change out of transtormer oil.

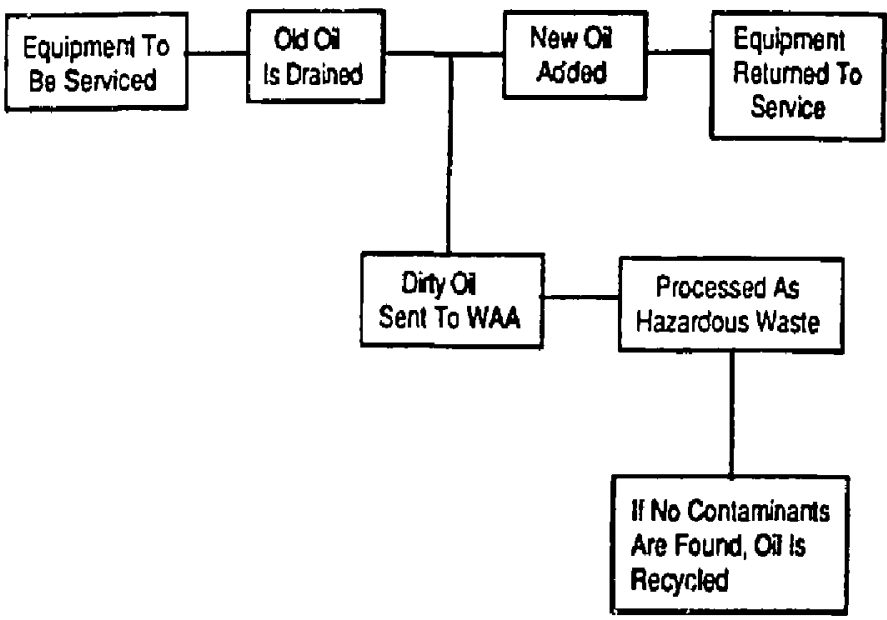

Total pounds per year $\mathbf{5} \mathbf{5 2 , 0 0 0}$ 
Rinse water waste stream is a by-product of the spray booth operation in Building 418. Water is used to trap the paint spray mist and is pumped out into holding lanks.

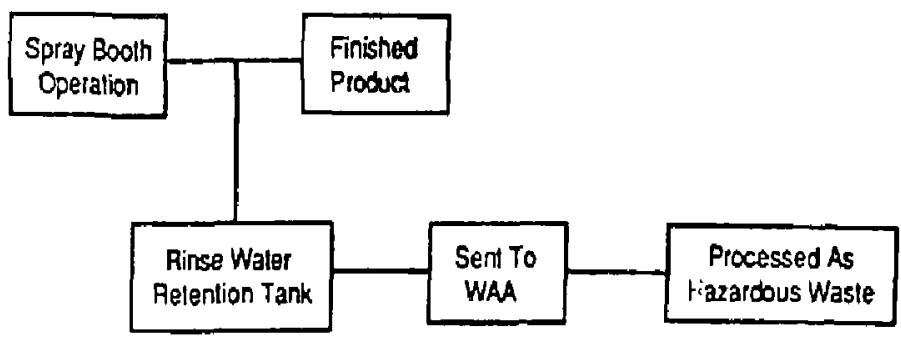

Total pounds per year - 20,000 


\section{SLUDGE, SOURCE - BUILDING 519 STEAM CLEANING AREA}

Heary equipment, tools and pumps require periodic steam cleaning. The result of this activity is an oil, dit sludge that is collected in the sump of the steam cleaning area. The sump is cleaned out on a regular basis, the sludge is put into drums and processed as hazardous waste.

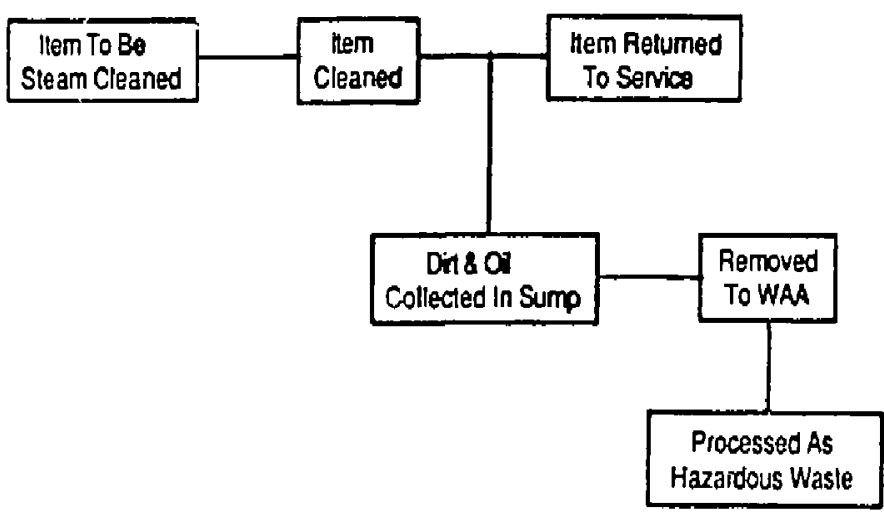

Total pounds per year $-4,500$ 


\section{FREON, SOURCE - BUILDING 511}

Freon waste streams are primarily a by-product of various cleaning activities. Those lypes of activities are high pressure regulalors and vacuum pump overhauls.

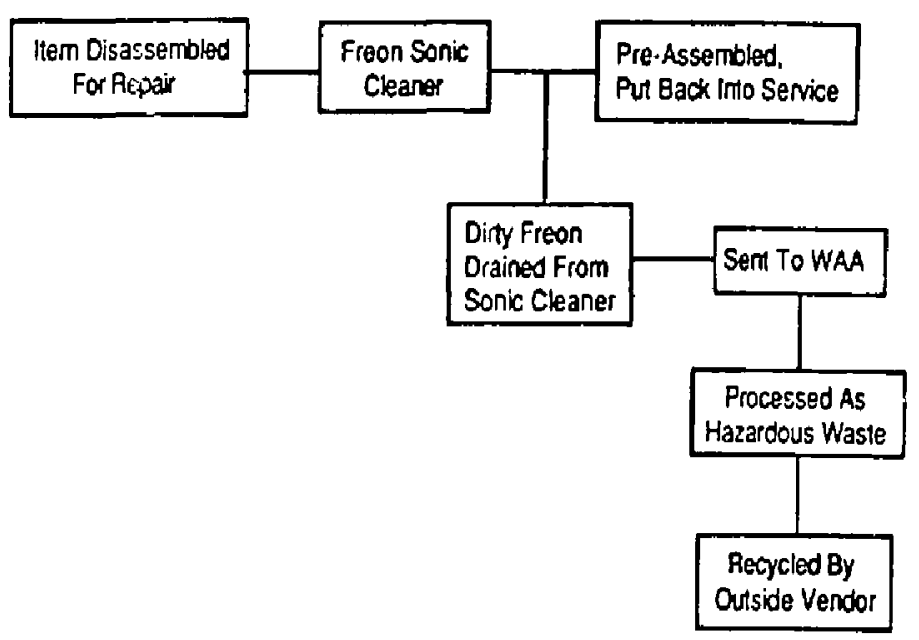

Total pounds per year $-3,200$ 


\section{PAINT, SOUACE - BUILDING 418}

General use is primarily in refurbishment of lacilities and structures. Other uses as in the paint coating of programmatic items and experimental as well as normal aeslhelics use. This waste stream provided by this activity is leftover paint that cannol be re-used due 10 special mixing of colors as well as unique properties ol some products like epoxy base.

\section{Process}

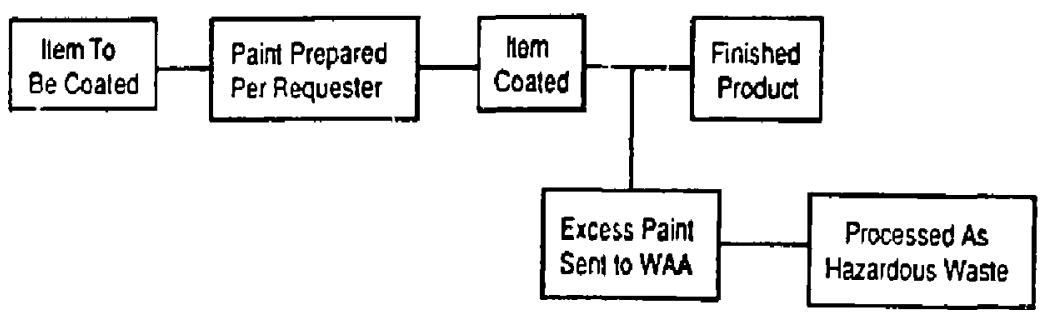

Total pounds per year $-18,600$ 


\section{PAINT THINNER (LACOUER \& SOLVENT) SOURCE - 30\% LABOR ONLY, $70 \%$ BUILDING 418}

Primany use of this product is for thinning paint and other coating products. Cleaning $\mathrm{ol}$ coating equipment such as sprayers, brushes and rollers in the primary use of the solvent based thinner. Waste streams that are produced in the use of these products are mixed coating and thinner residues and dirty solvent thinner after cleaning equipment.

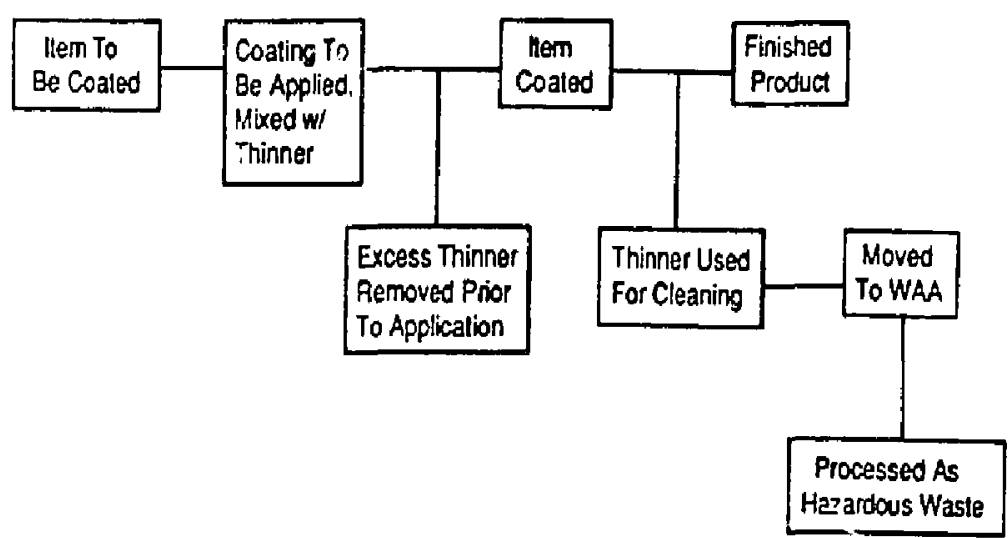

Total pounds per year $-7,700$ 


\section{Attachment 5. Plant Englneering Classifted}

Waste Paper and Asbestos Abatement

Flowsheets 


\section{CLASSIFIED WASTE PAPER, SOURCE - HAMMERMILL}

Classified waste paper is picked up throughout the Laboratory on a daily basis. This waste is transported to the central hammermill where it is shredded, compressed and bagged. The bales are then sold to outside vendors for recycling.

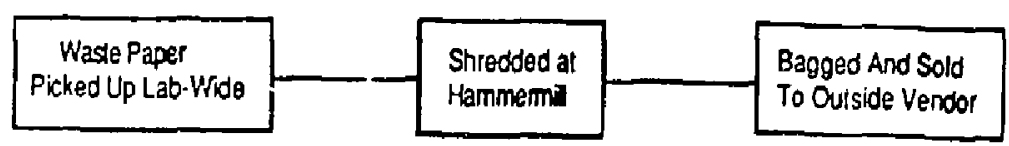

Tolal pounda per year $-500,000$ 


\section{ASBESTOS, SOURCE - LABORATORY WIDE}

Plant Engineering has been involved in incidantal asbestos abatement for many years. The material removed from damaged pipe lagging and other asbestos containing lierms are bagged at the worksite and transported to a WAA.

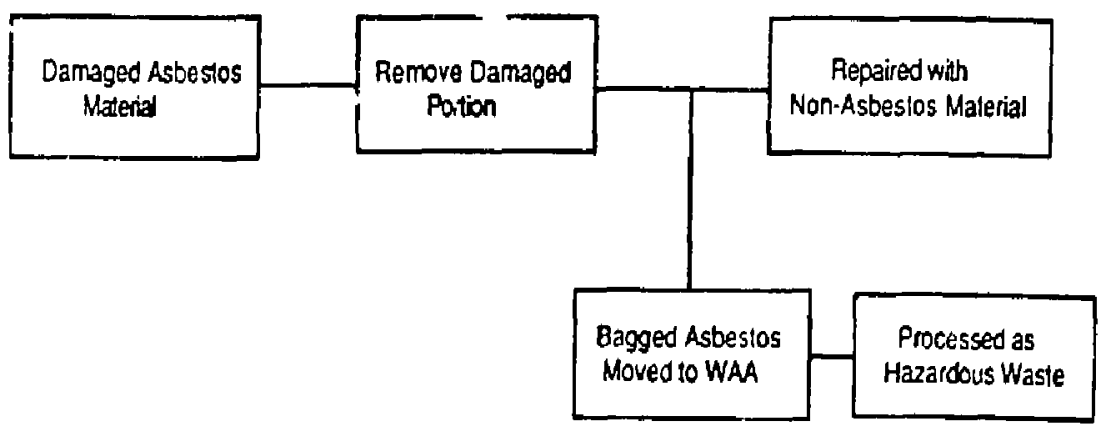

Total pounds per year - 2,750 


\section{DIRECTORATE MINI PLAN}

$$
\text { for }
$$

BEAM RESEARCH AND MFE 


\title{
HAZARDOUS WASTE MINIMIZATION MINIPLAN
}

\author{
Beam Research Program \\ Magnetic Fusion Energy Program
}

Prepared by

Stephen M. Hibbs

Samuel F. Eccles

January, 1990 


\section{HAZARDOUS WASTE MINIMIZATION MINIPLAN}

Beam Research and Magnetic Fusion Energy Programs

\section{INTRODUCTION}

The Beam Rerearch (BR) and Magnetic Fusion Energy (MFE) Programs are engaged in research leading to applications of charged-particle beams and of magnetically-confined fusion reactions. They comprise a single Programmatic directorate and are historically connected, the Beam Research Program originating as an offshoot of MFE. They continue to share many buildings and support resources.

Both conventional and technical facilities vary greatly in age. Most office buildings and light laboratory spaces are 10 years old or less, while most of the major technical buildings are 30 to 40 years old, and include the oldest laboratory building at the Livermore site. The experimental machines and support equipment are from 1 to 15 years old. The Programs' electrical energy capacity requirerzents are larger than those of the rest of the Laboratory combined, so we have a very large collection of heavy electrical equipment that ranges from 10 to more than 30 years old.

Research in the BR and MFE Programs is characteristically performed using a few very large experimental machines with relatively long service lives. Two generic kinds of hazardous waste streams result. Operation and support of these machines generate small but continuous hazardous waste streams. Decommissioning an experiment at the end of its life happens infrequently, but may generate a large amount of hazardous waste in a relatively short time.

The BR and MFE Programs are treated in this Miniplan as a single waste source because their hazardous waste streams are generated in common support facilities and are collected at a single waste accumulation area.

This Miniplan is confined in its geographic scope to the BR/MFE complex outlined in Figure 1 (Site Map) and to the Advanced Te:t Accelerator (ATA) facility at Site 300, Figure 2. 
When the ATA operated at its full electrun beam energy of 50 $\mathrm{MeV}$, radioactive nuclides were created. The bulk of the resulting radioactive waste is in the form of activared aluminum. This radioactive waste has been safely stored in controlled areas set aside for this purpose at Site 300 Aftet a few years, it will decay to non-hazardous leveis and will be disposed of as ordinary waste. We do not project further radioactive waste production a: ATA in the foresieab': future, and neither the BR nor the MFE Program currently generate any other radioactive waste streams. This Miniplan therefore confines itself to discussion of hazardous waste, and does not address radioactive waste or non-hazardous waste.

\section{MANAGEMENT BY THE PROGRAM}

The Director of LLNL has committed the Laboratory to a policy of hazardous waste minimization. In this Miniplan, the BR and MFE Programs commit to a real reduction in their flow of hazardous waste. The Associate Director (AD) for Beam Research and Magnetic Fusion Energy is responsible for this reduction of waste generation by the Programs. The $A D$ has appointed a representative to serve on the LLNL Waste Minimization Steering Committee, and the position of Waste Reduction Coordinator ic the Programs has been created.

Responsibility for hazardous waste minimization is delegated fiom the $A D$ to supervisors and to pegpte responsible- for the experiments. Each experimen!al prografa's Lead Experimenter is reponsible fict assessing the hazardous products of his or her experimest, and for adopting alternatives, consistent with scientific objectives, that will reduce them. The supervisors of machine shops and assembly areas that support experimental programs have the responsibility for assessing their waste streams and, with approypriate management people, determine which alternate processes will reduce the hazardous waste products. These managers are responsible for motivating their employees to implement the measures selected.

A waste reduction oversight group will be formed th oversee the Programs' waste streams, consider and propose alternatives that will reduce waste, and help motivate employees to implement waste minimization measures selected and approved 
by Programmatic managers. The members will include the Programs' Waste Reduction Coordinator, the AD's representative to the LLNL Waste Reduction Steering Committee, and one representative each from the $B R$ and MFE Programs, from the matrixed engineering disciplines, and from the local Hazards Control team.

Personnel affected by nèw!y adoptrd waste minimization processes will be trained in their implementation. This training will be in the form of clasies given either by the Programs themselves or by the Hazards Control and Environmental Protection departments.

Once trained, all personnel will be accountable to the $A D$ for implementation of the LLNL Waste Minimization Program Pian.

\section{CHARACTERIZATION OF BRAMFE WASTF STREAMS}

These Programs generate two characteristic kinds of hazardous waste streams:

1. A more-or-less continuous flow of waste results from operating their experimental machines and from support operations. Of the support areas, the local area machine shop is the dominant contributor. Its waste output varies greatly and depends on whether the experimental machipes are operating (small output) or are shut down for modification (larger output). These waste streams lend themselves to minimization, and will bo identified hereafter simply as "operational" hazardous waste.

2. Infrequent but massive amounts of wasle may be created when a major experimental machine and/or conventional facility is demolished or undergoes a major reconfiguration. These waste loads are not subject tc minimization, and will be identified hereafter as "one-time" hazardous waste. These machines and facilities were built long before there was concern with waste minimization and before some materials used in their construction were known to be hazardous. Also, we are uncertain when they will be decommissioned. As these facilities are dismantled or modified, w'e will deal immediately with all the waste material we encounter regardless of kind or amount. 
Contents of the operational waste streams:

The LLNL Hazardous Waste Management (HWM) Waste Disposal database shows that the MFE and BR operational waste streams bave historically consisted of:

- Oils - cutting oils from machine shop operations (declining usage) and hydrocarbon vacuum pump oils (synthetic oils are very expensive and have always been recycled)

- Soivents use for degreasing and incidental cleaning

- Fluorocarbon dielectric contant from operation of induction linear accelerators

- Copper sulfate from accelerator load resistors

- Oil-filled capacitors and transformers (sometimes with PCB's, but most of these have been disposed of)

- Chips and dust from machining structural laminates made of reinforced resins - fiberglass/epoxy is most prevalent

- Miscellaneous chemicals (unused paint, mercury, etc.)

- Miscellaneous solids (lead, beryllium, fiberglass, etc.)

(The average output of operational hazardous waste disposed of by the BR and MFE Programs in 1989 was on the order of 4 barrels plus 800 pounds of miscellaneous items per month. These averages represent a relatively small operational waste stream.)

The following MFE/BR experimental facilities are currently in oferation. They and their support facilities are currently the sources of the Programs' operational waste streams:

- ETA-II (BR linear induction accelerator)

- MTX (MFE tokamak, sometimes operated in conjunction with ETA-II)

- High Field Test Facility (superconducting magnet research)

- ARC (research in advanced accelerator concepts)

- High Power Test Stand (research in advanced pulsed power sources)

- RACE (Ring ACcelerator Experiment)

- DDT (Davis Diverted Tokamak)

Future changes in research missions will eventually cause these facilities to be modified. This may change the character of their operational hazardous waste streams. 


\section{Expected contents of one-time waste loads}

It is not possible to predict all the hazardous waste that might be discovered when an old experimental machine is disassembled or an old facility decommissioned. A survey of the expected contributions would be prepared shortly before starting such work. At least the following might be expected in sizable quantities:

- Oil-filled electrical switchgear, capacitors, and transformers, some of which might contain dilute PCB's.

- Dielectric cooling systems emplcying fluorocarbon coolants

- Mercury diffusion vacuum pumps

- Oil-filled and mercury-contaminated mechanical vacuum pumps and piping

- Components coated with loosely-bound titanium

- Reinforced resin structural laminates

- Plastic foam insulation of various types

- Asbestos pipe lagging, structural fireproofing, and building siding panels

(A one-time waste load is illustrated by the removal, packaging, and disposal by the MFE Program in December, 1989 of 5,500 PCB-filled capacisors $(330,000$ pounds) at a cost of $\$ 410 \mathrm{k}$.)

MFE/BR facilities that may eventually become sources of large one-time hazardous waste contributions include:

Experimental machines already out of service:

- MFTF-B (demolition)

- MFTF-B ADCPS electrical switchyard (demolition)

- TMX-Upgrade (demolition)

- High Voltage Test Stand (demolition)

Experimental machines still in service:

- MTX (major reconfiguration)

- ATA (Site 300) (major reconfiguration)

- ETA-II (major reconfiguration)

- ARC (major reconfiguration)

- High Power Test Stand (major reconfiguration)

- High Field Tesi Facility (major reconfiguration)

- RACE (major reconfiguration)

- DDT (demolition or major reconfiguration) 


\section{THE BR/MFE PROGRAMS' WASTE REDUCTION GOALS}

The Programs' main objectives are to achieve real reductions, to the extent feasible, in the amount of operational hazardous waste, and to minimize the costs of managing it. To reduce operational tiaste, we will institute the following plan.

In the first year:

The goal of the Programs for the first year this Hazadous Waste Miniplan is in effect will be to determine accurately the volumes, masses, categories, and costs of operational hazardous waste generated, and compute their generation rates as a function of our "Unit of Production". This computation is de:cribed in detail in Section VI. These will be the baselines against which future generation rates and costs will be compared.

In succeeciing years:

The goal will be to reduce the operational waste generation rates per "Unit of Production" at the end of the fifth year by $25 \%$ to $30 \%$ of the baseline rates determined in the first year. Expressing this goal in terms of genetation rates instead of absolute quantities will allow us to demonstrate the effectiveness of our waste reduction efforts even as our waste-generating workload fluctuates. Adoption of this goal insiead of a more ambitious one is supported by operational waste output that is already relatively small, and by the fact that gains are harder to achieve in older facilities like ours. Only our office spaces and a few small technical spaces are less than thirty years old. The major technical buildings are thirty to forty years old, and MFE's Building 431 is the oldest dedicated laboratory building at the Livermore site. Our experimental machines, some of which are not currently operating, range in age from 2 to 15 years.

The measuring system described in Section VI will be used to determine how effectively this goal is being met.

An additional goal in the succeeding years will be 10 reduce the cost recharges due to hazardous waste disposal compared to recharges incurred in the first year, and to avoid offsetting the savings with associated Programmatic administration costs. 
One-time hazardous wastes resulting from demolishing or reconfiguring our old facilities may temporarily overshadow the Programs' operational waste streams. Their timing depend's on the Programs' scientific objectives and funding levels, and cannot be predicted today.

If the main objectives of true waste minimization and of cost reduction are met, then additional benefits should follow, namely, improved compliance with laws and regulations, reduced occupational health and accident risks, improved operating efficiency, and improved relations with the community outside the Laboratory,

\section{METHODS OF MINIMIZING WASTE}

Generally, the principal avenue oper in us for operational waste minimization is 10 seek non-hazardous alternatives to the oils, chemicals, silicon compounds, Freon, and other fluorocarbon compounds presenily used in significant quantities. These $u^{\prime}$ stes can be measured with respect to the "Unit of Production" as outlined in Section VI below.

Improvements in housekeeping practices and disposal of unused equipment should also give us substantial early gains. This activity has already begun in earnest in both Programs.

A recurting contribution to the waste stream is the scheduled replacement of oil in mechanical and turbomolecular vacuum pumps. Synthetic oils have always been recycled. It should be possible to recycle hydrocarbon oils, too, to avoid wasting them. The vendors we buy from are willing to do this on either a purchase order or contract basis.

In these Programs' experimental machines, materials are of ten used far beyond their rated capacities and must often be replaced much sooner than they would be in applications for which they are rated. For example, an electrical breakdown through the fluorocarbon dielectric fluid in an induction linear

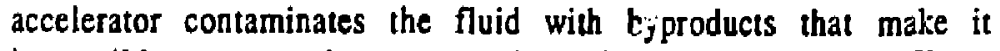
impossible to continue operating the accelerator. Waste minimization cannot be a factor in the decision to replace the fluid. The replaced fluid is likely 10 momentarily dominate the 
Programs' operational waste stream and, like one-time waste, it is irreducible.

It is recognized that the awareness and motivation cf individual employees are the ultimate keys to the success of the LLNL Waste Minimization Plan. Therefore, all personnel working within the $\mathrm{BR}$ and MFE Programs will be provided with current copies of this Miniplan, and other me'bods will be devised and implemented to foster a "minimum-waste culture"

\section{MONITORING WASTE MINIMIZATION}

\section{QUANTIFYING THE OPERATIONAL WASTE STREAMS}

Our method of quantifying the Progjams' existing operational waste streams, both initially and when assessing our reduction efforts, is designed to reflect real gains or losses in our rate of operational hazardous waste production, even as our wasteproducing workload fluctuates. It will work as follows:

When this Miniplan goes into effect: We will divide our operational hazardous waste output, as reported by the Hazardous Waste Management Waste Disposal database, into no more than ten categories, much as they are categorized in Section III. This categorization, while subject to review, will not ordinarily change over time.

On a monthly basis thereafter:

1. Every line item in the database will be assigned to one of the categories described in the preceding paragraph.

2. An Adjusted Total Cost will be computed for the month. Il will serve as the Programs' mandated "Unit of Production". It will consist of the sum of all wage expenses except those for computations and scientists fiom other programs, plus S \& E charges for procurements, stores, contract labor, ME fabrication recharge, administration, and electricity. The intent is to include the costs of activities in the Unit of Production that truly affect the rate of hazardous waste generation and to exclucie those that ciearly do not. These assignments are slightly arbitrary, because som: activities certainly will fall into gray areas, yet the arbitrariness is necessary to keep the computational workload reasonable. 
3. The quantity of each category of operational waste, in pounds or gallons, will be divided by the Programs' Adjusted Total Cosi (Unit of Production) for that month If, for example, our ("Unit of Production") for a month is $\$ 1.0 \mathrm{M}$ and we generate 50 pounds within a given hazardous waste category in that month, the basis for that waste category, B, for comparison with past and future months is

$$
B=\frac{50-\text { Junds }}{\$ 1.0 \mathrm{M}}=5.00 \times 10^{-5} \quad \begin{aligned}
& \text { (units omitted to avoid } \\
& \text { confusion with custs of } \\
& \text { disposal) }
\end{aligned}
$$

Quantifying the one-time waste loads

Records of the one-time hazardous wastes generatid by the demolition or major modification of our facilities, when it occurs, will be kept separate from the monthly computation of operational waste streams. They will be documented, but since they will be irreducible, no statistical analysis or comparison with other waste streams is contemplated.

The Waste Reduction Coordinator will be responsible for collecting the data, performing the calculations described above, and maintaining the data files needed to evaluate and report on the Programs' waste minimization efforts.

The Programmatic oversight group will, over time, target specific major contributors to the Programs' operational waste stream. Intensive efforts will be made to reduce their rate of generation. Opportunities will be sought to minimize these waste products and their costs through materials substitution, changes in the processes that create them, and input to the design of new processes and experimental machines where possible. The waste minimization goals outlined above will form the criteria for selecting targeted materials and processes. The Oversight Group may institute source controls for these materials so that they can be traced through the processes that consume them and so that the fraction that secomes hazardous waste can be identified. 


\section{COSTS OF WASTE HANDLING}

The Laboracory has studied a hazardous waste recharge system for all programmatic generators so as to fully allocate waste disposal costs to the generazors. Ambiguity in Department of Energy funding levels for waste management operations has complicated the Laboratory's plan to implement a cost incentive. based allocation rystem. Alternatives to the initial rechar;e program are currently being studied. One of these alternatives will be implemented at the LLNL after final funding levels are determined, and the BR and MFE Programs will then conform.

\section{LNFORMATION EXCHLANGE}

Sources of ideas for new waste reduction strategies will come from employees, from data bases and informational publications at LLNL, from other DOE laboratories, and from industry. These sources will be monitored by the Programmatic oversight group for new processes and procedures. (Example: investigating ongoing research seeking replacements for chlorofluorocarbons by LI,NL's Atmospheric and Geophysical Sciences Division, reported in The Daily Clips.) Any ne process we devise will be available to LLNL databases. Conferences and workshops will he a major forum for exchange and we would plan to attend these whese appropriate to the Programs.

\section{AUDJTS_AVD EVALUATIONS}

The Programmatic oversight group will review and prepare annual written reporss on the effectiveness of the Programs' waste minimization effort. The reviews will address, as a minimum, progress toward the Programs' waste minimization goal as stated in this Miniplan, compliance with current laws and regulations, the impact of waste minimization procedures on the Programs' scientific and support work, the cost/savings attributable to the waste minimization effort, changes needed in the Miniplan, and recommendations for changes in the LLNL Waste Minimization Plan.

The reports will be distributed to everyone in the Programs who has accountability for execution for a part of this Miniplan, and to the LLNL Waste Minimization Steering Committee. The first report will be dated one year after formal implementation of this Miniplan. One additional informal review will take place six 
months after formal imprlementation of this Miniplan, and the report will be distributed only to Programmatic management.

In addition, the oversight group will be responsible for coordinating audits and responding to inquiries on waste minimization from outside the Programs. 


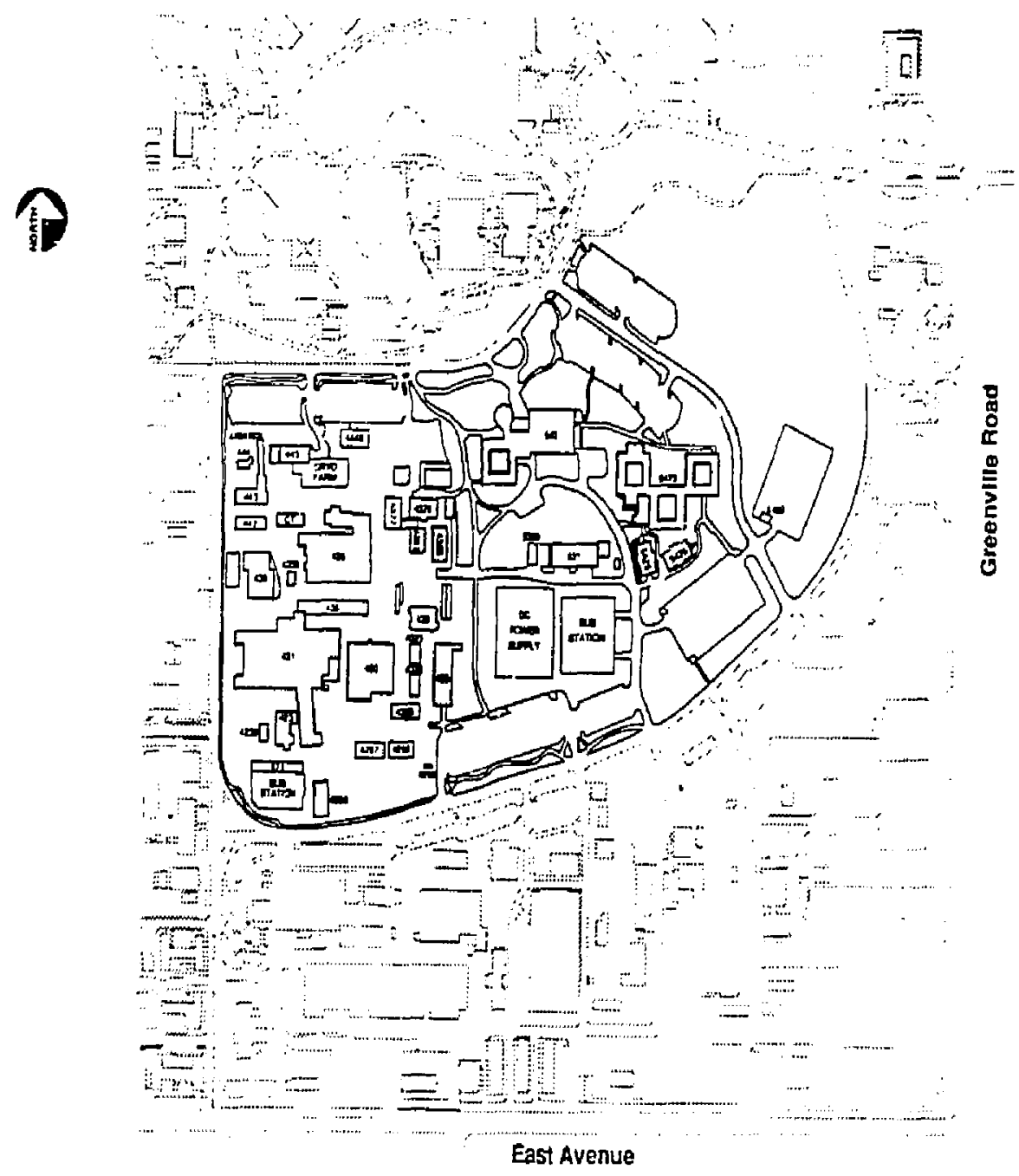

Figure 1. The Beam Research and Magnetic Fusion Energy complex at the LLNL Livermore site 


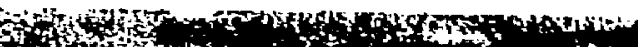

A

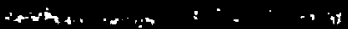

-

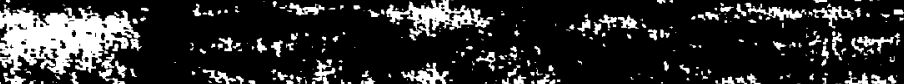

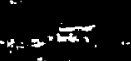

s........

ints:

$\therefore$ and

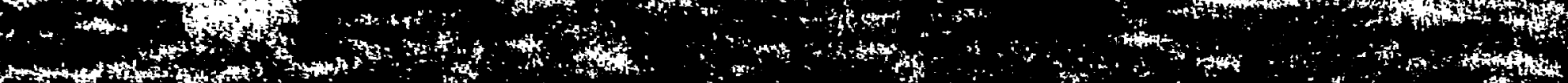

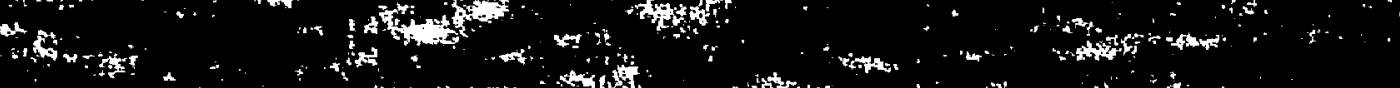

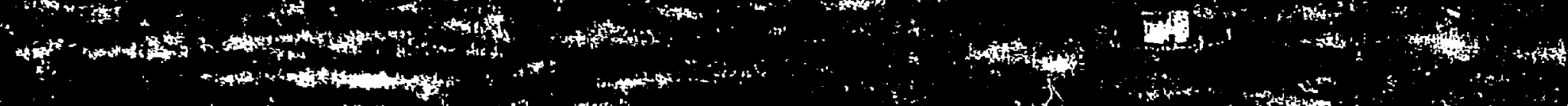

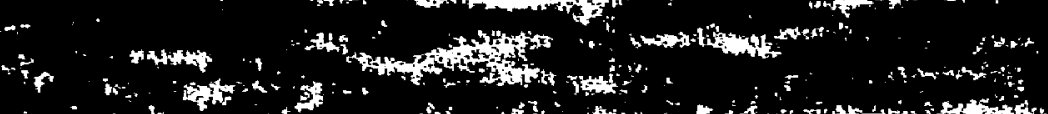

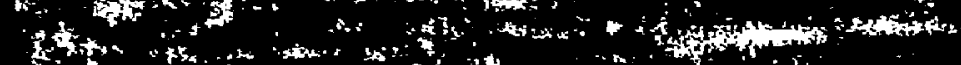

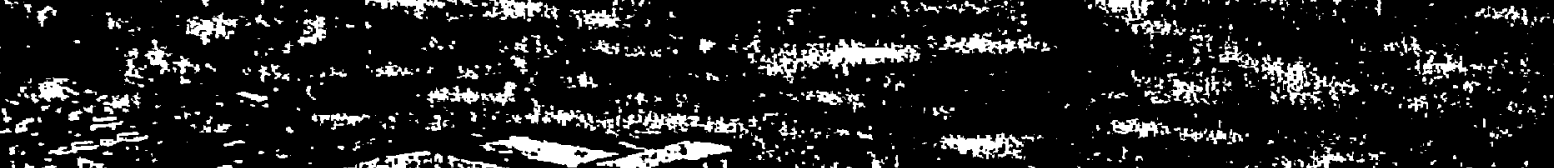
sing

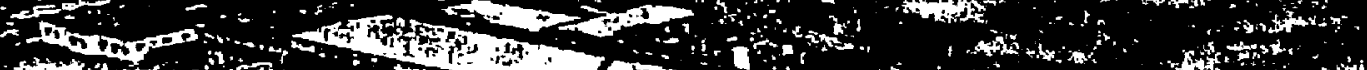

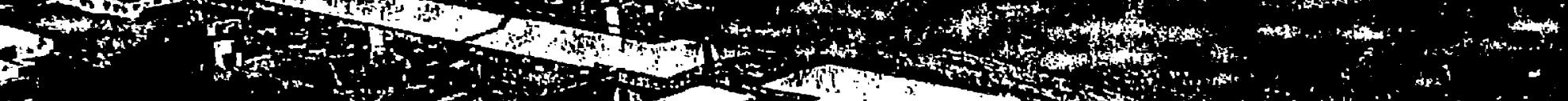

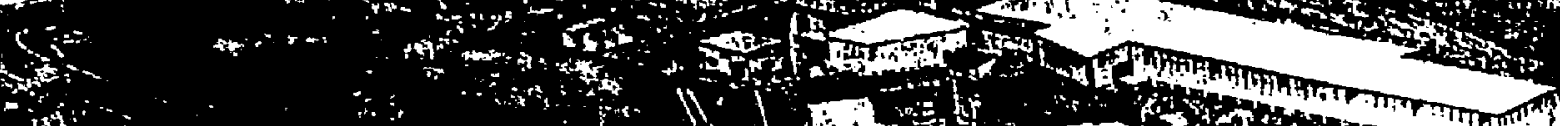

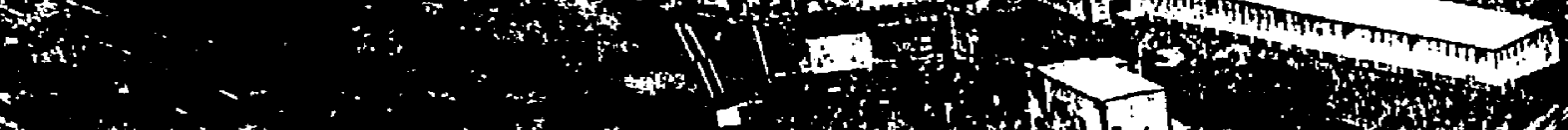

-

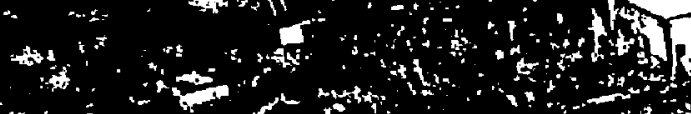

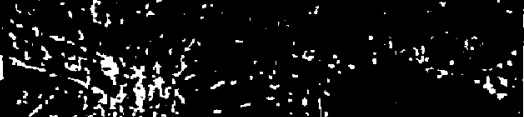

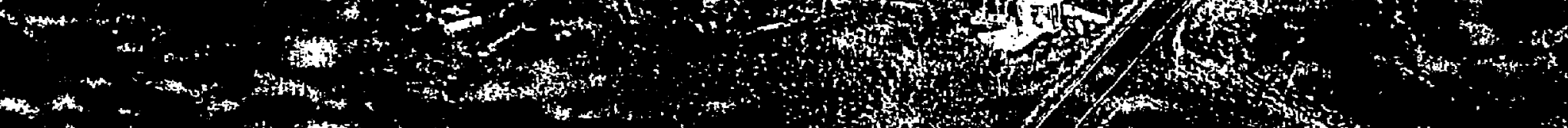

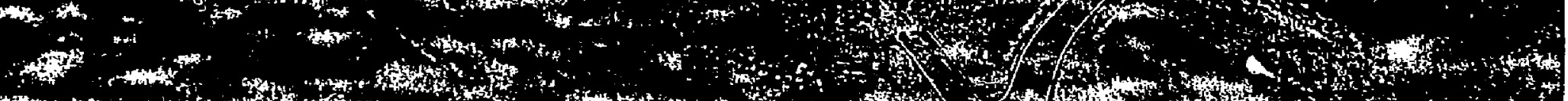

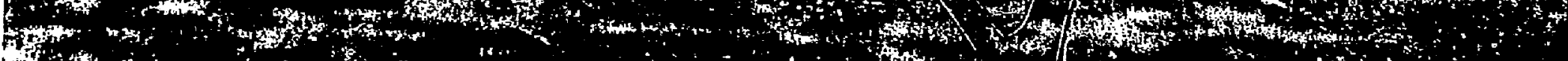
2. Figure 2. The Advanced Test Accelerator (ATA) facility at Site 300 


\section{DIRECTORATE MINI PLAN}

$$
\text { for }
$$

BIOMEDICAL AND ENVIRONMENTAL RESEARCH 


\section{Waste Minimization Plan for the \\ Biomedical and Environmental Sciences Research Program}

September, 1985

The Biomedical and Environmental Sciences Research (BER) Program at Lawrence Livermore! Jational Laboratory, has reviewed its research goals and operations and formulated a plan of action that will allow its staff to contribute to the minimization of wastes produced at LLNL This plan is in keeping with the national priority to redi.. . the amount of hazardous waste produced by our nation and to reduce the impact on the environment of the disposal of wastes that are produced. The approach primarily utilizes procedures established within the BER Program but also relies upon the waste requisition data resources of the Hazardous Waste Management Group. The primary components of the plan, education and administrative controls, will ensure that careful review of the nature and volume of wastes generated in our ongoing research operations occurs on a regular basis, that new operations are carefully scrutinized for waste minimization options, and that successful approaches to waste minimization are shared with all staff io maximize their impact. It is expected that these actions will have the additional benefit of helping to control the costs of waste disposal.

It is intrinsic to our research missions in genetic toxicology, monitoring of emvironmentahexposures, and molecular genetics to work with hazardous chemicals and radiojisotopes. Our operations include many research groups with widely diverse and independent goals. Generation of wastes containing

- toxic materials, radioactive materials, biohazardous materials, and trixtures of these is inevitable. We will work, however, to identify and adopt new practices and new technologies that permit reduction of the amount of waste generated wherever it is safe :0 do so. Many of the elements of this program are already in place.

It will continue to be BER Program policy to make conservative judgements about the hazardous nature of waste generated in our research. Tor example, unless it is directly determined that no toxic materials are present, eulture fluids or other materials exposed to toxic materials will be disposed of with the assumption that the toxic materials are present. Mutagens, carcinogens, and presumptive carcinogens at any concentration will continue to be disposed of as hazardous waste; there is no method to determine the risk of their disposal by other means.

The plan outlined below identifies both administrative controls and educational programs that will help ensure that minimization of waste occurs : then possible and that these efforts are documented. 
THE PLAN

\section{Administrative Controls}

Guidarce Documents: The operations of the BER Program are performed under Facilities Safety Procedures (FSPs) and Operational Safety Procedures (OSPs) developed by the Program with the guidana of the Hazards Control and Environmienid Protection Departments. Wren each of the FSPs comes due for tevision, sections explaining the rationale for mininization of waste production and examples of activities that minimize wa ste or teduce its toxicity, will be incor Jrated. Approval of new OSPs, and renewal of old OSPs, will require that the amount and types of waste generated have been reviewed for minimization and that substitutes for processes or materials have been considered and adopted where possible.

Ordering: Where possible, redundancy, waste and toxicity of chemisals will be reduced. (1) Orders of carcinogens, chemicals whose handling and disposal requise special care, will require confimation that the requested items are not cirrenty available in satisfactory form in our carcinogen handling facilit. These orders curnently are funnelled through one office, so no majur revision of prosedures is required. The log of carcinogens held by the BER Program will be made available to this office. (2) Dur $\mathrm{L}$ - inventories of the BER storeroem, it r ill be determined if there are items that . 'e being discarded due to expiration of useful shelf life. If so, the amount of these items ordered will be reduced. (3) Whenever possible, when less toxic substitutes of stock items become available, they will be substituted, even if these are not available through the Central Supply Department.

Recycling: New users will be sought for surplus chemicals that wruld otherwise become waste. Scientists will be urged to segregate materials that the Laboratory has determined can be recyded.

Audits: Summaries of the wastes produced by each working group, made possible by recovery of data from the Waste Requisition Forms by the Hazardous Waste Management Group, will be shared with thein to alert them to the types and volumes of materials generated. Surcessful methods of reducing either the volume or the toxicity of waste will be shared with each generator so that each may deternine the relevance of these approacies to his/her research program. 


\section{Education}

Individual scientists can have the greatest effect on the amount of waste generated if they are aware of the impact of their actions. It is necessary that they understand the value of reduction of the toxicity of waste generated, of segregation of wastes, as well as the overall reduction of volume of waste. T.ie costs of disposal or treatment of different types of Naste will be distributed to all waste generators. When known, changes in disposal practices that affect the cost of waste disposal will also be shared with BER staff.

There are currently several formal training conduits for explaining and encouraging waste minimization practices: our BEF Program Safety Orientation course (HS92B), offered for scientific staff twice a year, and the Environmental Protection Department courses for waste generators.

In addition, periodic memos are distributed to all our staff that draw atter !'on to new technologies or ploducts whose adoption can lead to reduction of waste.

\section{Summary}

This plan for minimization of waste generation in the Biomedical and Environmental Sciences Research Program will permit the staff and administration of this Program to continue its research on the impact of hazardous agents on man and the environment in a responsible manner. 


\section{DIRECTORATE MINI PLAN}

$$
\text { for }
$$

\section{CHEMISTRY AND MATERIALS SCIENCE}




\section{INTRODUCTION}

The "Hazardous and Solid Haste Amendments of 1984" have increased the difficulty and expense of disposal of hazardous wastes. Some wastes, such as liquids and ext:;emely toxic substances are now banned fron land disposal, the conventional method of disposal used by industries for hazardous waste disposal. Inadequate containment of wastes after disposal has resulted in contamination of air, water, and land resources. In response to a number of highly publicized incidents (e.g., Love Canal and Times Beach), Congress has passed new laws resulting in the closure of many disposal sites. California previously had eleven disposal sites; now it has one.

Congress has mandated that waste production be minimized and that whatever waste cannot be eliminated be disposed of in a safe manner. Waste minimization has long been a goal of congressional action. The "Federal Water Pollution Control Act of $1972 "$ set a gool of zero discharge of wastes to the nation's waters by 1985 . The ritle of the original hazardous waste legislation, "Resource Conservation and Recovery Act of 1976" [RCRA] was cast in terms of reducing wastes rather than disposal of wastes. In the "Hazardous and Solid Waste Amendments [HSWA]" :O RCRA in 1986, Congress stared it's policy clearly:

"The Congress hereby declares that it is the policy of the United States that, where feasible, the generation of hazardous waste is to be reduced or eliminated as expeditiously as possible. Waste nonetheless generated should be treated, stored, or disposed of so as to minimize the present and future threat to human health and the environment. And that the proposed method of treatment, storage, or disposal will winimize the present and future threat to human health and the environment." [RCRA section 1003 (b) as anended by HSWA PL 98-616, Nov. 1984]

It is required by legislation that waste generators certify that they have in place a plan to minimize waste generition. Until the publication in the Federal Register [June 12, 1989, vol 54, no. 111) by the Environmental Frotection Agency of "Draft Guidance to Hazardous Waste Generators on the Elewents of a Waste Minimization Program", there tas no clear indication of what level of program would be considered to satisfy the intent of the legislation. Prior to the publication of the EPA draft guidance, the Department of Energy had defined waste minimization as any "action that minimizes the volume or toxicity of waste by: (1) avoiding its generation, or (2) recycling". Waste reduction was defined as "waste ainimization plus any waste treatment that reduces volume or toxicity of waste requiring disposal". (DOE memo from T. E. Wade, acting assistant secretary for Defense Programs dated oct. 20, 1988, and presentation materials used by $J$. Mathur, DP-12, in June, 1989).

Cost reduction provides a strong additional incentive to minimize wastes. Over the past several years, prices for disposal of liquid vastes have increased by nearly an order of magnitude; current costs average $\$ 20$ to $\$ 25$ per gallon, depending on the exact 
type of waste. In the euture, all 11 guld wastes will have to be trested and rendered into solid form prlor to dispoeal. The costs of waste treatwent and disposal now need to be factored into any experimental pian. Another cost that needs to be considerad in the generation of buste is the time consitments required for waste disposal. The person generating the waite wust provide a waste requisition form describing the nature of the vaste prior to shiprent for disposal. In the Chemistry and Materials Science Department, the waste generator is also responsible for packaging of the waste.

WASTE MINIMIZATION PIAN FOR CHEMISTRY \& MATERIALS SCIENCE DEPARTMENT

There are several key elements that need to be included in a waste minimization plan. These elements are

1. Establishing the inventory of wastes generated.

2. Establishing methods of control for unintentional waste generation, e.g., by control of chemical stocks.

3. Factoring waste vinimization into experiment and process design.

4. Ensuring proper segregation of wastes and recycling wastes where appropriate.

5. Training of personnel to ensure that waste minimization concepts are understood.

In the Chemistry and Kiterials science Department, the tajority of activities that generate wastes involve the use of chemical reagents and solvents in individual research and analytical laboratories. Conseguently, our waste minimization plan will focus on control of chemical inventory and usage.

The first stage of our prograw will be an inventory of waste generation by each laboratory and an inventory of chemicals held by each laboratory. The information gathered by this inventory will be entered into a computer data base for use in tracking future chemical purchases and waste generation.

A central control system will be established for purchase of hazardous or toxic chemicals. Data related to purchase and subsequent disposal of vastes resulting from usage of these chemicals will be entered into the central data base. When a request to purchase a hazidilous or toxic chemical is received, the inventory control clerk-will determine whether a source of the substance already exists in the Department stocks. If such a source exists, the requestor vill flrst be directed to the existing stock prior to authorization of purchase of new stock. The central

- data base will also track disposal cost for wastes from each laboratory.

Hastes generated in the laboratory will be placed in prelabelled containers. Every effort will be made to segregate non-hazardous wastes from hazardous wastes, and to avold the 
generation of mixed radlosctive/hazardous wastes caused by improper disposal pracedures.

Periodic inspections vill be conducted to ensure that waste minimization and waste disposal requirements are being tollowed.

Laboratory personnel will receive training in the principles of waste minimization and the requirements for handling and disposal of hazardous and toxic wastes, and of radioactive wastes, where appropriate.

All bench top and pilot-scale experimental simulations that represent new procedures and involve chenical usage will require a form: : experimental plan that lists reagent u: age and expected waste generation. For those experiments expected to generate more than ten (10) gallons of liquid waste or twenty (20) pounds of solid waste, or ten (10) pounds of solid or one (1) gallon of liquid extremely [accutely) hazardous waste, or which have the potential for exceeding allowable air enission standards, the plan vill establish whether

a. the specified volumes and types of reagents are necessary:

b. the waste by-products are amenable to reduction in volume and/or toxicity;

c. the design has been optimi:ad so that unnecessary waste generation is avoided;

d. all ancillary systeys are considered with respect to pollution abatement, equipment contamination, and energy and water conservation;

e. in cases involving radioactive material, each low level waste generator has established methods to separate non-radioactive waste from low-level radioactive waste $t$ facilitate cost-effective treatment and disposal.

We believe that the plan outlined above, when implewented, will lead to minimization of waste generation in the Chemistry and Materials science Department. The plan involves commitment by management to inventory controls and to oversight, while retaining a high level of awareness and responsibility for waste minimization at the level of the laboratory scientist.

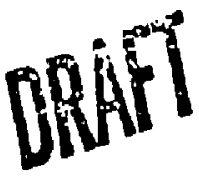




\section{DIRECTORATE MINI PLAN}

for

COMPUTATIONS 
The E. 6 orocess is a color reyersal process, It is also a semi-automated process. This process requires seven differen-chemicals 10 produce color slides and motion pictures. Of these seven chemicals, three ata de-silvered and along with the other four flushed to the Lab sewage system. During the making of this minimization survey, we discovered a way to generale less waste and still produce a quality product. We made adjusments to our processing equipment and chernieals replenishunent. We found that the E-6 process was highly adaptable to changes in the process. If lends jiself well to waste reduction with minimum deficiency in the hue, conorast and overall colos rendition of the film produet We were able to reduce our waste by one half. We accomplished this by mixing only the amount of chemicals that can be used in a nwo week period. Two weets is the life span of most of the chemicals in this process. We replenish the solutions only when replenishment is necessary. This process is plotted on a graphic display chant and is controlled and moritored by a computet.

The hard copy negative (conventional) process is also a semi-automated process. This process contains two chemicals (developer and fixer). The fixer is de-silvered and along with the developer flushed to the Lab sewage system. This process is a low volume replenisher. Because of the nature of the process (rwo step), very litele seplenishment is required. This is also a very low volume user. However, we have made a one third reduction in replenishment rates. Due to the low volume of use, any lesser amount of $\pi$ plenishment will cause the cherricals to die off and increase our total usage.

Opoions. To funthec reduce chemical usage and waste.

1. Dry process (no Chemicals) Laser prine

2. Negarive process (uses unly two chemicals).

3. Negarive process with Vesicular reversal.

4. Trade in com units XCs for XIs eliminates five (5) cherricals

5. Black and Whice reversal process. Five (\$) cherricals

6. Close down Com-unis, use only FR80s, eliminate five (5) chemicals.

\section{EVALUATION AND FEASTRITY OF OPTIONS}

1. The dry process can be used fos alpha-nurieric com, provided quality and storage for less than six months wo one year -is weceptable in the end product The dy process is nocacceptable fior gephics or archival quality for the following reasons: To obtain the required tones aud shades of gray in a gaphic teproduccion, a flom must be able to recad a minimm of 150 line pais per inch. The very best a dry process can do is $50-60$ line pairs per inch. To achieve urebival quality, a product must te prepared and processed to las 50 -100 years. The maximum life spar of the laser dry yrocess is six months to one year, deperding on bow is is stored Given the lack of precise definition, and the short stonge life time of this product, we believe our users would find it unacepiable.

2. The negarive orocess has is adyanmges and disadyanares. The advanmes are: We con coully eliminate ten chemical and use only roo. It is totally accepable for alpha-numeric and graphic outpul If will record the required Iso line pairs per inch. It will recond the required tones and shades of ery. It meets the required archivil quality and stange period of $50-100$ yeas.

The disadyanages ar: Black letters of objects on a while background This will cause eye strain on the user, because there is nouhing to block the brigh back pound light This is why the reyersalomocess is used). The three XC Com units will have so be replaced with three XI Com-unirs. The phow lab will have wo cithes re-model, of rẹplace rwo film processors. The 
diazo Fiche duplicator will have to be replaced with a Vesicular model. This rype of ourput is incended for Hardcopy ouput. making pnints from the ongunal Negarive, not for direst viewing for long periods of time. This option is very costly and would produce a lengthy perturbacion in our ability to process ouput There's some question about the produces' acceptability.

3. The negarive process with vesicular duplication reversal is the mating of the dry and neganive process. This process creates the illusion of a reversal process. It uses the negadve master to reproduce a seemingly reversal product. It brings with it all of the disadvantage of the dry process. and none of the advasuges of the negadive process. There is a built in nienry pertenl image degradation. This product is not suited for microfilaing, if the end product is used for research and archival qualioies.

4. Replace Com units XCs for XILs. The XC Com unit has a buile in film processor that uses five chemicals (AutoPos 2000 process) to process the microfilm outpuc. The XI. Com unit comes with a Camera, take-up, and supply magazines, using the same configuracion as the FR80s. The film from the XLs can then be processed in the Photo Lab using the mictofilm teversal process. This will cotally eliminate five chemicals from the inventory. This is, and probably will be, the most expensive way to eliminate five chemicals from the inventory. We curendy have three XC Com units on hand. This option would increase the amount of waste from the Phoro Lab Black and White processors.

5. Continue with Black and Whire Revecal Process, It is the ideal process for a mictofilm end product. It has the advantages of a silver base image, very good resolving power, good resolution, the inherens ability to record fine cetails in tones. and shades of gray. If can concedy recond 150-300 line pairs per inch, It it very good for long term viewing. It meets or surpasses archive requirements for quality, and long term storage. This process has one disadvantage: one of the chemicals used in the process is Sodium Dichromate. We must collect this chemical and send it off site for treatment We are currenty using approximady fifty gallons per monih.

Couse town the XC Comunits and use only the FR8Os. The work load over the past year has not out paced the ability of the FR80s to handle the load. This has not always been the sinuacion in the past, but it has been the situation for the past year. Closing down the Com units will have no effect on the user community in receiving their output in a timely manner. The advankage to this move, will be the total elimination of five chemicals from the inventory. The disadvantage is the inability of the FR80s to handle the wortload should it renum to previous levels.

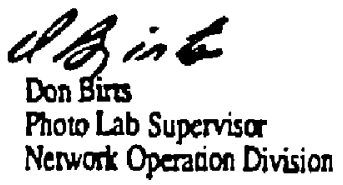

ce: P. Du Bois

C. Kuntes

S. Mendicino 


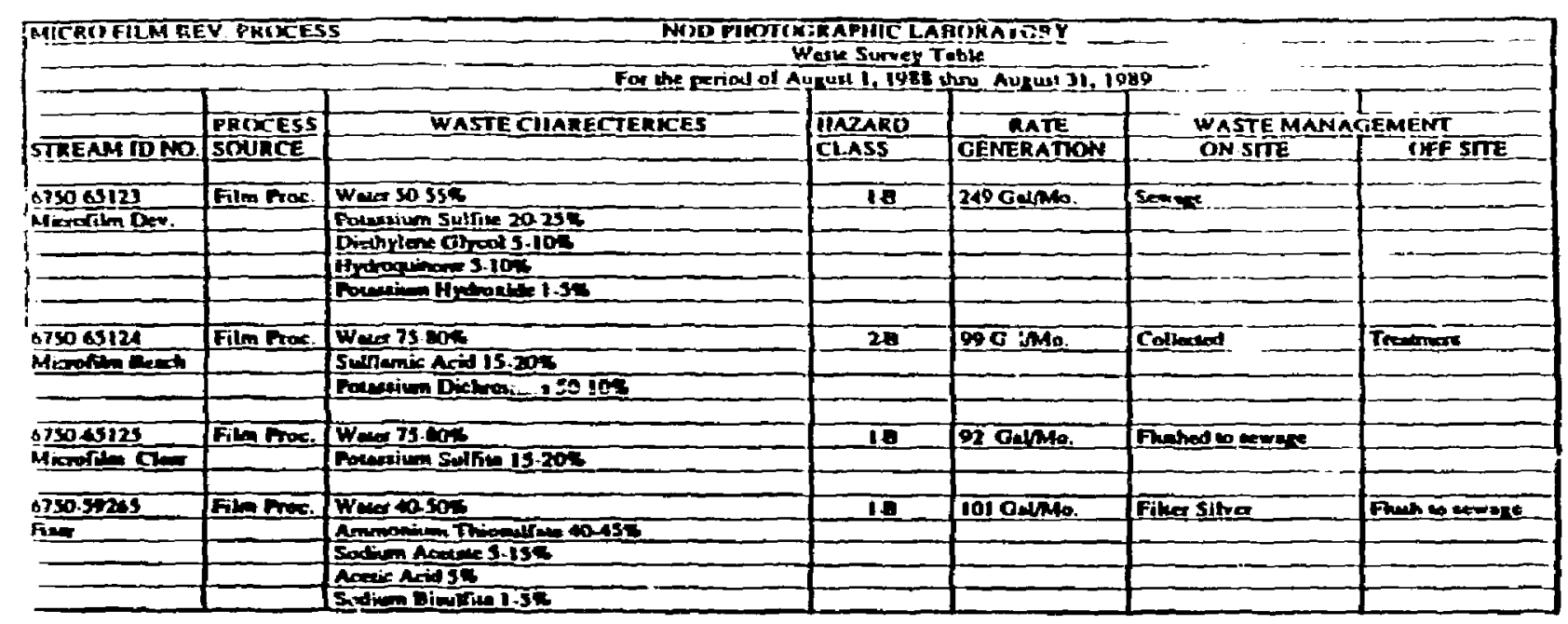




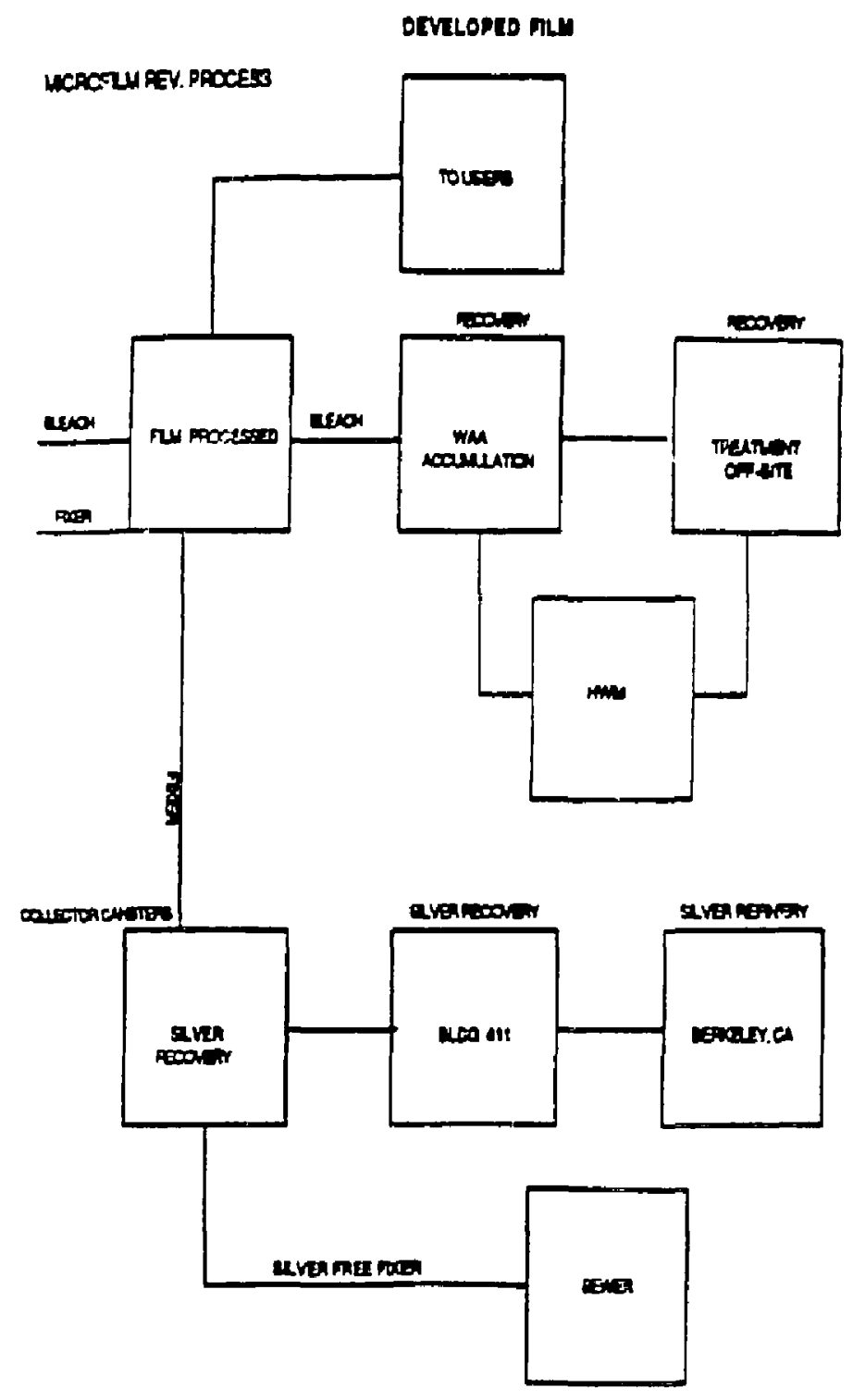

0

0

0

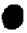

-

-

○

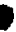

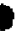

20.5 


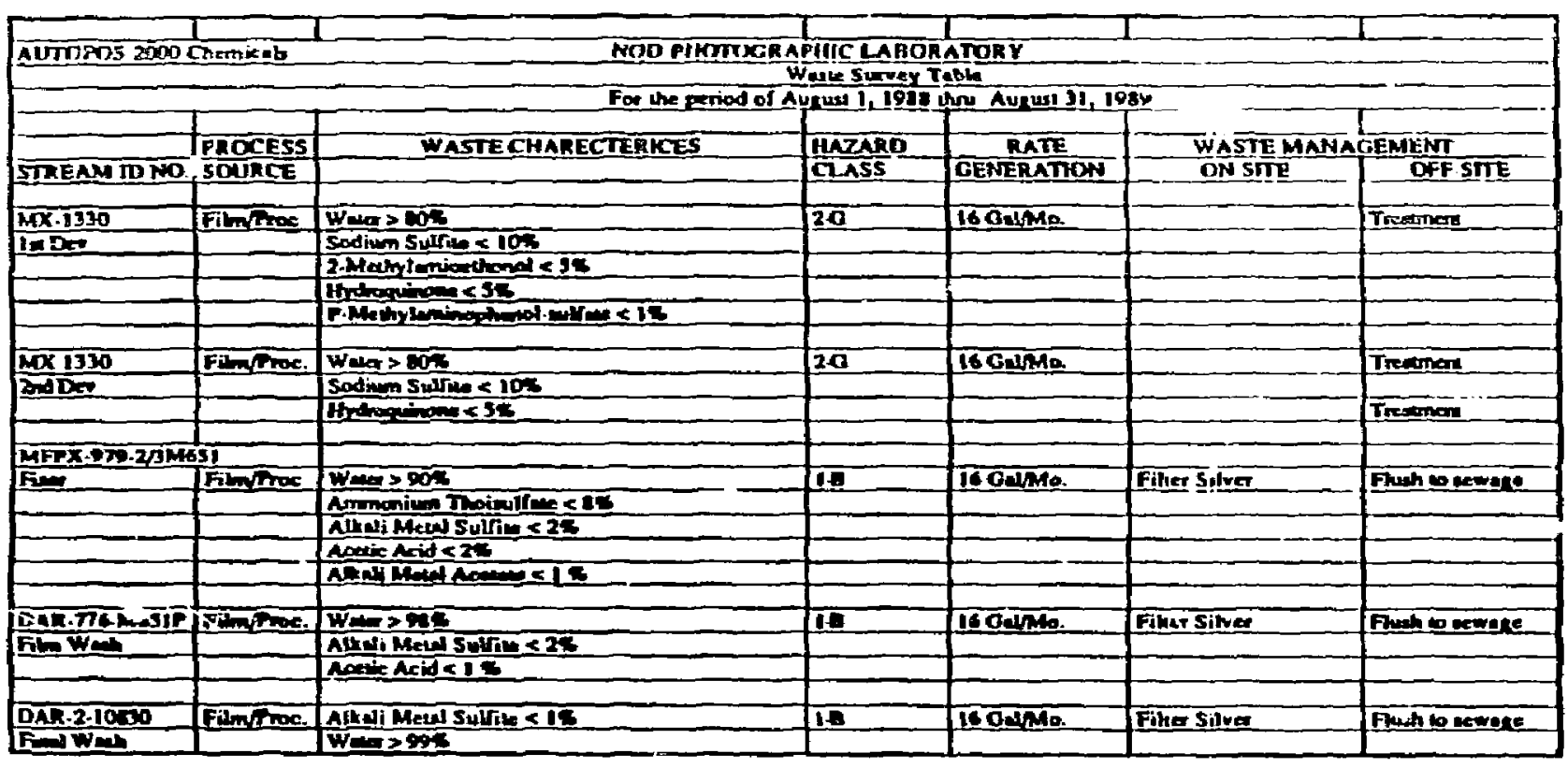




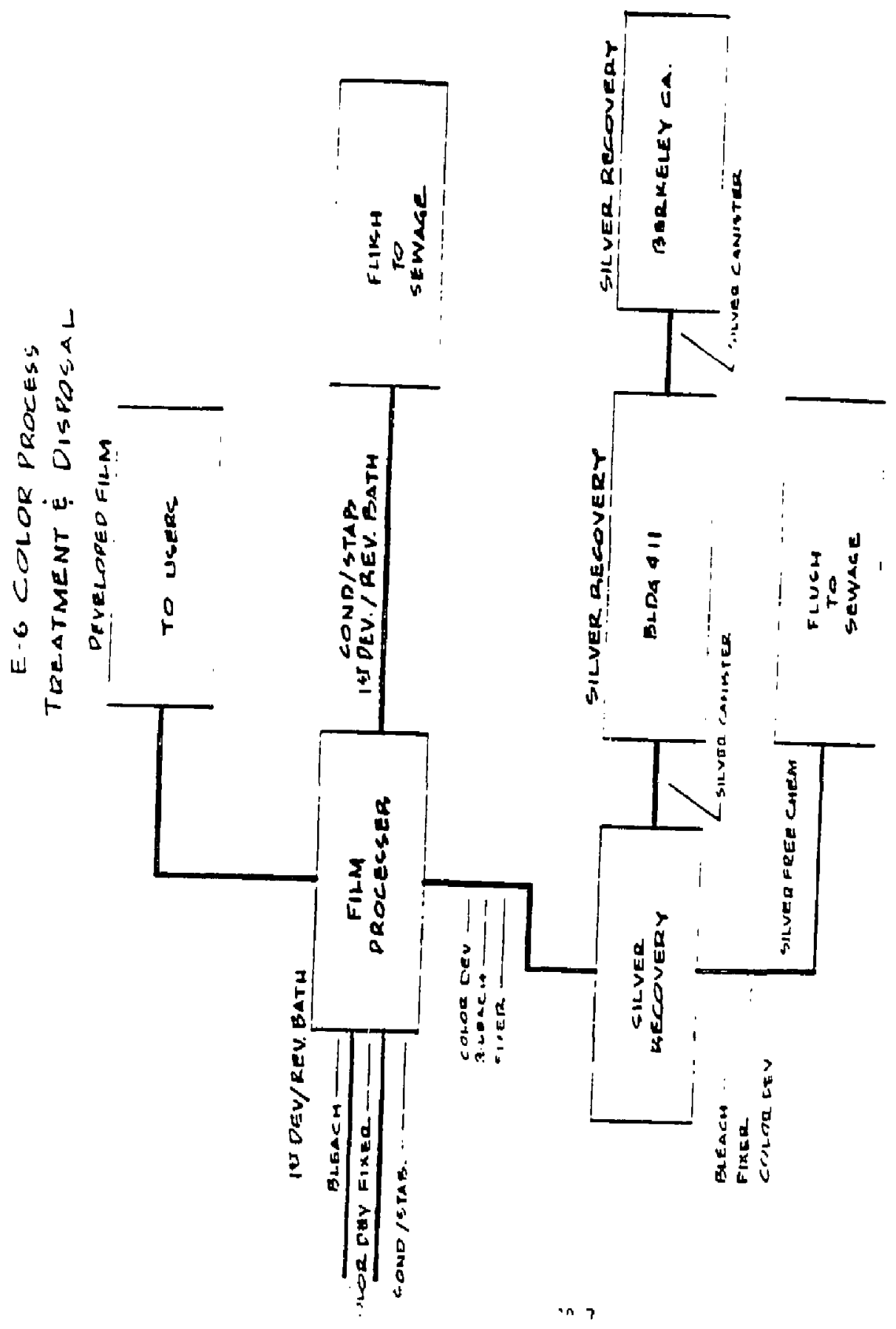




\begin{tabular}{|c|c|c|c|c|c|c|}
\hline \multicolumn{7}{|c|}{ HARDCOPY CHERICALS NEGATVE PROCES } \\
\hline \multicolumn{7}{|c|}{ Fo! the period of Augus! 1. 1948 uru Auguil 31. 1989} \\
\hline STREAMID NOE & SOURCE & & CLASS & RATE & ON STE & OFF.STE \\
\hline$\frac{169.3956}{190000}$ & Fimpros: & 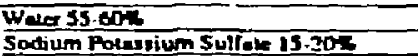 & 28 & 33 onlono. & 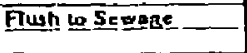 & \\
\hline & & Dicthylo Glyoed $1.10 \%$ & & & & \\
\hline & & 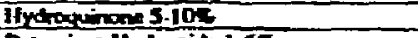 & & & & \\
\hline & & 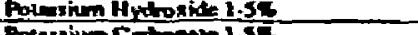 & & & & \\
\hline & & Pocuming $\mathrm{C}$ - & & & & \\
\hline 197.3201 & Fitm proc. & Wex 65.752 & IE & $12.3 \mathrm{Gl}$ Mo. & De silva & Pluh now ore \\
\hline Rrid Fang & & Aluminum nulfue 10.203 & & & & \\
\hline & & & & & & \\
\hline 186.6342 & Filnproe & Wea 40.50 & 18 & $12.5 \mathrm{Gl} / \mathrm{Mo}$ & De silve & Flush beswere \\
\hline Rpidfine:A & & Ammoniun Thionulfow $40.50 \mathrm{~m}$ & & & & \\
\hline & & Bonic exid < $5 x$ & & & & \\
\hline
\end{tabular}


U

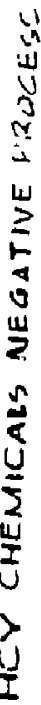

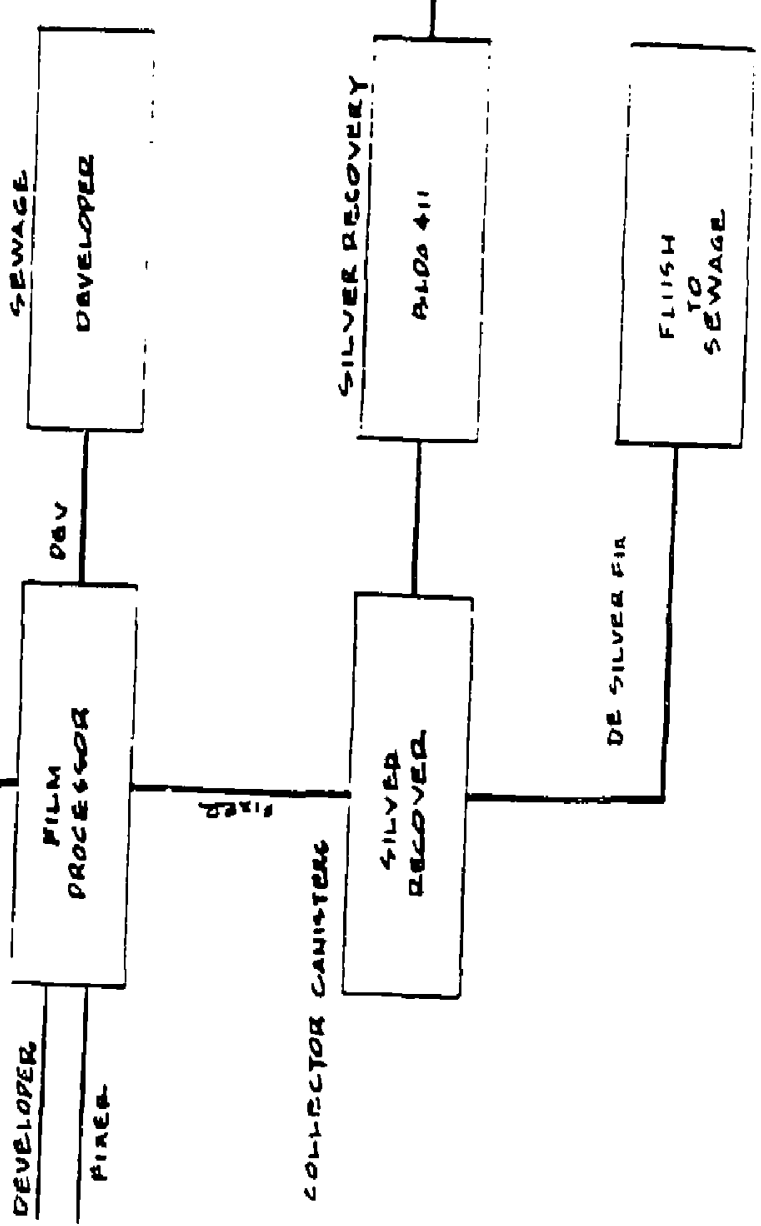

0

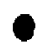

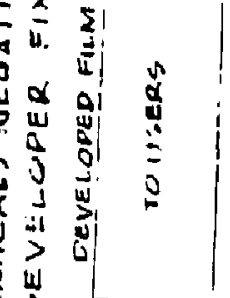

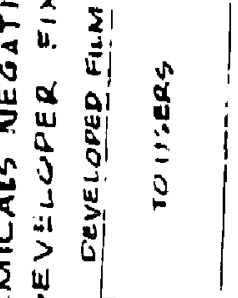

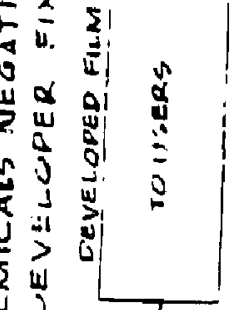

4.

01
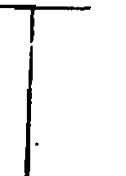
DIRECTORATE MINI PLAN

for

ENERGY PROGRAM/EARTH SCIENCES 


\title{
DRAFT
}

\author{
WASTE MINIMIZATION PLAN FOR THE \\ ENETGY PROGRAMEARTH SCIENCES DEPARTMENT
}

The Energy Program/Earth Sciences Department has identified three locations within their area where waste is generated - Building 243 (the machine shop areas, the laboratories, and the High-Pressure Testing Facilities), Trailer 1402 (Rm. 1003 Dark Rosm); and Building 410.

\section{CHEMICALS USER:}

Building 243 - Chemicals used are acetone, aicohol (methanol, ethanol, isopropyl), toluene, methyl ethyl kelone, trichloroethylene, trichloroethane, carbon tetrachloride, and kerosene. There are numerous reagent grade chemicals used and stored in the building. Presently they are - hydrofluoric, hydrochloric, and nitric acids. acetic acid, sodium hydroxide, iodine, bromine, and salts. Cutting fluids/oils used are sulfur based cutting oil, A-9 aluminum cutting fluid, Cool Tool cutting fluid, and Trimsol water soluble oil in a 40:1 mix. Isopar-H, hydraulic fluid, and mechanical pump oils are also used.

Trailer :402 Dark Room - Photographic chemicals (activators/ developers).

Building 410 . Solvents are used to clean and recover product material from equipment used in retorting at the oil shale retort lacility.

\section{WASTE GENERATED:}

Builoing 243 - Chlorinated and non-chlorinated solvents, non PCB oils, analytical reagent chemicals, paper wipes and cloth rags contaminated with oils, solvents and chemicals. Also, photographic developer, fixer solutions and waste paper are periodically generated from a darkroom (Rm. 2004A) in this building. 


\section{DRAFT}

T1402 Dark Room - photographic developer, fixer solutions and waste paper accumulated from the photographic work.

Building 410 - was' $\rightarrow$ solvent, cloth rags and paper wipes, filter'ig materials that is contaminated with the product oil and/or other material.

\section{WASTE HANDLING AND MUIIIMIZATION:}

All storage of chlorinated and non-chlorinated solvents, cutting fluids and oils, and all waste products from them, are kept to a maximum of 5 gallons and are stored in an approved safely dispenser or container in an approved containment structure. All waste products have their own individual containers to eliminate waste mixing. All waste contaminated with a chemical, solvent or any substance that is considered to be hazardous to the environment is handled as hazardous waste and is disposed of as hazardous waste.

We will be moving the dark room in T1403 into Building 243's dark room. Combining these two areas into one location will reduce chemical usage, storage and waste.

Of the twenty-one machine tools in the machine shop areas, seven machines have coolant recovery systems, seven machines are not equipped with recovery systems, and seven do not require such systems. The seven machine tools that have coolant recovery systems use a water soluble oil solution for cutting. The fluid is recovered and used again - creating little or no waste. The seven machine tools not equipped with recovery systems are specialized milling machines or small lathes where small amounts or no cutting fluid is used. These machines will be fitted with coolant recovery systems in future upgrades to minimize some cloth and paper waste. All other machines do not require coolant for their operation or require special coolant applications (grinders, band saws, drill presses, sanders).

Installing coolant recovery systems on all machines will reduce the need for different types of cutting fluids, thereby reducing our generation of waste. This will be addressed in future upgrades. 


\section{DRAFT}

In the High-Pressure Testing area the largest waste is hydraulic oil (used in the presses and vessels during testing) and cloth and paper wipes (used to clean equipment and spills). Plans for waste reduction are to send the oil for reclamation, and use launderable cloth rags to eliminate the usage of paper and cloth wipes.

\section{SUMMARY:}

The wasie generated in Building 243 is small and poses minor problems. Personisl in Energy Programs and Earth Sciences Cepartment will be made aware of the proper handling for all types of wastes. They will be responsible for all waste generated from their lob assignments and will be responsible for prompt, correct handling and disposal procedures. This will be achieved through employee education and awareness. 


\section{DIRECTORATE MINI PLAN}

$$
\text { for }
$$

\section{ENGINEERING}


WMP 343

January 1990

\section{WASTE}

\section{MINIMIZATION}

\section{PLAN}

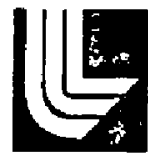

High Pressure Laboratory Building 343

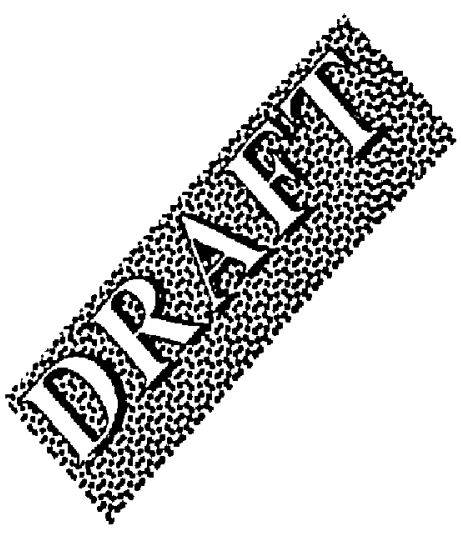

LAWRENCE LIVERMORE NATIONAL LABORATORY University of California/Uvermore, California 


\section{CONTENTS}

\section{Page}

1. Objective

2. General Description of Facility Activities

3. Applicable Documents

4. Training and Awareness

5. Waste Generation Identification

๔. Current Waste Minimization Practices

7. Future Waste Minimization Practices

8. Tracking, Reporting and Review 
Objective:

This plan has been prepared and will be actively pursued to minimize the generation and disposal of waste by products and, in particular, hazardous or potentially hazardous waste in and around the High Pressure Laboratory. The objective is to abide by all policies, rules and regulations applicable to the Laboratory and to environmental, heath and safety policy statements issued by the Laboratorv Director and the Associate Director of Engineering.

\section{G. .eral Description of Facility Activities}

The High Pressure Laboratory at the Lawrence Livermore National Laboratory is primarily an experimental lacility tor the design, assembly and lesting of gas and/or liquid systems at pressures up to 120,000 psi. The 22.000 square foot building has twenty reintorced concrete test cells for use in proof, burst and leak testing of vessels and high pressure assemblies. In support of these activities, the lab has a machine shop, two high bay assembly areas, welding and brazing facilities, and a gas mixing/analysis laboratory. Several compressors and hydraulically operated pressure systems contain approximately 500 callons of hydraulic oil. A small acid etching and rinse tank operation is located in room 1220D. In addition, small quantities of solvents have been used at this laboratory for general cisaning purposes. 


\section{Apolicable Decuments:}

The following documents and references form the basis for this plan.

These documents are not necessanily all encompassing and reference to them is not to be constnued to mean that they are the only guidelines used to develop and implement this plan.

1. FSP 343, Facility Safety Procedure for Building 343, latest issue in effect.

2. LLNL Health and Safety Manual, latest issue in eflect.

3. "Hazardous Waste Handling Practices, Mechanical Engineering Deparment", notes by Brad Thomson, Dec. 1989.

4. "Guidelines for Waste Accumulation Areas", by J. M. Hirabzyashi, LLNL, March 1989.

5. "Guidelines for Discharges to the Sanitary-Sewer System", by C. H. Grandfield, LLNL, August 1989.

6. "Preparation Guide for Generdtors of Hazardous Chemicals and Radioactive Waste at LLNL", by J. Huss, LNL, March 1987. 


\section{Irainino and Awareness:}

It is the firm belief of the Building Menagement that an eflective program in waste minimization has to rely on the full cooperation of the employees and visitors to the building and that training and an awareness program of issues pertaining to waste manageme, $i$ has to be formulated, monitored and adherej to. As stated in the FSP 343 , attendance in vario', sclasses dealing win Environmental. Health and Safety policies is required for the building employees. In particular, EP.0006 "Hazardous Waste Handling Practices at LLNL" is renuired annually.

Each employee has at his disposal and relerrai copies of the reterences and documents listed above. In addition, the building management holds a one hour meeting twice a month with all the building employees to discuss new management issues, setety and health items as well as notewonthy comments related to waste generation and disposal procedures. The building has been segregated in such a manner that every employee is responsible for the housekeeping, maintenar. 9 and waste handling practices for a specific area, cells or storage space. Thus the individuals are not only responsible for being aware of proper procedures but they have to actually put them into effect. 


\section{Waste Generation Identicication:}

The High Pressure Laboratory, compared with other lacilities at LLNL, generates relatively little waste and very little hazardous waste.

Nevertheless this plan intends to clearty identity those areas and material types which have in the past been generated into waste, what materials are currently stored in the building, and plans te minimize future precuremem of mat arials which would subsequently be tumed into possible hazardous waste products.

1. Documentation of past waste disposal will be reviewed. Hazardous waste identification as to type, quantity and periodicity will be tabulated as a stanting point. An analysis will be made to determine il any up or downward trends in quantities can be associated with work load and type of activities ongoing at that time.

2. Further identification will be made of materials and waste which previously night . ot have been considerad to resuh in hazardous waste.

3. Past practices will be discussed with all employees and a plan will be formulated to have everyone provide a list of materials they consider sssential, usotul, and not necessary. An estimate will be made of the quantifies used and what inventory levels need to be maintained.

4. Current inventories of these materials will be collected and labuialed.

5. In addition, a review vill be made of quantities of waste not normally considered hazardous. This will be used in subsequent analysis and plans to minimize non-hazardous waste. 
Current Waste Minimization Practicas:

The following practitas have been initiated during the last twelve months in an eflort to reduce waste generation and the need for waste disposal:

1. The cooling liquid mixture of Trim Sol and water (which is used in all cuiting and machining operations in the machine shop areas) are treated by the MFD Division on a monthly casis to centrituge and separate any hydrocarbons and contaminants from the cooling solution. This extends the usofulness of this solution and eliminates having to dispose of it as hazardous waste.

2. A solvent cleaner/w:sher cabinet which used petroleum naphthas and other volatile solvents has been eliminated. A water based cleaning system has been adopted tor cleaning machined components.

3. The hydro test cells previiusly used a water solubie oil as the pressurizing media. This has been convened 10 a 50:50 water and antitreeze (ethylene glycol) solution. Furthermore, test anticles to be hydro iested are now pre-filled with distilled or tap water which allows the tested components to be drained into the sewer system. The quantity of polyglycol used in this system is being monitored.

4. One set of rinsing tanks and a solde fing station has been removed from the building. This eliminated the use of chromic and nitric acid. The one remaining station now uses two dip rinsing tanks for the small amount of nitric acid used in the cleaning operation. A log of these tanks is maintained and the concentrated rinse solutions are handled as hazardous waste when appropriate.

5. The hydraulic oil used in the isostatic bonders and compressors is now fittered and purified on a regular maintenance schedule. This will extent the time interval for oil changes in this erfuipment.

6. Several old compressors which showed wear and tear and small arnouris of leakage have been replaced with new, stale-of-the-an equipment which has substantially reduced the amount of clean up and soiled rag cisposas.

7. The building janitorial service has inslituted a project 10 collect and recycle all aluminum cans nomally disposed of as waste. 


\section{Euture Waste Minimization Practices}

Additional action items hove been identified to reduce the waste generated at th's facility. They are listed bolow. New items and procedures, which ma; be lorthcoming from noteworthy practices at other facilities or as they are identified by the employees at the High Pressure Lab, will be added to this plan.

1. Reduce the use of aerosol cans of fluids such as WD40, glass cleaner, spray paint, өtc.

2. Recycle tne ink cantridges for copy machines and printers.

3. Minimize the amount of hydraulic oil leakage and clean up by oliminating and/or replacing old compressors and pumps which require frequent overhauls and maintenance with more up to date and new equipment.

4. Make everyone aware of the need for reducing the use of solvents for cleaning, degreasing, eic. 
Irackino Reportine and Beview:

The original of this WMP343 will be kept with the Facility Engineer, room 1018A of building 343. This document will include the records of hazardous waste which was generated and disposed of during the last one to two year period. It will also include any documentation which has been genereted on inventory levels of solvents, oils, acids and nther hazardous inaterials. These documents will be reviewed and updated monthly. A summary repon will be prepared and sent to the N.E.E.D. Division Office, the HC Safety Team Leader and Hazardous Waste Management. 


\section{LER89-1012-01}

\section{Waste Minimization Plan Bldg. 141 Special Processing Facility Electronics Manufacturing Group}

Cal Sato and Ralph Hersey February 5, 1990 


\author{
LER89-1012-01 \\ WASTE MINIMIZATION PLAN \\ BLDG. 141 SPECIAL PROCESSING FACIITY \\ ELECTTONIC MANUFACTURING GROUP
}

Cal Sato and Ralph Hersey 


\section{SUMLVARY OF CURRENT AND PLANNED ACTIONS}

The Electronic Manufacturng Group is eliminating sources of hazardous waste gentatation in its Special Processing Facility in Building 141 by using alternative processing chenistries and technologies. Materials and chemicals such as cyanide, chromic acid, butox ethanol, mercury, lead, ar.d solvents wre listed as banned from land disposal (The Land Ban Act, 1984 amendments to the Resource Conservation Recovery Act RCRA), and are used in the process to manufacture printed wiring boards; chemic lly machined products and metal finishing Cyanide has been elipainated from metal firishing, and hazardow Solvents are being replaced by non-hazardous aqueousagents. The chromic arid etch system will be replaced with less toxic sulfuric acid etch system during the 2nd quarter of $F Y$ ' 90 . Specal Processing is searching for substitute processes, chemicals and materials to maxinize compliance with regulations.

Spacial frocessing and Material Fabrication Divisions, Electroplating and Metal Finishing Facility, joined efforts to evaluate, procure, and install a vacuum distillation system that will allow recovery and recycling of their process rines water. This acquisition should occur in FY' '90. More than 90\% of the waste discharged from these facilites is water. The vacuundistillationsystem will reduce the discharge volume by $90 \%$, which has a direct impact on disposal costs

Special Processing's upcoming, March 1990, installation of its new sulfuric-peroxide etcher will replace the existing chromic-sulfuric acid etcher, which will include recovery and recycling of copper sulfates. The re placement metal finishing line, pla. _ed for installation in May 1990, will replace the trichlorethane degreaser with a soap-roak deaner.

Alternative pronessing chemistries and technologies are being evaluated to minimize waste. In inid FY '89. a flasma etch system was installed for surface conditioning of plastic and other surfaces for subsequent metal coatings. This eliminated the need for several hazardous concentrated chermicals. The outlet vapors from the plasma etcher are passed through a flume scrubber thát neutralizes the vapors in a significantly less hazardous sodium bicarbonate solution. Altemative processing chemistries coupled with altemative rinsing techrologies an significantly reduce waste water generation. Special Processing is continuing its search for cost-effective methods to minimize the amount of waste discharged from the facility.

Other facility improvements are in process to reduce the danger of coptuminating the etrizonment with hazardous materials. Special Processing's sging and non-compling underground piping and sump system is being replaced with above ground complying systems. The teid waste stream plumbing and sump was replaced in Finge. Equipmentend installation plans to replace the Solvent and tromic waste stream system are in process and should be complete by May 1990. Improvements to our Waste Accumulation Area will be evaluated in January and February 1990. Facility' improvements will continue towards our goal to minjmize our hazardous waste discharge and to approach zero hazardous waste if at all possible. 


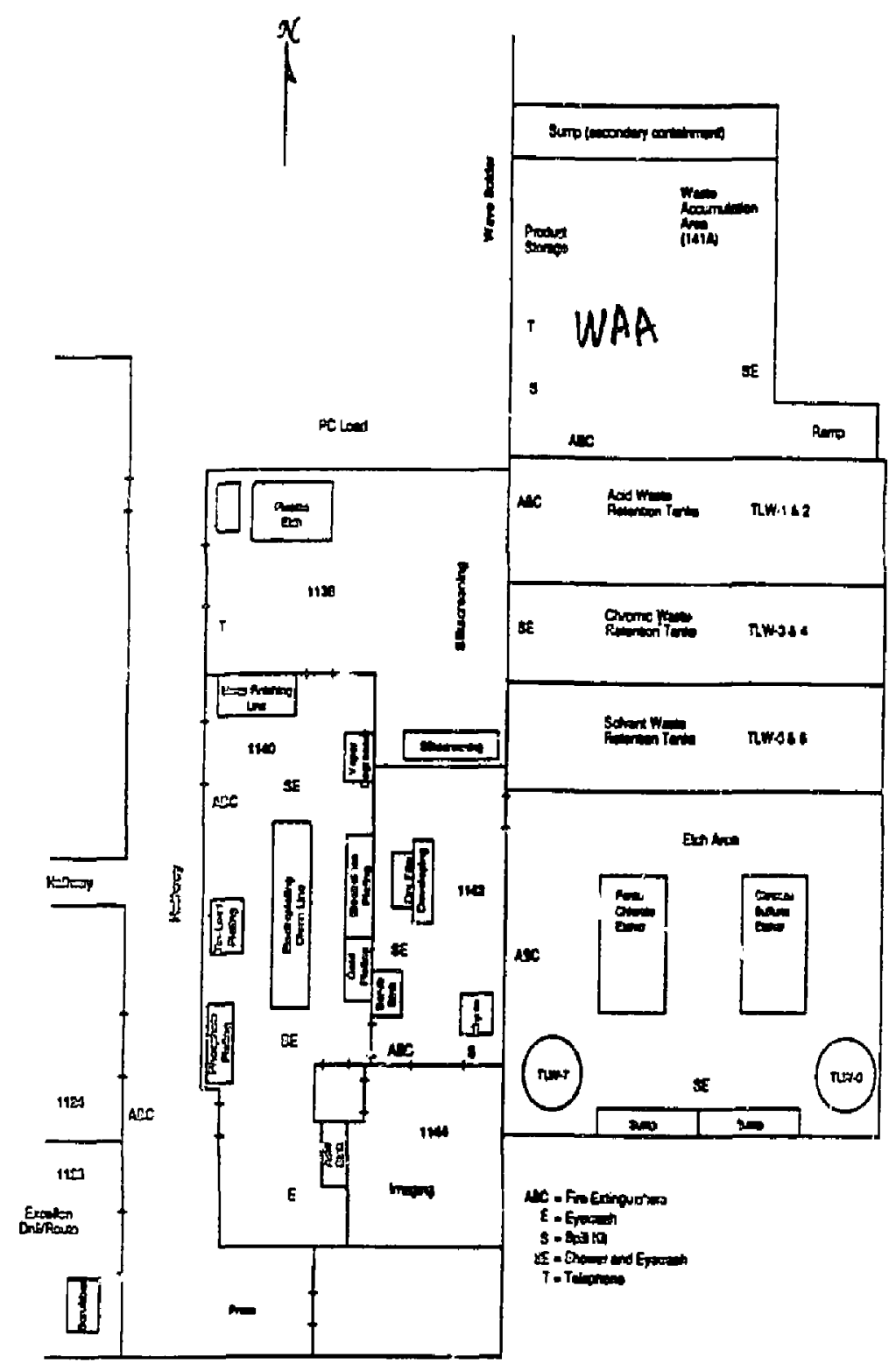

(SE Cotrax, B(t). 141)

Figure 1. Building 141 Specai Prwoessing Arra 


\section{INIRODUCTION}

\section{Purpose}

The Special Processing Facility, along with the rest of LLNL, has a responsibility to minimize the generation and discharge of hazardous waste. There are several federal and state regulations that control pollution through restrictions and inspections of our facilities. Special Processing will minimize their hazardous waste through: 1) source reduction and substitution; 2) recycling and recovery; and 3 ) waste treatment. This donment will provide faclity personnel and management a resource to identify, plan, take acion, and document waste control and minimization issues. The plan is titled "CLEEN", defined as Clean Livermore Engineering's Effluents Now.

\section{Facility Overview}

Special Processing is a facility within the Electronic Manufacturing Group of Electronic Engineering's Engineering Services Division. The facility is located in Building 141, Bay 1 (see Fig, 1). The facility provides corcurrent on-site service for experimentation, one-ofa-kind, and prototype product for all LLNL Programs. The processes of this facility that generate hazardous wastes are: pristed wiring board fabrication, chenieal milling, and metal fivishing.

\section{Background}

Thie Special Processing Fasility in Building $141 \mathrm{com}-$ menced operation on Jaruary 5, 1980. The facility was designed and constructed to meet the state and federal regulations imposed on a faciity of this type a! that time. All of the rinse waters and concentrated waste is captured in retention systems separate from the $L L N L$ Sanitary sewer systern. The rinse waters were separated into three waste streams, the acid, chromate and solvent streams. Each of the waste streams accumulate in separate underground sump systems and are then pumped into their respective primary, above ground, retention tank. During the early years of operation, each of the recairied waste types were analyzed and discharged to either the sewer system (when appropriate to do scl or to an approved hazardous waste dump through LLNL's Hazandous Waste Maragennent system. As of 1987 all of the waste generated by the Special Processing Facility is being analyzed and transferted to LLNL's Haziardous Waste Management system for disposal.

\section{New Hazardous Waste Control Regulations}

Environnental concerns have sirce nesulted in even more stringent hazardous waste control regulations that afiect the operation of the Special Processing faciity. Major issues indude limitations to underground piping, sumps, and tanks; limitations on the use of or elimination of certain hazardous toxic materials; dosures of many disposal sites; and (most recently) the Land Disposal Regulation of certain materials. The effect of the new regulations is not necessarily negative: new production methods necessitated by the regula. tions can often result in actual improvement in the quality of the products. The suppliess of materials, supplies, and equipment used to produce printed wising boands have developed many new processes and products to help clean the envirorment and simultareously improve the cquality of our printed wiring boards. The Special Processing Facility will continue to minimize waste with a long range goal of zero waste discharge. 

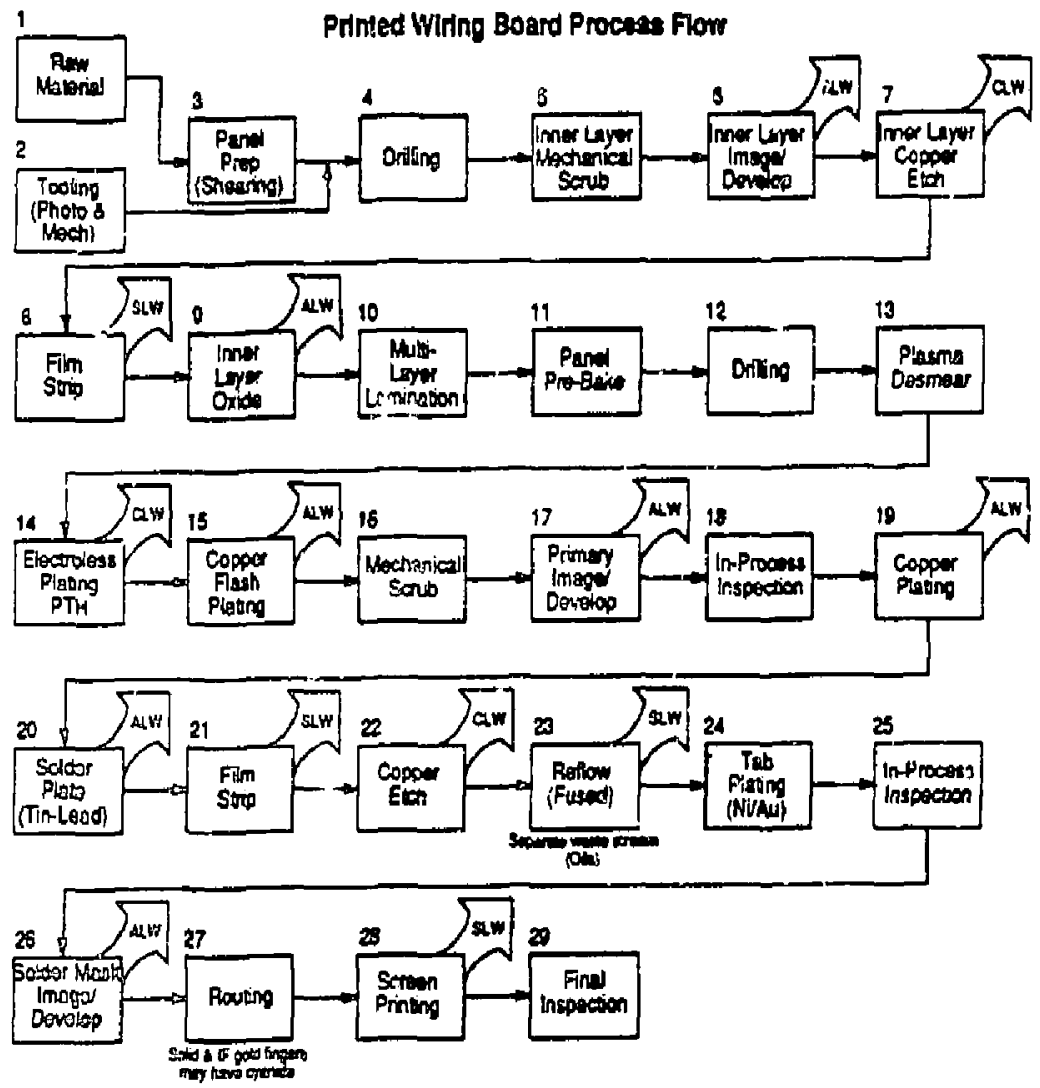

Metal Finlshing Process Flow
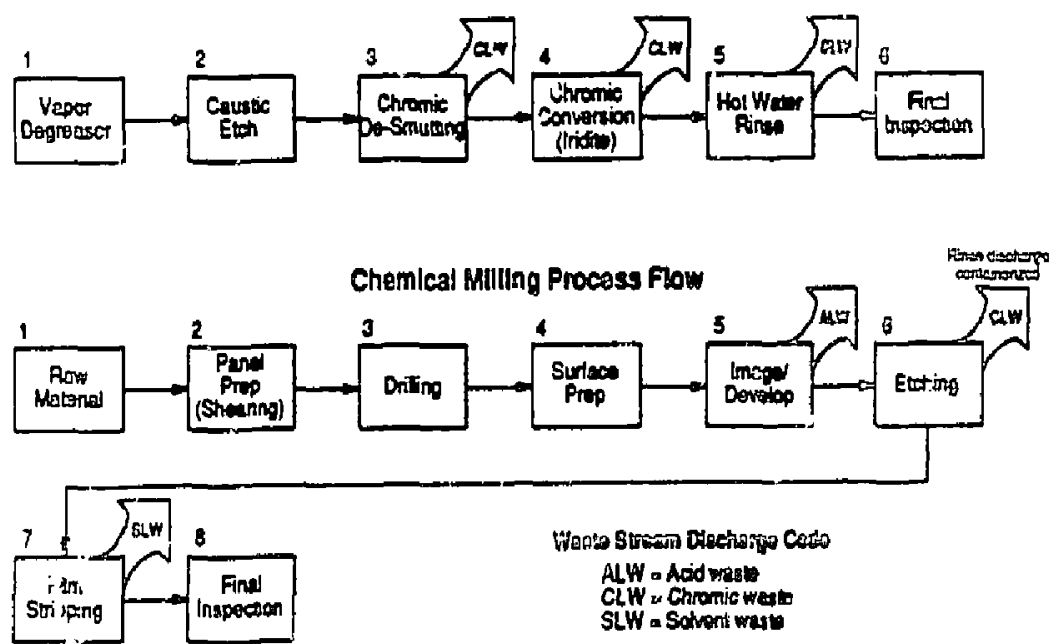

Figune 2. Building 141 Special Processing Area - Process Flow Diagrams 


\section{SPECIAL PROCESSING FACILITY PROCESS FLOW CHARTS}

There are three major processes in the Special Process ing Facility (see Fig. 2) that generase wastes. These processes are printed boards (primarily doublesided and multilayes plated-through hole printed boards), metal finishing and chemical milling.

The printed board process consists of about 20010300 individual process steps. These prress steps have been simplified in the Printed Wiring Board Process Flow chart in Fig. 2 to 29 process blocks. All the waste rinse water strears have been coded in the char as ALW for add/alkaline lab waste, ClW for chromic lab waste or SLW for solvent lab waste.
The metal finishing process is used to treat aluminium metal parts for electronic assemblies for corrosion resic tance and primarily to enharce the surface electrical properties of aluminum to ensure good electrical grounding.

The chemical milling is used to form two-d imensional metal parts thai connot be manufactured using tradjtional metal machining operations.

\section{CURRENT RUNSE CONFIGURATION}

Special Processing's scurrentrirseconfiguration is shown in Fig. 3

Acid Underground Plumbing and Sump Bypassed by Aboveground Pump/Sump System

- Allows HWM to evaluate acid underground sump leak

- Aboveground systern meets existing regulations whereas, the underground systems now in use do not meet current regulations for secondary ontairunent.

General Rirse Process Technology for the Special Processing Facility

In genera], with few exceptions, all rinsing processes are based on a two-stage stagnant rinse after each chemical processing step. When the stagrant rinse waters become contaminated to the process limis, the tank rinse waters are pumped into the appropriate waste stream to the waste retention system. Due to rinse-tank size restrictions and space limitations, most two stage stagnant rinse tanks serve two processing chemical solutions. The geveral processing steps areas follows:

- Submerse the part being treated in the processing solution.
- When completed, lift the part oul of the chemical processing solution and allow the solution on the part to complete solution runoff until the drip rate is very low.

- Submerse the part with vigorous agitation in the first stage rinse tank.

- When completed, lift the par out of the first rinse tank and allow the rinse water on the part to complete solution runoff until the drip rate is very low.

- Submerse the part with vigorous agitation in the second sage rinse tant.

- When completed, lift the pant out of the second rinse tank and allow the rinse water on the part to complete solution runoff until the drip rate is very low.

\section{Rinse Process Seqquence}

This process sequence is used many times in the Special Processing Facility, bul a few of the exceptions need some explanation.

The electroless copper process rinse waters are not allowed to be contaminated with other solutions, and 


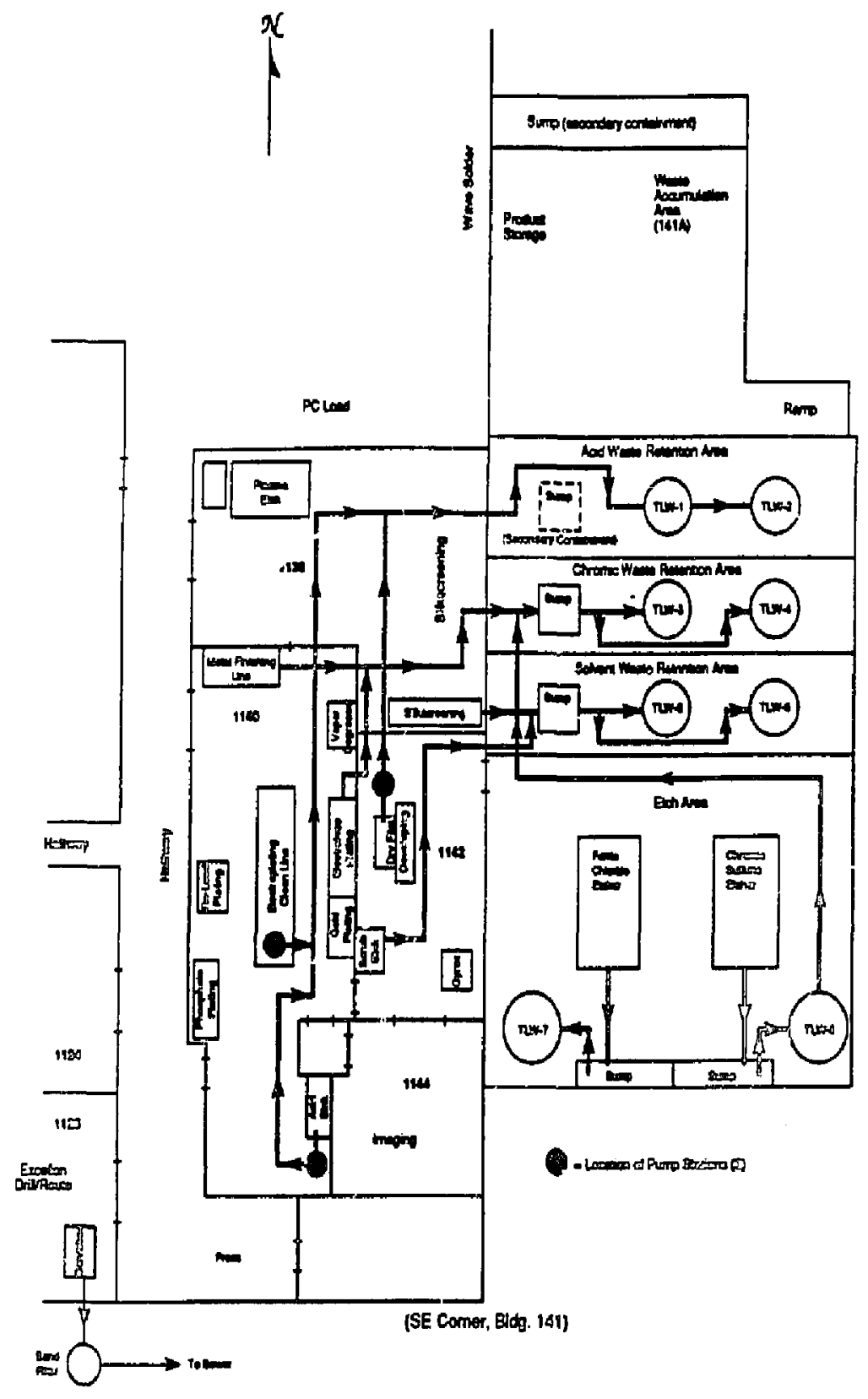

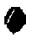

8

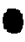

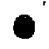

?

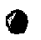

Figure 3. Building 141 Specisl Processing Area - Curent Rinse Configuration 
there is a threm-stage rinse tank as the last rinse in the elsctroless copper process line.

The rinse module on the chemioal machining etcher (ferric chloride) is a two-stage spray rinse. This inse madule is an inefficient rinse system and will be re placed by about April 1990 with the four-stage counter. flow rinse module currently on the printed board etches.

ine rinse module on the existing printed board etcher (chromic/sulfuric acid) is a vety eficient fourstage counter-flow rinse system with a recirculating spray rinse for each counter-flow stage. Oean rinse water enters the four-stage counter- How rinse at the exit (last) rinse tank and exits the rinse system at the first rinse tank The output waste water exits the first rinse tank and flow' to an aboveground sump from which it is pumped in to an aboveground storage tank Theflow of clean water is controlled into the last module by a conducovity controller. The basic operation is as follows:

- When the rinse water solution in one of the rinse module tanks becomes sufficiently contaninated, a conductivity controller turns the clean inlet water solenoid valve on

- Water flows at a controlled rate from the exit stage to the entrance stage (counter flow) until the conductivity controller senses the rinse water in the monitored tank has reduced in contamination to an established lower limit.

- When the convamination in the monitored rinse tankis below theestablished limit, theconductivity controller tums the clean inlet water solenoid valve off.

A multistage casonde rinse combined with vigorous agitation and conductivily controllert rinse water flow is a very efficient and effective rinse system. When the new printed board etcher is installed, this multistage rinse system will replace the existing, less-afficient single-pass spray etch module on the chemical machining etcher.
General Design and Operation of the Rirse Water Waste Retentlon Sytem for the Special Processing Facility

The Special Procassing Facility in Bldg. 141 was de $\therefore$ gned for adding the capability to recycle most of the rinse water used in the faclity. The capability to recl aim and recyeling ninse water was one of the major desizn requirements for the new Special Processing Facility. This was because the new faclity was designed in the late 1970s - the last year of a drought in Califorria. Water was being rationed and limited for both residential and indutrial use. At that time, the best available technology for processing rinse water for recycling in plating shop like operations was to sagregate waste water according to general content.

\section{Types of Rinse Waters}

The Special Processing Facility generated three types of general rinse waters.

One rinse water waste stream consisted of acid/alkaline waste water. The plan was to neutralize the rinse water by adjusting the $\mathrm{pH}$, precipitating out the salt, which would be removed from the water with a filter.

The solvent rinse water waste stream contained a small amount of solvents and other organic naterials, and purice and metallic copper from mechanical scrubbing operations. These materials could be removed from the rinse water by two stages of filtration, one particle fller to remove pumice and copper, and carbon filters to remove the solvents.

The third rinse water waste stream contained chromic acid, copper in solution, and chelates from the electroless copper plating line. The plan was to react the chromic acid to a morestablechemical state, thenadjust the $\mathrm{pH}$ to precipitate out the salts, which would be removed from the water with a filter. All the treated water would then be passed through a "polishing" operation to improve the quality of the recycled water to meet the rinse water quality requirements. All the salts, sludges, and other materials would be appropriately disposed of as a solid waste or sludge. The water recycling capability was not installed, except for the scrubber/rinse/dryer where the rinse water is recycled through a sand filter to remove metallic copper and abrasive materials from the rinse water. 


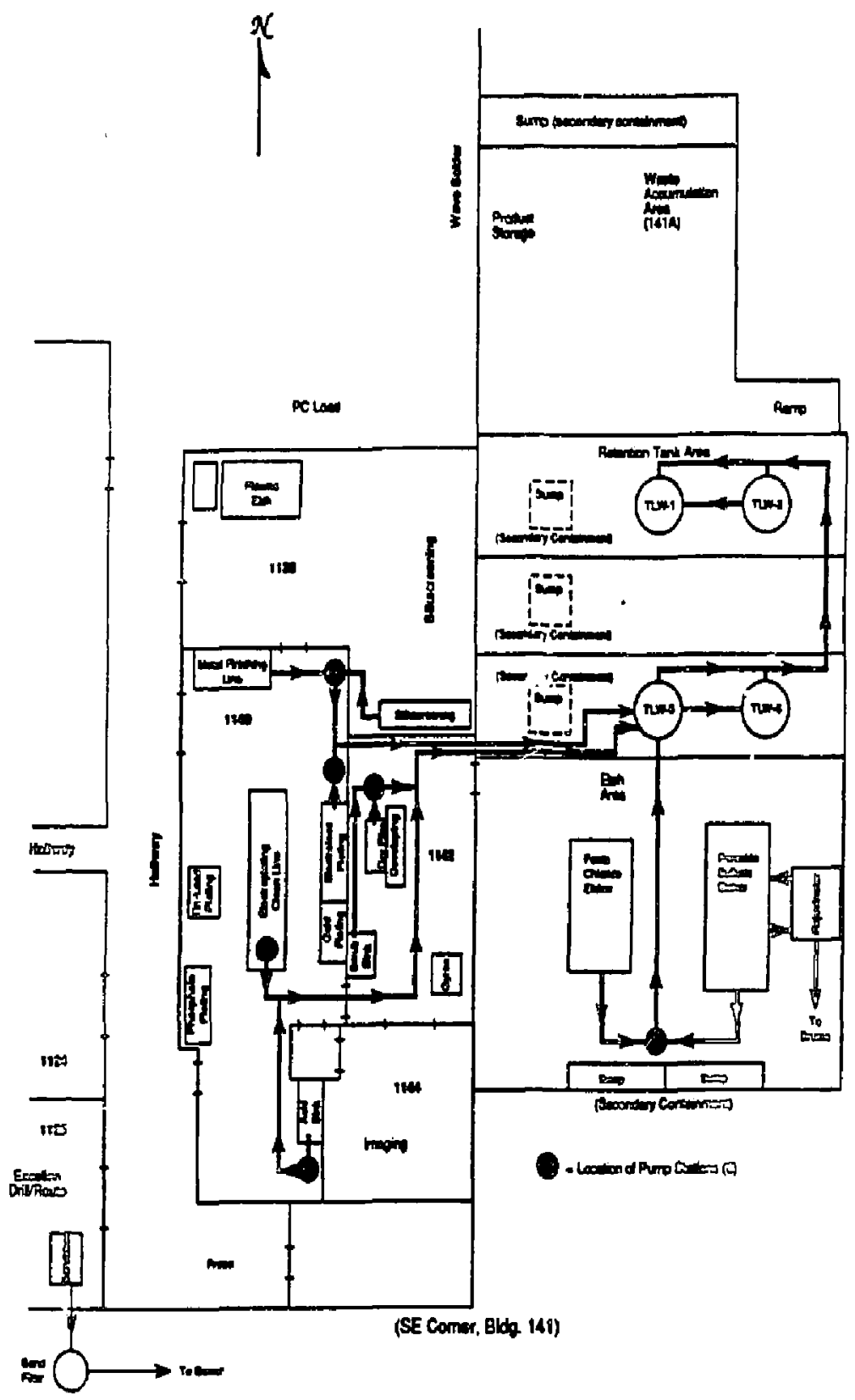

Q

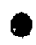

Figure 4. Building 141 Specil Processing Area - Planned Rinse Configuration with Abovezround Plumbing 
The rinse water waste streants hive separate sumps transfer purnps, controlsystems and slorage tanks. The planned operation of the wasteretention system was is allow the rinse water waste to accumula te to a predeter. mined level in the underground sumps. At a preset level a pump transfers the contents of the sumps to ore of a pair of above ground storage tanks. When one storage tank is filled, an alarm is sounder (which has to be mantually reset) to alert Special Irocessing Facility personol, and the transfer pump's output is switched by solenoid valves to the se.ond storage tank. When a storage tank was filled, Hazands Contol would atrange for waste disposal in one week.

\section{PLANNED RINSE CONFGUIATION (Above-Ground Plumbing)}

Specal Processing's rinse configuration requires certain upgrades to conform lo existing regulations. Mans to upgrade the risse configuration coincides appropriately with plans to minimize the volume and hazardous types of waste. The planned rinse config:ration is shown in Fig. 4.

\section{Ab andoning Underground Sumps and Plumbing} A major issue of nonconformance to regulations involves the continued use of the underground sump system, which is not secondarily contained, in the chromic and solvent rise discharge system. We will combine each of our waste rinsestreans (acid, chromic. and solvent) into one stream and concurrently abandon the use of the underground sump. Note: this is not mixing of chemicals as much as mixing different rinses that are basically comprised of water (98\%) with trace amounts of acid Aboveground sumps and plumbing will be installed, similar to the acid rinse discharge system previously installed. This new system will uptrade the balance of our wet-processes, which includes; the metal firishing line (chromic), screen-printing(solvent), dry-film developing (solvent), sonib sink, ropper etcher, and chemical milling etcher. The existing retention tanks, except the chromic tanks, will continue to be part of this rinse discharge system. The solvent retention tanks will be the primary tanks and the acid tanks secondary. The chromic tanks will be removed and the area prepared for a vacuum distillation system described below (see Fig. 4). This upgrade is part of the initial steps to minimize our waste volume through distillation. Each of the underground sumps will be us d as additional volume for the bermed area surrounding the retention tanks. We estimate compietion of this system to be in April 1990.

\section{Substituting Processes and Chemicals}

Concurent to abandonment of the underground sumps, we are actively substituting processes and themicis to reduce the hazardous materials used to mar.ufacture our products. The replacement chemicals are not included as "Land Ban" materials. These include:

- Metal finishing process: Complete tank replacement to include replacing the Trichlorethane Degresser with a sodium-hydroxide soak cleaner and replace the chromic acid panel cleaner (desmutting) with non-chromicdesmulting chemistry. The existing tanks iave temporary fixes for leaking seans. Estimated completion is June 1990. This finishing process continues to include chrome in the conversion coating. We are continuing our search for coatings that do not include chrome and meet product quality and performanze specifications.

- Copper etching process: Replace the contamirated, leaking and obsolete etcher. Replace the chromic-sulfuric etchant with hydrogen peroxidesulfuric etchant. Install an etchant rejuvenation system in-line with the etcher. Estimaizd completon is March 1990. The Environmental Protaction Department will assist us to determine whether or not a permit is required to operate this etcher rejuvenation system.

- Screen-printing process: Replace the hazardous cleaning solvents withenvironmentally safe cleaning agents. We are currently in the final stages of approval and replacement of our stock with an aqueous cleaner as the replacemeni. Estimated completion is February 1990. We are continuing 


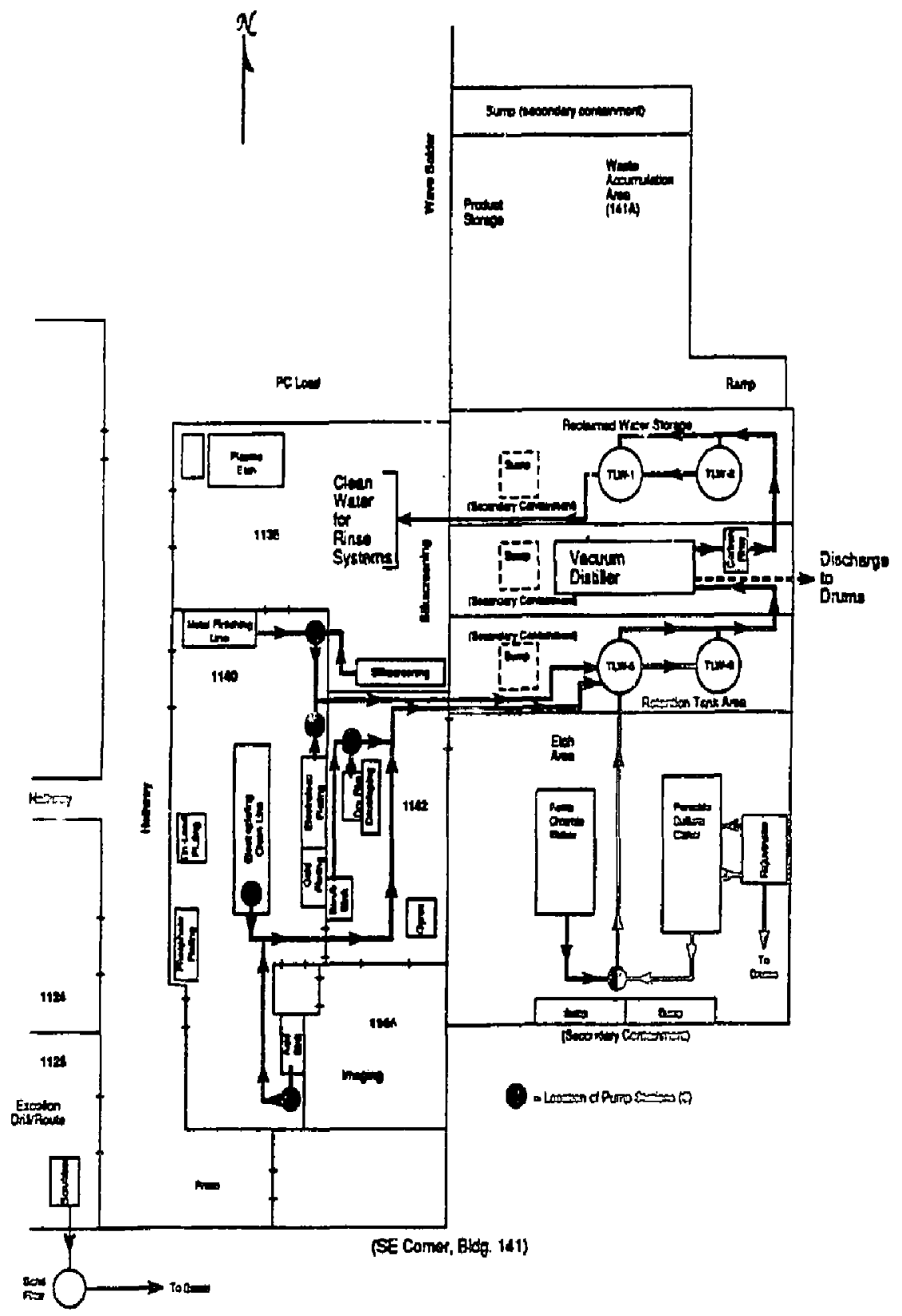

e

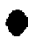

(

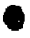

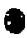

Figure 5. Building 141 Special Processing Are - Rinse Configuration

Vacuum Distillation Proposal 
our search for water based screen-printing inks that will meet product quality and performance specifications.

- Imaging process: Locate and convert from semiaqueous inaging film to fally aqueous film. This conversion will allow replacement of soivents used for the imaging process. We are aware of existing fully aqueous systems that will require evaluation. No estinate of completion date at this time.

\section{PLANNED RINSE CONEIGURATION (Vacuum Distillation P' Jposal)}

Special Processing's aboveground waste retention system will be modified, as shown in Fig. 5 , to mirunize nrse water discharges. Rinse water dircharges will be significar,ly reduced by vacum disillation of the rinse water dischange streans and recycling the distilled water. Further waste nirimization will be obtained by vacuum distillation of our concentrated ligvid waste prior to releasing it to HWM. The combined waste mirimization of both rinse water and concentrated waste will result in a total waste minimization of as much as $80 \%$ of our current liquid waste volumes. The estimated cosi for the vacuum distillation exquip. ment and installation is 5150,000 , and is planned to be installed in FY'90. The vacuum distillation unit may need envirsnonental permits in order to process our rinse water for recycling the rinse water within the Special Processing Fadilty.

\section{Modified Rinse WaterProcessing}

Current plans are to install the vacuum distillation equipment in the center section of what has been alled the Chromic Waste Retention Area. All rinse water waste streams will be collected in what is now the Solvent Waste Retention Area (Tanks TLW.5 and TLW. 6). The rinse water will be processed through the vacuum distillation urit. The vacuum distilled water will ice transferred to Reclaimed Water Storage tanks, which are now the tanks in the Add Waste Retention
Area (TLW-1 and TLW-2). The water in the ninse water storage tanks will be pumped into the Special Processing Facility for recycling the rise irater. The concentoted waste wom the vacuum distillation urit will be discharged into drums for suitable disposal by HWM. The vacuum distilled water from the vacuum distillation unit may need some secondary processing, or "polishing," in order to meet the rinse water quality requirements. The rinst water retention tanks (TLW-5 and $T(W-6)$ and the Reclaimed Water Storage tanks "ill need to be cleaned up and/or replaced. Depending on the condition of tanks ILW.1,-2,-5 and -6, they may need to be replaced due to mecharieal/chemical deterioration or saismic considerations.

\section{Vacuum Distllation of Rinse Water}

Vacuum distillation of our rinse water wastes can reduce our rinse water discharges by about $90 \%$. The reclaimed rinse water from the vacuum distiliation unit will be recycled through the Special Proressing Facility 35 new rinse waler. These are two benefits to recycling the rinse waters: First, by increasing the flew of water in our current rinse tanks, we will improve our product quality. Second, by recycling our rinse waters, we will reduce our consumption of high-quality water from LLNL sources by a proportional anouni. Tables 1 and 2 show our approximate current rinse water discharge volumes and the anticipated waste discharge volumes:

Table 1. Waste Discharge

Waste Discharge Straim

Gromic Write Stream

Soivent Waste Stream

Acid Wasle Strearn

Total Waste Discharge

$\begin{array}{cc}\text { Waste Discharge Volume (gallyr) } \\ \text { Current } & \text { Future } \\ 9,000 & 900 \\ 15,000 & 1,500 \\ 17,000 & 1,700 \\ 41,000 & 4,100\end{array}$




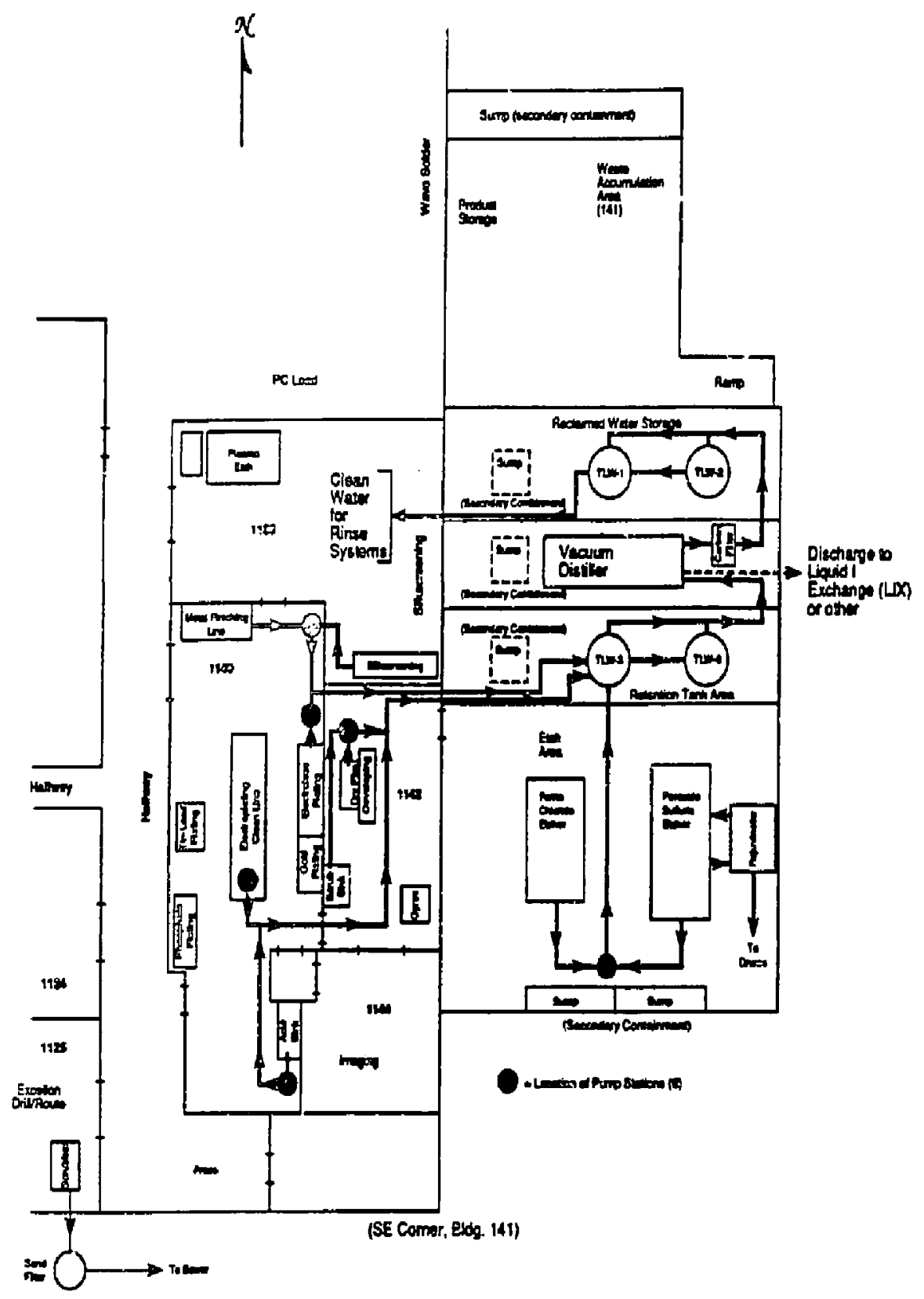

0

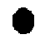

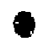

9

-

Figure 6. Building 141 Special Processing Area - Future Rinse Configuration 
Vacuum Distillation of Coacentrated Waste.

Vacrum distillation is plained to reduce the volume of concentrated lab waste from the Special Processing Facilities process chemical tariks and equipment. Concentrated lab waste an be processed through the

Table 2 Concentrated Waste Discharge

Waste Dischage

Concentrated Lab Waste
Waste Discharge Volume (gal/yx)

Current Future

$4,800 \quad 2,500$

\section{FUTURE WASTE RINSE CONFIGURATION}

Additional post-processing for the Special Processing Facility is being considered, as shown in Fig. 5 , to achieve a "Zero Discharge" liquid waste gral. Current pians include the installation of vacurum distillation and some other post processing equipment to recycle most of the ri zse water within the Special Processing
Facility. Further waste reductions of water may be obtained by using liquid ion exchange (LXX) pos!-proceising of the vacuum distillation concentrated waste discharge stream. lon exclange columns will remove metals, chlorides, sulfates, and other chemicals from the waste in a more concentrated form.

\section{CONSIDERATIONS FOR APPROACHING MASS BALANCE}

One of our goals is to develop a mass balance analysis for the Special Processing Facility. Simply stated, mass balance for the Special Pronessing Facility is the ratio of the mass of all the matenal that enter the facility to the mass of the output products that leave the facility.

\section{Ideal Mar.s Balance}

There are two ideal mass balances: The first case is when all of the input produets are consumed in proc- essing or manufacture of the output product with no waste or recycled materials. The other ideal mass balance is when all of the input materials are consumed as final product or recyclable materials, in other words there is no waste (or scrap). In general, there ape few processes that do not generate some form of a waste product. The mass balance for the Special Processing Facility can be a simple flow diagram as shown in Fig. 7.

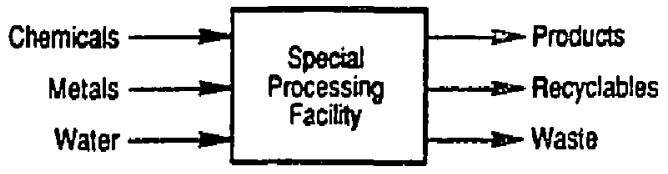

Figure 7. Ceneralized mass flow diagram for the Special Processing Facility 


\section{An Andytial Tool}

Mass halance is a new analytiol tool being applied to the Special Processing Facility. Initial efforts identified the riedd to accumulate the necessary data to perform a mass balance aralysis. The first mass balance analysis was based on the relationship of the square fookge of metal-clad base material laminate purchased and the volume of waste rinse water ard concentrated liquid wastes for the year 1989 . The rass balanoe for 1989 was determined to be $143 \mathrm{ga} / \mathrm{sq}$.t. : We will continue to use this ratio until better relationships are ätreloped.

\section{$\frac{45,800 \mathrm{gal} \text { (Concentrated and rinso wator wate) }}{3,400 \mathrm{sq} \mathrm{h} \text { (Coppor laminate) }}=14.3 \mathrm{gal} / \mathrm{sq} \mathrm{h}$}

This mass balaree ratio is not a accurate number be"zuse the square lootage of metal-clad base material lamirate is not anaccurate representation of the amount of lamia te processed in the facility. Until recently, the Special Processing Fadity did not maintain an invencory or use record of laminate materials. We have now instituted a $\log$ to record the use of laminate materials. Therefore, with time, we will be able to obtain mure accurate mass balance numbers. As planned, swe will be deteminin; which data will be needed to provide a more mearingtul mass balance ration in the future.

\section{Mass Balance Example}

Mass balance can be applied to individuai processing operations. As an example, we will analyze the copper electroplating uperation that consists of a heated copper pyrophosphale plating tank followed by a rinsing operation. The heated coppes plating tank requires the daily addition of water and ammonium hydroxide to make-up for evaporation losses. Currently, the rinse tarks following copper plating are also used for rinsing other materials and the rinse water effuent is accumulated in the waste rinse water retention system The current copper plating and rinsing process low char is shown in Figure 8. Let us focus on the utilization of water. Note that water enters the plating tank to compensate for evaporation loss, and that water enters the rinse tank and leaves as an effluent (to the waste rinse water reiention system.

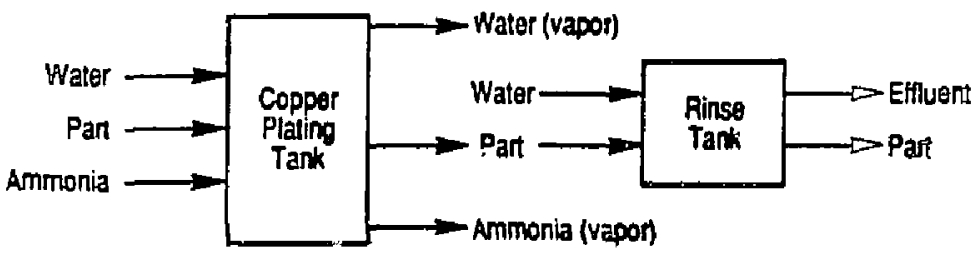

Figure 8. Current copper plating and rinse process flow chart

\section{Modifying the Copper Plating Process}

Consideration is being given to modifying the copper plating process by adding a multistage counter-flow rinse system after the copper plating operation. We plan to use the effuent from the counter-flow rise system as the water source to make-up for evaporation losses from the copper plating tank. This actomplishes two key grals: First, it keeps the ammonia out of the rinse water effluent collected in the waste ninse water retention system. Second, copper and other constituents of the copper plating bath are recycled back into the plating tank and out of the waste rinse water retention system. Thismodified copper plating process flow chart is shown in Figure 9. Note that this is almost a zero-discharge, mass balanced process except for the water evaporation and anmonia vapor losses. 


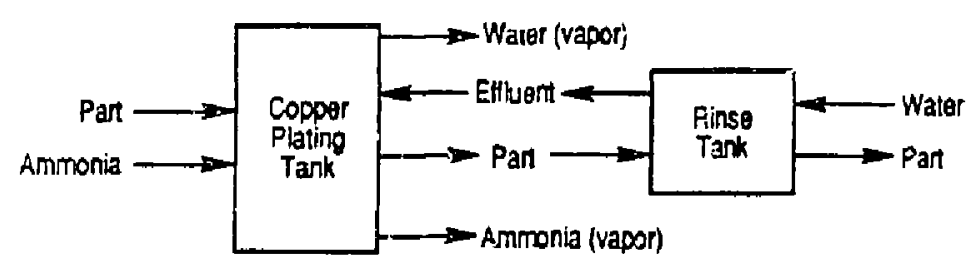

Figure 9. Modified copper plating process using recycled tinse water rffuent

\section{Additjonal Studies}

We will conduct additional studies to achieve zerodischarge and mass balance processing on both a process and system level scale. 


\title{
MATERIALS FABRICATION DIVISION \\ WASTE MINIMIZATION PLAN
}

\author{
J. W. Dini
}

February 14, 1990

\section{Introduction}

The Materials Fabrication Division (MFD) is a specialized division within the Mechanical Engineering Department. It supports LiNI. by providing many of the components needed for the Laboratory's diverse programs.

Because of the research and development nature of LLIVL, MFD often is called upon to develop new equipment and methods. It must maintain a repertoire of capabilities which inakes almost any manufacturing job possinle. This requires sustaining a high level of technological expertise as well as a comprehensive inventory of upto-date machinery. Almost 400 people and approximately $\$ 20$ million worth of equipment als channeled into this effort.

MFD fabricates parts from a variety of materials, instuding ferrous and nonferrous metals, plastics and ceramics. The division also works with materials associated with nuclear technology, such as beryllium and uranium, as well as high explosives. MFD is equjipped to produce parts which range in size from miniature, such as ons millimeter diameter laser targets, to very large, such as five-foot diameter canisters. Fabrication and inspection requirements in the one ten thousandth-inch region are commonplace, with many components specified in the low microinch domain.

The main fabrication complex occupies about $\{50,000$ square feet. In addition, 23 area shops are located throughout the Laboratory. Site 300, where high explosive devices are machined and assembled and used in test, is located about 15 miles from .ivermore.

MFD is committei to an active rogram on waste minimization (see Appendix A) and the purpose of this document is to outline the plan of action. 


\section{Waste Minimization Assessments and Strategies}

Waste minimization assessments within MFD will include four major steps: 1) information gathering; 2) identification and screening of potential waste minimization options; 3) evaluation of technical and economic aspects of potential options, arid 4) implementation. Within MFD, the waste minimization assessment process will be an on-going program and not a one-time effort. Reviews will be conducted every six months, emphasizing the application of new technologies for waste reduction and recycling over treatment or disposal of wastes as illustrated by the example shown in Figure 1.

\section{Information Gathering}

\section{A. Identification of Waste Streams}

We are presently gathering information ideraitying the waste streams which are generated. These consist of waste associated with machining operations (e.g., machining conlants, ct.ips, solvents, rags, etc.), waste associated with plastics ope ations (e.g., plastics resins, catalysts and solvents), and wastes associated with plating operations (solutions containing dissolved metals, acids, bases, etc.). A preliminary waste minimization plan has already been developed for plating wastes since they are a large part of the wastes generated and this plan is included as Appendix $B$.

Figure 2 lists the waste minimization functional responsibilities and identifies key personnel from each area in which waste is gerierated. Areas not included are Site 300 and MFD area shops. A separate waste minimization plan has been developed for Site 300 ("LLNL Site 300 Facility Waste Minimization Plan", by M. A, Gonzalez and R. A. Heckman, Feb. 1990). Area shops are not formally covered in this plan since we rely on the respective program supporting the individual shop to do this. However, we will keep the shop personnel in these areas up-to-date on waste minimization education via training and technology transfer.

\section{Goals}

Our principle goal is to obtain a significant reduction of waste; quantitatively we would like to reduce waste by $75 \%$ within the next two years (by Jan 1992). loeally, we want to drive toward zero 


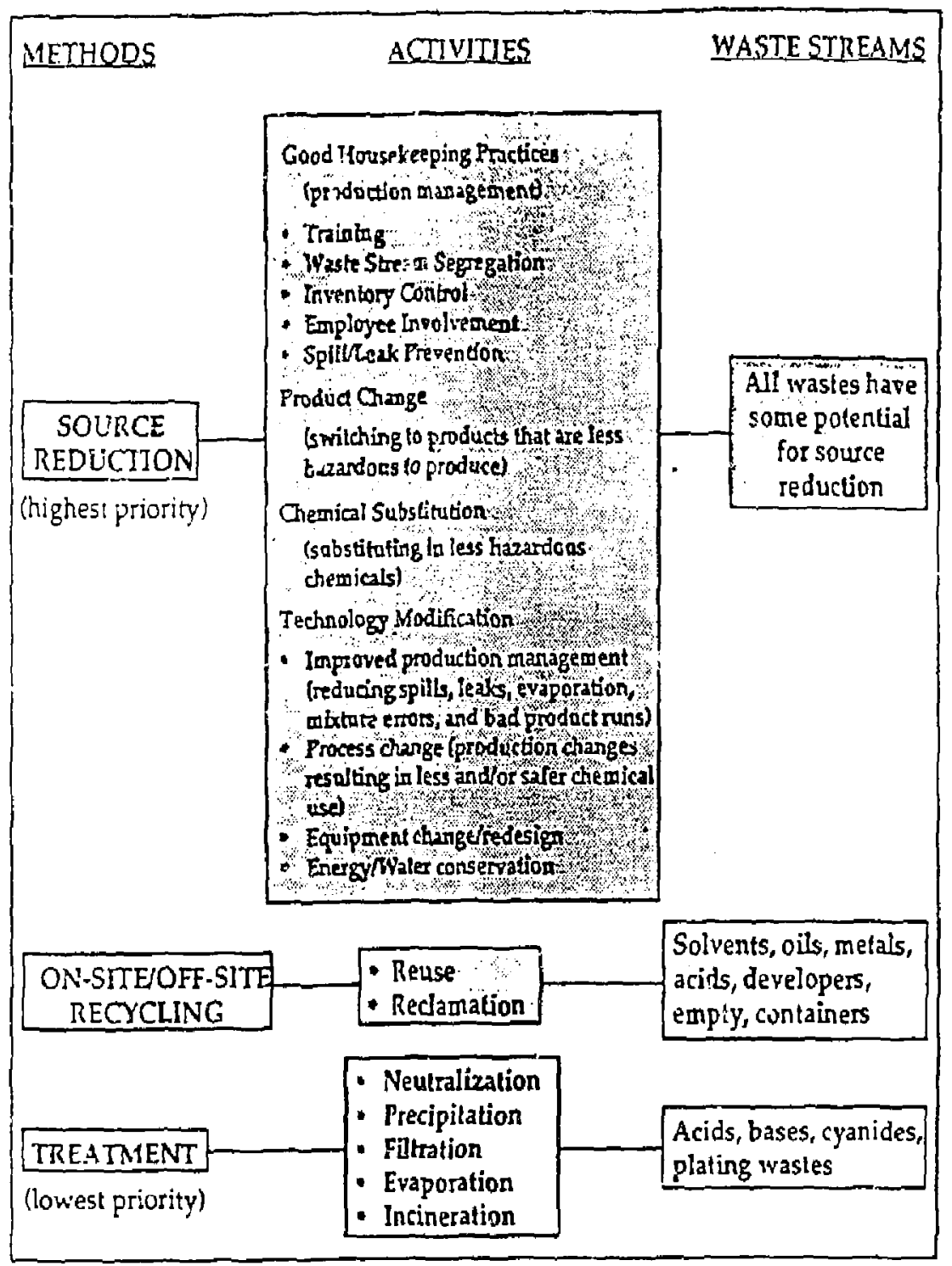

Figure 1

Waste Minimization Strategy 
discharge, but this will not be possible with some operations such as machining of toxic anji/or radioactive materials. Both source reduction options and recycling options will be included in the Jgram. Source reductions include such items as good operating practices, technology changes, material changes or product changes. Recycling techniques include use/rouse techniques and resource recovery lechniques.

\section{Status arid Acromplishments}

A waste minimization program team has been established. (see Figure 2) and will continue working the issues discussed in this repart.

A number of waste minimization issues have aiready been addressed and these involve items that are the heaviest waste generators in the division

An eveporation unit has been ordered for the metal finishing operation and this will reduce waste that has to be hauled offsite by $80-90 \%$ (for more detaiis, see Appendix B).

- We are now recycling machine tool coolant in the Main Bay nachining facility in 321 , and this is resulting in a reduction of $85 \%$ of material that has to be either treated on-site or hauled off-ste. Specifically, between January and July 1988, we sent 33 each, 55 gaitlon drums of coolant waste to Hazardous Waste Management. During the same period in 1989, when we were recyctiag, we sent 5 each, 55 gallon drums (see Appe, dix $C$ for details).

- A similar unit has beer ordered for our NC Machining area, also in the 321 complex. We anticipate this unit being on-line and operational by April 1990. We average 100 each, 55 gallon drums of coolant sent to Hazardous Waste Management from this facility per year. With the recycling unit in place, we expect approximately the same reduction that we experienced in the Main Bay (approximately $85 \%$ ), which means we will generate only 15 each, 55 gallon diums per year. 
FIGIVE 2

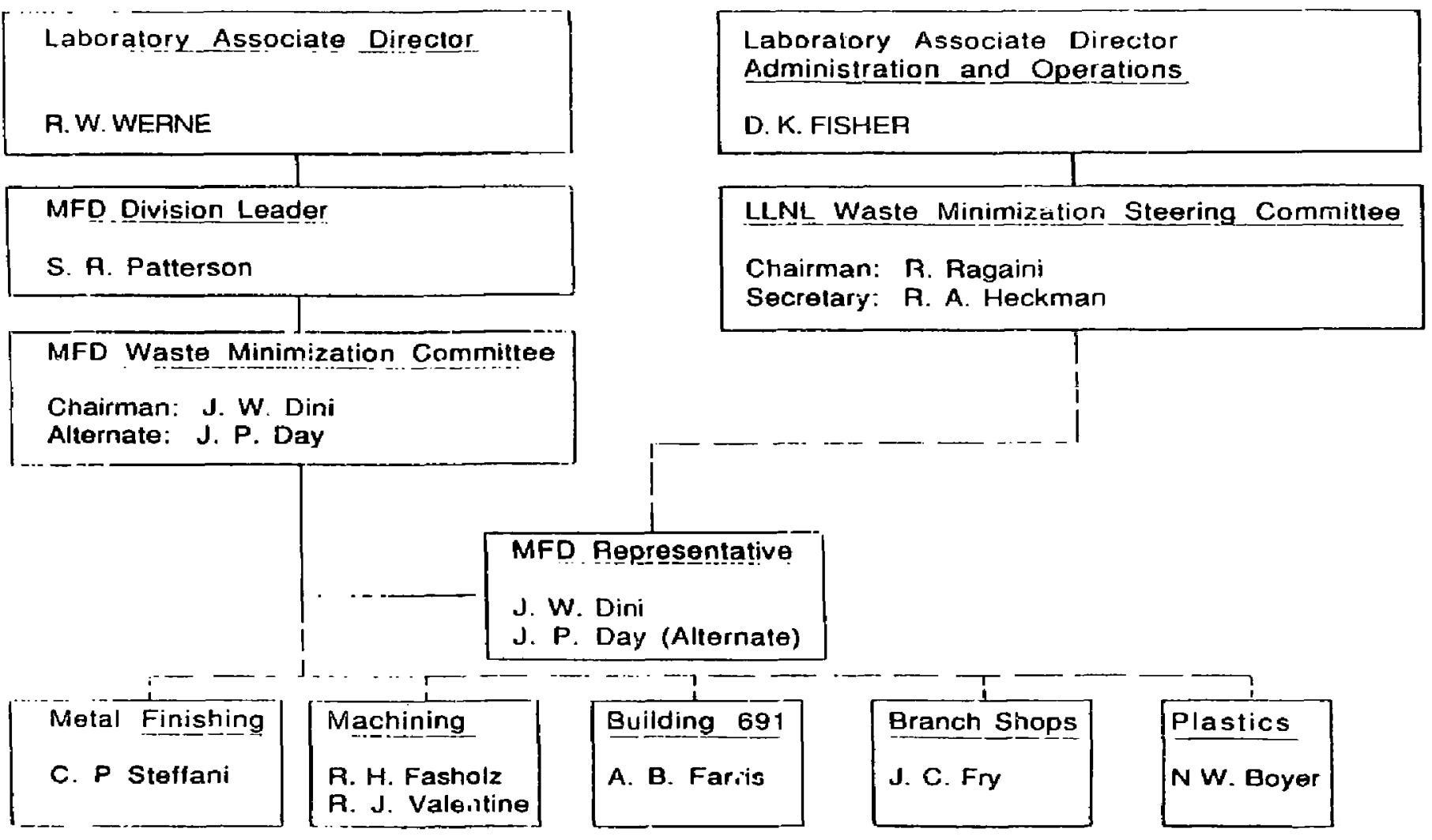




\section{Objectives supporting Environment, Safety AND HEALTH}

InCORPORATE AN INOIVIDUALS PERFORMANCE IN MEETING SS\&H GUIDELINES INTO HIS/HER PERFORMANCE EVALUATION

- Establish a ouantitative guide to all of MFo's waste STP.EAMS

- Develop a specific and quantittative plan for waste MINIMIZATION

- DEVELOP a fORMAL ES\&H INOUSTRIAL MATERIALS HANOLING PLAN

- ESTABLISH a PLAM THAT WILL ASSURE THAT ALL EMPLOYEes are KNOWLEDGEABLE IN THE ES\&H AREAS PERTINENT TO THEIR JOBS THROUGH TRAINING (FORMAL AND OJT), TESTING AND PERFORMANCE MEASUREMENT. THE PLAN WILL PROVIDE A MEASURE OF TRAINING EFFECTIVENESS.

REACH ZERO WALK THROUGH ERRORS IN ES\&H AREAS, INCLUOING HOUSEKEEPING

This is from a taik titled "MFn Division Briefina" aiven by Steve Patterson, Division Leader MFD, on January 31,1900 to MFD employees. 


\section{Introduction}

The plating Shop Yuilding $327 \%$, which is part of the Materials fabriczicon-firisjon, provines a viable, one-of-a-kind, on-site serviceto all Litr. programs. The facility provides processes such as electroplating, electroless plating, anodizing, cleaning, etching, electroforming and chemical miling. The only other facifty at HLll that provides electroplating ard sopface finishing services is the Felectronic Engineering EsD Printed circuit Facility (Builing (4)). This operation concentrates on plating operations required in the fabrication of printcd circuit boards; therefore, does not provide the extansive range of metal finishing processes that are available in the Building 322 plating Shop.

The MFD Plating Shop is important to all LLNL programs for two reasons: 1) it offers quick turnaround on many processes, and 2) it offers highly soecialized technology ihat is difficult and sometimes impossible to find elsewhere.

We in MFD are compitted to an active program on waste minimization, and the pu'pose of this document is to outline the plan of action.

\section{Overview of Minimization Plan}

In this section, we will review the plan including accomplishments, the current sitilation. short range goals, intermediate goals and long range goals. The olan is detailed in Table 1.

\section{Accompl ishments}

Elimination of chromic acid plating tanks - Two chromic acid plating tanks (about 300 gallons eash) have been used for LLin programatic work. The largest part of our chromic aci.' waste stream was generated because of these two tanks (another minor contributor is a dichromate treating solution for al uminum). As part of our minimization progran, the two chromium plating tanks werz decomonissioned in January 1989 and this service is no longer provided in nur shop. Customers with requirements for chromium plating are now referred to shops in the Bay area.

\section{Current Situation}

In our present oneration, we can identify one major waste strean art one

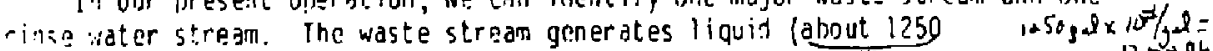
ga'? uns/week) which is transported off-site for treatment. The rinse water stroan generates anoroximately 10,000 gallons of water per day and this is manitarefl for bit and total dissolvad solids and, if athin proper limits, is discila:ned to the sanitary sewer. If nutside proper linits, it is transferreri ite 5 it a for disposal. 


\section{Short Range Goals}

Our short range minimiztion goals are threefold:

1. Reduce our major aste sirean by $90^{\circ}$,

2. Mininize discharge of rinse water to sewer system, and

3. Eliminate vapor degreasing in the shoo.

Quduction of thi major waste stream by $90 \%$ :

Our minimization plan inciudes purchase of a freeze vaporization unit which will allow us to reclaim and recycle water from this waste thereby reducing the volume of material which will have to be hauled off-site. The cost of the distillation unit is 578,000 and the order has been placed. We've been toid by personnel in EPD that we will have to obtain a variance to operate this unit. Our olan is to have the unit operational before June 1930 .

Hinimize discharge of rinse water to the sewer system:

4tthough we've had no problem with the issue of monitoring and then discharging our rinse water to the sanitary seiver system, our god is to recycle this water and minimize discharge to the sewer system. The distillation system discussed above wiil be used to recycle this rinse water and this coupled with procedural changes in shop operations should allow us to noticeably minimize discharge to the sanitary sewer system.

Elimination of vapor degreasing:

Our vapor degreaser utilizes about 700 gailons (ef perchlardethylene per year and also creates waste solvent that has to be disposef of in some manner. We plan on el iminating this operation from the shop and replacing it with a water pressure cleaning system. This new system recycles the water su waste is kept to a minimum. The cost of the new unit including installation will be about $\$ 15,000$. The unit has heen purchased.

\section{Intermediate Goals}

The intermediate goa!s consist of characterizing titu waste streams and evaluating recovery processes. To no this, we first nead to ijue the distillation unit aperationn' and time to neteraine it.s efectiveness. If it aroves to he as effective as we anticipate, we will perhaps ourchase a second uni:. Rogardless, tho stradms that we can identify includa: aickel, copper, rinses, zcids, alkalies, secrepopolish and miscellaneous. nut gat is to

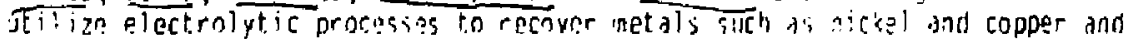


processes such as ion exchange for some of the other streams. He intend to evaluate the full gamut of recycling processes available for these streams. We anticipate completing this phase of the minimization program by January :99?.

Long Range Goal

The long range goal is zero discharge or sirce this coulr prove extrenely difficult, development of processes that will allow us to projuce a siudge cake that could be hardled by our Hazardous Waste Management Group. 
Table

Haste Hinimization Plan - Building 322 plating Shop

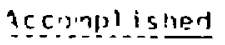

: iningtion of

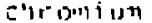

oluting tine

January 1999
Current. Situation

Waste generated

(1? 200 gallons/week)

Rinse water to seiver

(40,000 gallons/week)

Iccenther 1989
Short Range Goals

Haste generated

(125 ga) lons/weok)

Minimize rinse water

to sower (recycle)

Elillinate vapor degreaser

June 1990

\section{Intermedicte roals}

Characterize individual

waste streams and

evaluate recovery

processes: nickel

copper

rinses

acids

alkalies

misc

electropolish

Jonvary 1993
Long Range Goals

Lero discharge

or sludge cake

Hazardous Waste

Management Group

January 1995 


\section{Waste Minimization Organization}

The Waste Minimization Policy Statement of March 8, 1989 (Attachment 1), issued by the LLNL Laboratory Director, reflects the strong commitment by top management to implement waste minimization efforts at $L I N L$. To reinforce the need for inclusion of th. Director's policy in daily operations. Nuclear Design Program management has also developed a more specific policy statement applicable to waste minimization at Site 300 (Attachment 2).

As illustrated in Figure 1, several LLNL organizations have roles and responsibilities in carrying out the Site 300 Waste Minimization Program. The Nuclear Design Program Deputy Associate -inector (DAD) for Assurances has the responsibility for management of Site 300 safety and environmental programs. as delegated by the Associate Director for Nuclear Design (ND). The Site 300 Resident Manager has the responsibility for daily oversight of Site 300 salety and environmental programs. Knowledge of environmental compliance and operational safety requirements and implementation of these requirements is the responsibility of the programs and support organizations operating each facility or complex. Work is performed at these facilities in accordance with established Operational Safety Procedures and in compliance with environmental regulations. The DAD/ND, Site 300 Resident Manager, and program and operational suppor managers receive guidance and assistance in implementation from safety and environmental specialists assigned to Site 300 .

With respect to waste minimization, the DAD/ND provides the system for reviewing and auditing programmatic and support activities 10 ensure that waste minimization goals are being addressed. "the Site 300 Resident Manager provides the oversight to ensure that routine operations receive the proper review to ensure that both LLNL and Site 300 waste minimization policies are being incorporated into activities. The Nuclear Design Waste Minimization Coordinator coordinates assessment and implementation activities of all Nuslear Design operations and ensures that Site 300 waste minimization information is communicated between Site 300 personnel and LLNLDOE Waste Minimization Program personnel. 


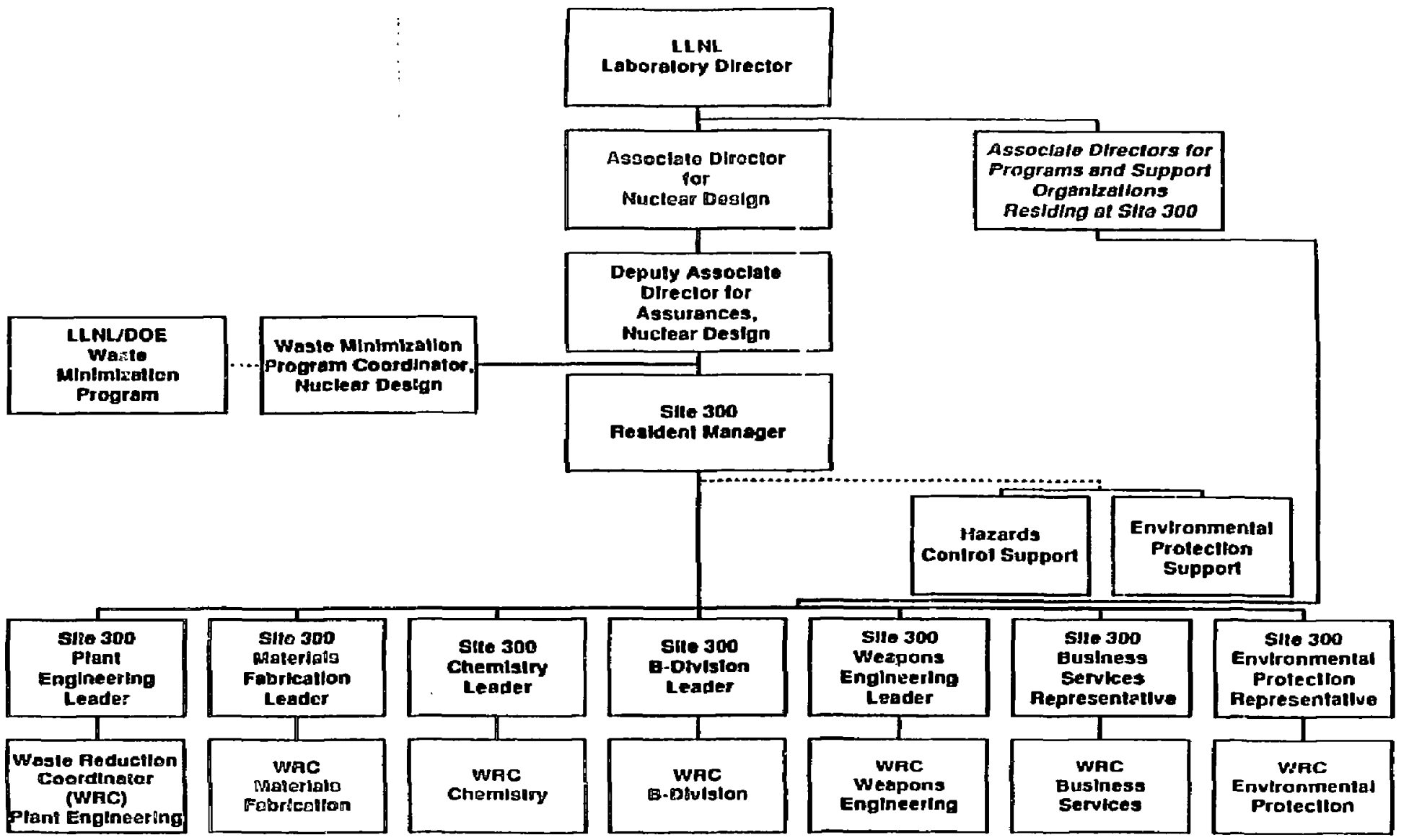

Figure 1. Functlonal Organizatlon Chart - Slte 300 Waste Minímlzation Program Solld lines denole lines of responslbility. Broken lines denole supporl organizations. 
This paper is presented by Dick Fasholz, a Senior Superyisor of the Main Bay Machining Facility wishin Materials Fabrication Division at Lawrence Livermore National Laboratory. The topic of this discussion is one aspect of waste minimization: the recycling of machine tool coolant within the 321 complex of Materials Fabrication Division. This peper will chronicle sone of the events which moved us into the recycling business, sumarize in detail the equipment and proceduces we use when recycing, and discuss our future recycling objectives.

The motivation for our entry into a tecycling effort stems fron the need to comply with the laws, ordinances, codes, restrictions and procedures of a number of government agencies, and also to minimize the resources associated with the handling and disposal of spent machine tool coolant which is classified as a hazardous organic waste.

In May of 1982, a memo from Calvin Ozaki, of the Lab's Toxic Waste Control Group, to Don Brazil, a superintendent in Materials rabrication Division, defined the procedures to be used when handling liquid wastes out of the 321 complex. This put us on notice that the re would now be considerable costs and effort connected with handing of liquid waste. This would be a combined effort among MFO personnel, hazards Control and Toxic haste control Group.

1 the next few years we operated according to the 1982 guidelines. During this time coolant and disposal studies were performed by George sutton of MFD which culminated in a 1987 funding proposal for two coolant recycling systems and $a$ builjing to house liquid waste handling equipment.

While this proposal worked its way through the system, we contacted people at Lawrence Berkeley Lab who had purchased a XYBEX coolant recycling system, and they invited us to see the operation. Two visits to Berkeley were made, The first, in early 1987, produced an agreenent whereby Berkeley would process our uncontaminated spent coolant through their system. Subsequently, we had to obtain a variance from the California Department of Health Services in order to transfer druas of coolant from Livermore to Berkeley and also allou Berkeley to perform the processing. In August, 1987. I became personnally involved in our coolant recycling efforts. I visited Berkeley to get a first hand look at theis operation. Larcy Calais, the Berkeley suspervisor of the opuration spoke highly of it. At this time, we also went over some fine points of the coolant transfer scenario.

Back at Livermore, the consensus was that with the resources we would have to expend transferring druas, manifesting, transporting, storing, plus the administrative costs and the safety impacts, there would be little gain with the Berkeley strategy. It was at this time that we decided to aggressively pursue the purcnase of our own equipment. 
We went through the normal Lab competitive bid process. Our bid solicitation, began in early 1988, was based on Master Chemical's XYREX 1000 because of favorable teviews from observations at machine tool shows, and because we had become familiar with the equipment through our Berkeley communications. We did research various recycling processes including centrifuge, evaporation, cyclonic, and coalescing plate systems. Dur reseacch pointed to the centrifuge as the best technology to use in a recycling system. In early september, 1988 Bob Accardo. a nember of our organization and part ce our recycling team, visited a southern california $f$ irm to assess their experience with recycling equipment manufactured by clinton Centrifuge. He also contacted another southern Californja Clinton user by phone. In both cases only centrifuge components were used on in-house built systems, and we couldn't verify the performance of a stand alone unit. On September 16, 1988 we awarded the purchase to Master chemical for their XYBEX 1000 recycliug system at $\$ 40,687.00$ which included a rachine sump cleaner. Master Chemical was chosen the successful bidder because they met all the specifications and theiz unit was compatible with products we already use. other bidders never successfully demonstrated they had a unit which would meet the specifications. He took delivery in December and accomplished installation and training in January, 1989. The system became operational on January 18, 1989.

The system we purchased consisted of a skid-mounted unit containing dirty and clean coolant reservoirs, an automatic coolant propoctioning pump, an oil belt

mmer, a high speed centrifuge, electrical controls and PVC plumbing. The pVC 2 used with deionized water because this water is so pure it reacts with metallic pipe or tubing, leeching out minerals. The heart of the system is the centrifuge. This is a Westfalia high speed centrifuge operating at 9000 RPM. I. can remove tramp oil to less than .58 concentration and solid matter to 5 micro: or less. This centrifuge can process 90 gallons/hr. It requires a dedicated cleaning every 8 hours of operation. To augment the XYBEX we also purchased a sump cleaning vacum called the Yellow-bellied sump sucker. This is a twin compartment unit holoing 100 gallons of fresh coolant and room for 100 gallons of used coolant. It is propane operated making it truly portable and has hoses and hookups making the unit compatible with the XYBEX. As part of the regulas maintenance, we send a monthly sample of fresh coolant to Master chemical for analysis. They rax the laboratory report to us showing the concentration, Ph level, bacteria count, Eungal count, and tramp oil percantage. We are especially concerned with the bacteria count because a high bacteria populatian can ruin the coolant we have stored in the system and that in the machines. We do occasionally use a bactericide as a control measure. 
as a first step in the iormal recycling program I envisioned, I sent a memo to all potentential users of our system, discussing the equipment, procedures and some of their responsibilities. He then proceeded to thotoughly clean ali the machine tools in the shop. The Main Bay Machining Facility is approximately 21000 square feet containing 33 major machine tools with 1100 gallons of coolant which required recycling. The schedule I generated grouped close proximity machines together. The cleaning effort took about seven weeks. This was accomplished on a part time basis by 2 employees. The procedure start_d witl the pump out of all the coolant in the machine. This spent coolant was placed in 55 gallon drums and processed through Hazardous Waste Mgmt. There was no attempt to process this initial coolant through the recycler as we had no knowledge of contaminants or bacteria that might be present. Next, all solid material such as chips and sludge was removed from the reservoirs, recesses and avities of the machine. The machine coolant reservoir was filled with a machine cleaner provided by Master Chemical and allowed to circulate for 3-4 hours. During this time the entire machine was thoroughly cleaned. The machine cleaner was pumped out and also processed through HWM. Next a clear rinse of deionized water was flushed through the machine and also pumped out. In the future, we plan to add a germicide to this cycle. Finally the machine was filled with fresh coolant and was ready for scheduled coolant changes and processing through the XYBEX. The machine cleaning effort took 160 hours $/ \$ 8000.00$ which should be considered a start-up cost.

starced regularly scheduled recycling in March and have continued it on a i. .thly basis. The recycling takes about 20 hours over a monthly period. In July we added the MrD Precision shop to the recycling program. This shop is located adjacent to the Main Bay and has 200 gallons of coolant for recycling. We have had inquiries from the MFD optic Lab but their coolant is not compatible with Trim-5ol. As ar additional benefit, our machinists have commented about the excellent quality coolant we have due to regular recycling.

An analysis of the economic issues and payback associated with this effort proved interesting. Dur start-up costs included: XYBEX purchase: $\$ 40,687.00$; training: $\$ 3600.00$; security guard during installation: $\$ 1200.00$; machine cleaning: $\$ 8000.00$; total costs: $\$ 53,487.00$. On the payback 5 ide, HWM costs to process (1) 55 galion drum of coolant: $\$ 14.60 /$ gal or $\$ 803 / d r u m$. MFD costs for sampling: $\$ 50.00$ per drum. Between January and July 1988 we sent (33) 55 gallor drums of coolant waste to Hazardous waste Management. During the same period it 1989 we sent 5 drums, a reduction of $85 \%$.

We are about to incorporate our first area shop into the recycling program. Building 343 High Pressure Lab would like us to service a Hurco Milling ma wine and two smaller machines for a total of 70 gallons. I can see the time when we can no longer service all the machines we are requested because of our limited personnel. I believe at that time, coolant recycling could become a separate entity. As a final note, I feel that Materials Eabrication Division deserves credit for recognizing a problem and impletenting a workable solution. 


\section{DIRECTORATE MINI PLAN}

for

LASERS (LIS AND ICF) 


\section{Laser Programs Waste Minimization Plan}

\section{February 1990}

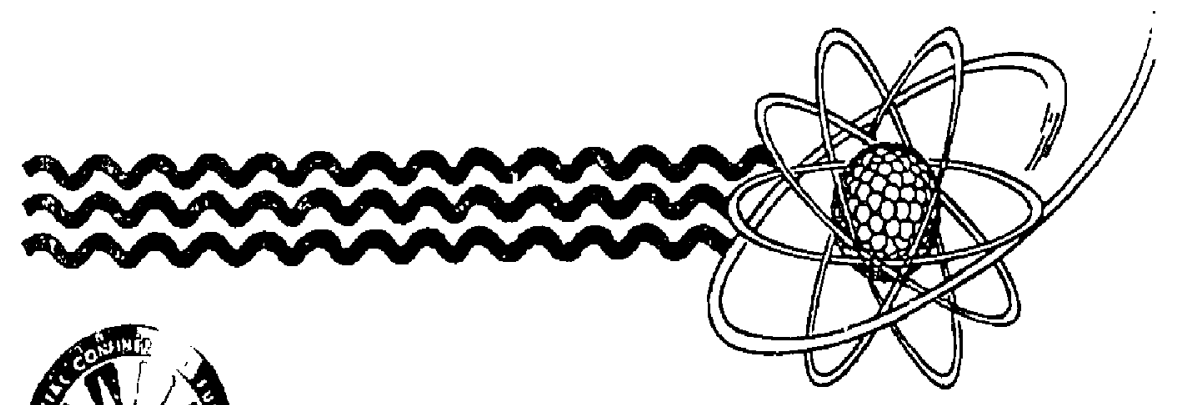

Lawrence Livermors 


\section{Laser Programs Waste Minimization Plan}

\section{February 1990}

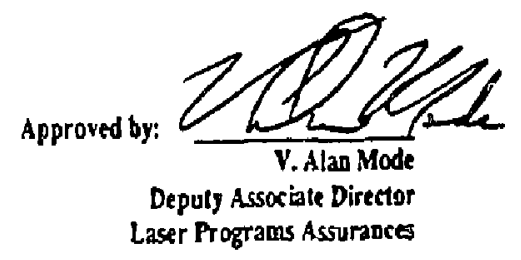

LAWRENCE LIVERMORE NATIONAL LABORATORY

University of California - Livermore, California - 94550 


\section{Contents}

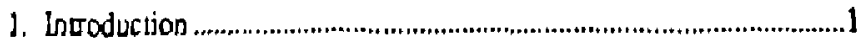

1.1 Need for Plan ............................................................................1

1.2 Purpose and Objectives of the Plan ............................................2

2. Laser Programs Policy on Waste Minimization ....................................5

3. Elements of the Plan .......................................................................... 7

3.1 Top Management Support ........................................................

3.1.1 Training and A wareness .............................................. 8

3.1.2 Responsibilitier ..........................................................

3.2 Characierization of Waste Generation .......................................8

3.3 Waste Mnimization Assessments............................................9

3.3.1 Perfomance Assescments ............................................9

3.3.2 Analytic Assessments ................................................ 10

3.4 Cost Allocation System .......................................................... 10

3.5 Technology Transfer .......................................................... 10

3.6 Program Evaluation ...............................................................

3.7 Quality Assurance ..................................................................11

4. General Guidance on Waste Minimization .......................................13

4.1 Methods Used to Minimize Waste .............................................15

4.2 Responsibilibies and Implementation ........................................16

4.2.1 Laser Programs Office................................................... 16

4.2.2 Line Management .......................................................... 17

4.2.3 Waste Minimization Commitree .....................................17

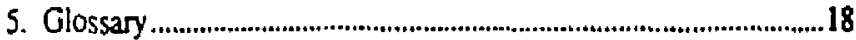

6. References .......................................................................................20 


\section{Atiachment 1 administrative

\section{OIRECTOR'S STATEHENT ON WASTE MINIMIZATION}

It is important that the Laboratory make a strong comitment to waste minimization--particularly to hazardous and radioactive waste minimization. Our goal is to reduce the Laboratory's nazaroous/radiactive waste streams oy a major factor in the next three to ive vears op requcing generation and increasing recycling. We will implement an incentive system where each Laboratory program will pay the costs associated with the hanoling and disposal of its waste. Eaen Drogram will estatlish waste minimization goals and develop plans and assign responsidility for achieving these goais. Haste minimization wiil be incorporated in the desian of new projects.

John H. Nuckolls

Director 


\section{Attachment 2}

\section{Site 300 Resident Manager's \\ Policy Statement on Waste Minimization \\ February 1, 1990}

In accordance with the Director's Policy Statement on Waste Minimization (LLNL Administrative Memo. Volume 19. Number 6) issued on March 8, 1989. and the Nuclear Design Program Waste Minimization Plan currently undergoing final review. Site 300 employees shall incorporate waste minimization in the design and implementation of programmatic and support activities. This policy is consistent with the current Site 300 philosophy of including methods for (1) eliminating or reducing sources of hazardous waste by material. process, or housekeeping controls. (2) recycling wastes through reclamation or reuse, and (3) treating waste to reduce its toxicity and/or volume in all Site 300 experiments and operations. It is our goal to reduce the : olumo of iaazardous and mixed wastestreams generated at Site 300 by at least $25 \%$ civer volumes generated in 1988 in the next three to five years. We intend to accomplish this goal by favoring source reduction and recycling over treatment in existing and future operations.

Each Site 300 program and support organization manager or representative shall establish individual waste minimization goals and plans. The manager or representative shall also appoint a waste reduction coordinator to direct waste minimization efforts in their programmatic or support organization area, ensure that personnel are made aware of waste source reduction requirements, and interact with the Nuclear Design Program Waste Minimization Coordinator. Waste minimization recordkeeping functions shall continue to be the responsibility of EPD's Hazardous Waste Management Division.

The Nuclear Design Program Deputy Associate Director for Assurances Office will provide the system for reviewing and auditing programmatic and support activities to ensure that waste minimization goals are being addressed.

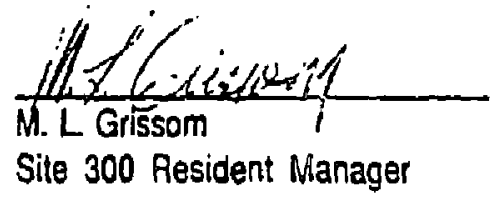




\section{Attachment 3 \\ Waste Minimization Certification}

I certify under penalty of law that this document and all attachments were prepared under my direction or supervision in accordance with a system designed to assute that qualified personnel properly gather and evaluate the information submitted. Based on my inquiry of the person or persons who manage the system. or those persons directly responsible for gathering the intormation, the information submitted is, to be the best of my knowledge and belief, true, accurate and complete. I am aware that there are significant penalties for submitting false information, including the possibility of fine and imprisonment for knowing violations.

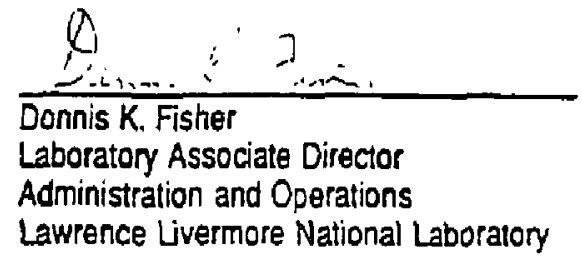




\section{Attachment 4 \\ Waste Minimization Certification}

I hereby certify under penalty of law that, personnel under my direction and supervision, at this facility are undertaking specific steps in accordance with a program in place, to minimize the amount and toxicity of hazardous waste generated at this facility to a degree econimically practicable and that the method utilized for the treatment, storage, or disposal of hazardous wastes is the practicable method currently available to this facility which minimizes the present and future threat to human health and fine environme.?t. I am aware that there are significant penalties for taise cerrification, incluoting the possibility of fine and imprisonment for tlagrant talsitications.

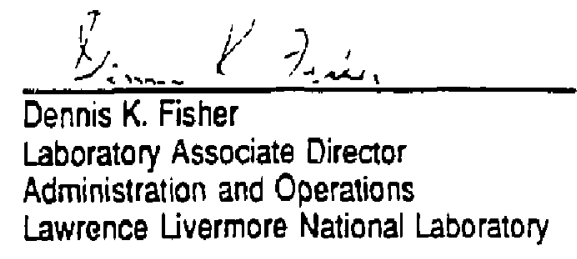


DIRECTORATE MINI PLAN

for

NUCLEAR TEST 


\section{Waste Minimization Plan for \\ Nuclear Test-Experimental Science Program}

January, 1990

\section{Introduction}

In response to the HAZARDOUS and SOLID WASTE AMENDMENTS (HSWA) to the RESOURCE CONSERVAT:ON and RECOVERY ACT (RCRA) $)^{1}$ and to a greater concem for the environment the Nuclear Test-Experimental Science (NTES) Program has reviewed its programmatic and research goals and its operation, and has formulated a plan that will accomplish the mission and minimize waste at the same time. This is in keeping with DOE and LLNL policy to reduce the amount of hazardous waste and to lessen the impact on the environment. This plan relies upon procedures established within L-and Nuclear Chemistry Divisions. The primary components of the plan are education and administrative controls. The narure and volume of wastes generated by the Divisions' operaions will be feviewed on a regular basis. New operations will be screened for waste minimization opions, and successful methods will be shared with all staff.

The Nuclear Test-Experimental Science Program consists of three divisions: Nuclear Chemistry Division (NCD); L-Division; and Nuclear Tesi Operations Division (NTOD). Waste minimization responsibilities rest within each division, and marixed personnel are expecied to be faniliar with the policies of the division they suppor, as well as the policy of their parent organization. This document contains the individual plans only for NCD and L-Division. NTOD is located at Mercury, Nevada, at the Nevada Test Site, and is primarily a scientific administrative organization that suppors the vher two NTES divisions and provides liaison with the other contractors. The amount of hazardous waste generated by NTOD is very small and is handled by the principal NTS contractor, Reynolds Electrical Engineering Company (REECo), whose overall plan is approved by the DOE Nevada Operaions Office.

Waste Minimization Plans

\section{L-Division}

L-Division is under the jurisdiction of the Associate Direstur for Nuclear TestExperimental Science. The Division chiefly supports the programmatic mission of obraining experimental data imporant to understanding the physics of nuclear weapons. W'e design, assemble, and calibrate instruments for application on nuclear tests at the Nevada Test Site (NTS). We also maintain physics laboratories wherein nuclear weapons wuddions may be sinulated ario studied, and where advanced diagnostic development may be accomplished. The Division's physical plant includes electronic and mechanical assembly and calibration laboratories, machine shops, s.Jatl accelerators, $x$-ray generading equipment, laser laboratories, and photo labs. They are located in Building 121 and portions of Buildings 174, 212, 255, and, at Site 300, Building 812B. 
In order to minimize the generation of waste, L-Division will:

1) Establish an inventory of wastes generated.

2) Establish methods to minimize unintentional waste generation.

3) Factor waste minimizacion into experiment processes and plans.

4) Separate wastes where appropria'e.

5) Train personnel to assure that waste minimization concepts are understood.

Effectively all of the routine operations generating hazartous wastes in L-Division laboratories are found in many other facilities at the Laboratory. They involve the use of solvents, laser dyes, phow chemicals, oils, adhesives, ecc. No radioactive or mixed wastes are generated in routine operadions. L-Division will emphasize idencification of w'aste-generating materials and processes; evaluating the use of substitute non-hazardous materials: monitoring and minimizing the inventory of waste-generating materials on hand in the facilities; and waste separativa to enhance recycling and to minimize disposal costs. In these routine operations we will coordinate our waste minimization effors with Laboratory policy established through the Environment, Safety, and Health Council.

Non-routine operapions involving hazardous materiais require formal Operational Safery Procedures (OSP) for their execution. The author will be required to address hazardous waste generation and minimization as par of the description of his operation. The OSP's are reviewed and signed by the Division Leader.

Records of hazardous waste-generating materials and their locations will be maintained on a room-by-room basis and updated periodically. This will allow courdination across the facilites in minimizing inputs to the waste scream from overstocking of such materials. Recyrds of hazardous waste disposal as maintained by the Laboratory's HAZARDOUS WASTE MANAGEMENT GROUP will be used to monitor generation and to demonstrate trends.

The waste minimizavion plan will be communicated to the L-Division staff and its effecriveness will be moritored.

The plan described above, when implemented, will lead to minimizapion of hazardous wastes generated by L-Division. The plan involves commiment by management to inventory controls and to oversight, while maintaining a high level of awareness and responsibility for waste management as the level of the Laboratory scientist, engineer, and technician.

\section{Nuclear Chemistry Division}

The NUCLEAR CHEMISTRY DIVISION (NCD) is under the jurisdiction of the Associate Director for Nuciear Test-Experimental Science. We have a diverse mission: The quantification of rdionuclides produced in nuclear tests, the quantification of radionuclides in the environment, and research in to nuclear properties and processes. The use of both radioactive and hazardous materials is inherent in our wotk. The generation of hazardicus waste, radioactive waste, and 
mixtures of these is inevitable. We will work to identify and adopt new technologies that permit reduction of the amount of warte generated wherever it is both safe and feasible to do so.

In order to minimize the generacion of waste, Nuclear Chemisory Division will:

1) Estabiish ant inventory of wastes generated.

2) Establish methods to minimize unintentional waste generation, e.g., by sharing chemical stocks.

3) Factor waste minimization into experiment and process design.

4) Sepirate wastes where appropriale.

5) Train personnel to ensure that waste minimization concepts are understood

In the NCD, the majority of acrivities that generate wastes involve the use of radioactive materials, chemical reagents, and soivents. Consequently, our waste minimizavion plan will focus on control of chemical inventory and usage and on segregation of radioactive and non-radioactive waste. A: the present we have an inventory of chemicals is each laboratory. By reviewing this inventory we can detemine if there is excessive duplication and work to correct it. We also have established a data base of waste generated by the Division. With this we can compare the amount of waste generated by the Division on a monthly basis. We will also work closely with our stores people in order to maintain control of chemical slocks used. A key ingredient for successful implementation of a plan such as this is training. NCD will provide necessaty training. It is NCD policy that wastes generated in the laboratory will be placed in labeled contain:ars. Efforts will be made to segregate non-hazardous wastes from hazardous wastes, ind to avoid the generation of mixed-waste. However, it has been and will be the practice of NCD to avoid the inadvertent addition of radioactive waste to non-radioactive waste even if this resules in more than minimum amounes of low level radioactive waste. In other words, if there is any question about radioactive content, NCD will consider it to be radioactive waste. Periodic inspections will be cunducted to ensure that minimizarion techniques and waste disposal requirements are being followed. $A \|$ bench top experiments and pilot-scale experimental simulations requiring ar, OSP will be reviewed to detemine if it meets waste minimization standards set by NCD. Any experiment that will generate more than ten (10) gallons or ten (10) pounds of extremely hazardous waste will be reviewed by the Division. A data 'ase of waste generated the last two years has been established. With this and the ir "ormation available from LLNL's Hazardous Waste Management Group we will t 3 able to compare our present waste generation with previous times.

HAZARDOUS

$$
\text { liq } 1 \mathrm{kgl}
$$

1988

1989
727

2180 solid.(kg)

1215

1229
RADIOACTIVE

$\begin{array}{cc}\text { Lif. (kg) } & \text { solid (kg) } \\ 1256 & 3083 \\ 1021 & 7287\end{array}$

We believe that the greater amounts shown in 1989 are due to better record keeping and to the greater number of samples processed. 
The Associare Division Leader for Operaticns through the section leaders will communicate to the NCD saff the proper elements of the waste minimization p!an, and will oonitor its effectiveness.

We believe that the plan described above, when implemented, will lead to minimization of waste generated by NCD. The plan involves commiment by management to inventory controls and to oversight, while maintaining a high level of awareness and responsibility for waste minimizarion at the level of the laboratory scientis:. The 1990 NCD HAZARDOUS WASTE MINIMIZATIO' : GOAL is to reduce the amount of hazardous waste by 5\% based on 1989 reconds.

${ }^{2}$ RCRA secrion 1003(b) as amended by HSQA PL 98-616 
DIRECTORATE MINI PLAN

$$
\text { for }
$$

PHYSICS 
Date: December 3, 1989

TO: $\quad$ Richard Heckman

FROM: Edward English fod

SL'BJECT: Waste Minimization Within Physics

Pbysics supports the Laboratory's concern to assure that processes generate the minimum level of managed wastes. Essentially, this affects our operations in two areas: program suppored engineering area shops and semi-conductor fabrication.

We have asked Engineering to assure that the practices and procedure improvements which they put into effect in their directly managed shops (e.g. MFD) be incorporated within our program sponsored shops. This will affect shops in Buildings 194, 212, and 292.

Within the semi-conductor fabrication area, we have worked with Hazards Control to assure that our processes employ the lowest possible volume amounts of hazardcus materials in the fabrication process in order to maximize our protection of employee health and safety. Furcher, we have incorporated the most efficient research fabrication processes which we could suitable for our purposes. Finally, these actions were all undertaken within the past two years and thus the technology and processes are current. The result is that we do not see how we could improve our process at this time to reduce the volume of wastes. We will keep abreast of technology improvements and make changes as they become cost effective in the futuse. For further information on the specifics of these operations, please contact Joe Simpson within "O",

Physies is also in the process of establishing two permanent waste accumulation areas, one to support operations in Building 212 and the other for Building 197.

ct: Jim Doggett

Roger O'Brien

Joe Simíion

Bruce Tarter

Roger Werne 


\section{DIRECTORATE MINI PLAN}

for

W PROGRAM 


\section{Weaponization Program}

\section{Waste Minimization Plan}

The Weaponization Program at Lawrence Livermore National Laboratory operates facilities in Livermore and at Site 300. The personnel in these facilities support a wide variety of engineering activities for the developmer., of weapons systems.

The Program is actively identifying its waste stream, reviewing methods for reducing the inventory of hazardous and radioartive material, providing employee awareness through training/orientation, funding equipment upgrades, and incorporating administrative controls to ensure the Program's efforts are consistent with the Director's Waste Minimization policy statement. Many of the features outlined in the plan are in place already: some will be modified as we find new ways to improve them.

In general, the Program's activities require a small inventory of hazardous materials such as oils, solvents and hazardous chemicals for machining, cleaning, and assembly operations that take place in our facilities. In recent years, the inventory of these materials, including waste products, has been reduced because of an improvement in housekeeping and some changes in methodology to match the Program's and Environmental Protection Department's changing requirements.

\section{Education}

Educating our employees to the benefits of prudent hazardous materials' minimization and waste product removal is ari extremely important feature in our plan. The group leaders are responsible for assuring that their employees receive training consistent with recommendations from the Environmental Protection and Hazards Control Departments. The group leaders are also responsible for documenting training activities and maintaining the training files. The group leaders will utilize current Environmental Protection Department training courses, distribute related literature and informational tilms to their employees for review, and discuss the subject in group meetings to expand the employees' awareness and encourage their active participation. It is particularly important that the employees understand and appreciate the cost implications and difficulties associated with waste removal. 


\section{Administrative}

Weaponization Program acivities involving hazardous materials are limited in scope by the facilities' safety procedures and special operating safety procedures. It is the group leader's responsibility to review each of these documents as they are drafted, or when they require renewal in ensure that the minimization and hazardous material handling issues are addressed and conform 10 the Laboratory's goals. Changes in process methodology, or choosing substitute materiais are to be considered at this time to further reduce the waste stream.

It is the group leader's responsibility to ensure that minimal hazardous materials are proposed during all aspects of a systems development. Cost considerations for the disposal of the waste products consistent with Environmental Prolection Department requirements. are to be discussed to determine the best choice of materials to meet the minimization goals and to more accurately project the Program's budget. The group leader will also encourage the utilization of alternate system evaluation and assembly methods to achieve the same goals.

Centralizing the procurement of hazardous chemicalsimateriais and oils has merit; however, because the project leams work independently with different requirements and schedules, the coordination efforts may be too cumbersome to be practical. Further review is in order to evaluate this option.

\section{Accomplishments}

We have incorporated several changes in our operations to reduce hazardous materials and improve waste product handling practices in our facilities in recent years. For example, all of our 55 gallon storage racks containing our supply of oils and solvents were removed approximately 4 years ago to reduce the inventory and to avoid the possibility of a large spill. A new system was incorporated wherein our stock of these materials is limited to only that necessary to accomplish the task at nand, wherever possible. The materials, in unbreakable containers, are stored in fire satety cabinets in the work areas and limited to small quantities, typically less than 1 gallon. 
Waste products such as contaminated Kimwipes, rags, commercial absorbant materials, and spent liquids are appropriately packaged, tagged and stored in the facilities' waste accumulation area until processed by Hazardous Waste Management personnel.

In the past 3 years, we have upgraced two closed-loop systems containing hazardous fluids that had the potential to produce large amounts of waste as a result of leaks, or catastrophic lailure. Following design reviews, we established guidetines for improving the equipment's maintenance practices, and funded extensive mechanical upgrades to reduce the risk of a sizable release.

We improved our waste product handling and removal system at both sites by installing waste accumulation areas contorming to the Environmental Protection Department guidelines. Frequent documented inspections are required to record the lacilities' status and activity. Upgrades to the Livermore waste accumulation areas are currently under review to meet the buildings' changing requirements.

\section{Summary}

We believe our plan is a very workable method for assisting us to meet the Laboratory's commitment to reduce the hazardous materials waste stream. Thus far, a great deal of progress has been shown because many of its features have been in place for some time. Modifications of this plan are anticipated to address future situations.

DWH:תm/q0019 


\section{DIRECTORATE MINI PLAN}

for

Z DIVISION 


\section{z Division Waste Minimization Plan}

There are two types of waste generators in 2 Division - the Applied Technology Program and the Technical Information Department assigned to $Z$ Division.

The Appliad Technology Program works on a variety of reimbursable projects which utilize the expertise available at LLNL. Some of the work is done within the B261 complex, and some is done by matrixed personnel in laboratories, on site (including Site 300), but outside the B261 complex. Both of these areas will be addressed with regards to waste minimization.

There is a small machine shop in B261 which uses solvents and cutting oils. We will be doing a number of things to minimize waste in this area. We will look at the list of land ban chemicals and determine if any of the solvents or cutting oils are on the list. If they are, we will find substitutes which are not on this list. We will work closely with the main shops in the B327 camplex to learn how they are minimizing machine shop waste. Where possible, we will incorporate these practices into the 8261 machine shop.

Cleaning solvents are used both in the electro-opticilaser and electronic research projects. Again, the land ban list will be consulted anci substitutes for solvents on the list will be found and used. We will work closely with $Y$ Division laser personnel and the Electronics Engineering Department to learn how they are implementing solvent waste minimization, and will use those techniques in $Z$ Division. In situations where solvent substitutes cannot be found, as may be the case with laser dyes, we will ensure that the waste is properly labeled, segregated from other waste, and recycled, if possible.

For Applied Technology Program experiments which are performed on site but outside the B261 complex, we will work closely with the matrixed organization to ensure compliance with their waste minimization plans.

The environmental impact of new projects undertaken by the Applied Technology Program will be assessed before the project is started. Although we do not have control over what materials Supply and Distribution stock, we do have control over what 
materials are purchased through Z Division's technical coordinators. Material requests will be screened for possible toxic waste to be dealt with latei. Quantities of materials will be limited to just that reeded to complete the project without stockpiling for some future project.

The photographic processing and phototynesetting activities within $Z$ Division primarily produ ie as waste spent developer and fixer. The phototypesetting chemicals are purchased in cartridge form, and are disposed of in cartridge form according to Laboratory procedures. Chemicals used ir. both color and black and white photographic processing are collected in 5 gailon carboys, labelled, and then put in labelled lard cans for disposal. The empty developer and fixer containers are compacted and put into labelled lard cans and disposed of as the chemical itselt. Cotton swabs, Kimwipes, Kaydrys, ... which are used in conjunction with any of the land ban chemicals are collectec in labelled lard cans and disposed of according tw Laboratory procedures. Since most of the phototypesetting and photographic processing equipment used in Z Division is not the same as that used by the Technical Information Department in Core 1 , we will not be able to utilize their learnings on how to minimize these types of waste. We will, however, work with the equipment manufacturers to see if non hazardous waste generating chemicals could be used with their equipment.

Waste minimization starts with educating the employees about good waste minimization practices. Both Z Division employees and those matrixed to $Z$ Division from other parts of the Laboratcry will be informed of this waste minimization plan and any further changes to it.

Wastes generated by any particular experiment and/or photographic or printing process will be placed in prelabeled containers and disposed of according to approved Laboratony procedures. Periodic inspections will be conducted in order to ensure that waste minimization and waste disposal practices are followed. 


\section{Introduction}

The Laser Programs Waste Minimization Plan estabiishes the policy and assigns responsibility for minimizing wastes from Laser Programs operations at the Lawrence Livermore National Laboratory (LLNL). The policy is consistent with the intent of Environmental Protection Agency (EPA) policy, Department of Energy (DOE) requirements, overall LLNL policy, and good waste management pracrices. The policy applies 10 sesearch, lechnology development, en ginee.ing dernonstration, and technology deploymenl activities of the Laser Programs. In pariculas, it applies to the five Programmatic elements under the direction of the Associase Direclor for Lasers: Special Isolope Separation (SIS); Uranium Alomic Vapor Laser Isolope Separation (U-AVLIS); Laser Technology; Inertial Confinement Fusion (ICF), and Advanced Applications (AA). II also applies to the Operations function of the Laser Programs. These accivisies cover a broad range of scientific disciplines, and generate various forms and amounts of hazardous, radioactive, and mixed wastes.

This Plan supplements and provides implementarion guidance for the Laser Programs Waste Minimization Policy Statement issued by the Associare Director for Lasets.' The Plan is responsive 10 the Waste Minimization Policy Satement of the LLNL Director dated March 8, 1989,? and has been wsitten to conform 10 both LLNL guidance and EPA guidelines for waste minimization plans contained in the Federal Register."

\subsection{Need for Plan}

Waste minimization is becoming an increasingly imponant national consideration in many activities, and his concem applies to research and development activities at LLNL. Legislation [e.g., the 1984 Hazandous and Solid Waste Amerdments (HSWA) 10 the Resource Conservation and Recovery Acl (RCRAj] has made it increasingy difficult and expensive to dispose of hazardous wastes. Some wastes (e.g., liquid wastes) have been or will be banned from land disposal entirely. Restrictions on waste disposal have resulted in a reduction in the arailability of sites that can . accepi waste. Overall waste disposal cosis have gone up significantly and are expected to continue to increase in the coming years.

In parallel with the growing constraints on wasic disposal, there is increasing official pressure from govermments (federal, slate, and local) and from regulatory agencies (EPA, statc, elc.) on wasie generators to 
seduce the quantities of waste generated. In the 1984 Hazardous and Solid Waste Amendments 10 RCRA, Congress established the follow ing policy:

"The Congress hereby declares that it is to be a national policy of the United Slates that, where feasible, the generation of hazardous waste is io be reduced or eliminated as expeditiously as possible. Waste material generated should be treated, stored, or disposed of so as to minimize the present and furure threat to human health and the environment."

In addition, HSWA required that hazardous waste generators establish a waste progsam and certify on their waste shiprnent manifests that such a program is in place.

In 1988, DOE issued Otder 5820.2A, Radioacrive Waste Monagement and implementation guidance, which required that DOE facilities develop and implement waste minimization plans.s. Also in 1988, DOE issued order \$400.1, General Environmensal Protection Program, which required that each DOE facility prepare a waste minimization program, with goals for minimizing the volume and/or toxicity of all wastes generated, with annual renluctions if programmatic requisements allow.' In 1989, EFA published guidance on the elements of a waste minimizarion program' Also in 1989, EPA made it clear that having a waste minimizasion plan in effert at LLNL was a necessary condition for renewal or issuance of further permits for waste veatmenl at LLNL'

\subsection{Purpose and Objectives of the Plan}

LLNL is preparing a waste minimization pian covering activities at both the Livermore Site and Site 300, a draft of the plan was issued in 1989. (Ref. 9) All LNL programs, including Lasers, are required to prepare individual program plans or mini-plans for inclusion in the overal! LLNL Plan.

This Laser Programs Waste Minimizarion Plan is intended to te used not only as an insen to the overall $L N L$ Waste Minimization Program Plan but also as a stand-alone guidance document for use by the Lases Programs ar LLNL.

The Laser Programs Wasle Minimization Plain is intended to be flexible and adaptable in order 10 address the diversify of projects within the Laser Programs. For current operations, the armounts and characteris. tics of wastes generaled are to be defined, generators identified, processes described, waste minimization alternatives identified, and waste minimization activities implemented. The Plan incorporates three principal overall objectives: (1) to instill in Laser Programs personnel a continuing 
awareness of the imponance of waste reduction in program activities; (2) 10 consider waste minimization in the advance planning of new projects or activities, and to try to incorporate waste minimization considerations in the design and operation of new activities; and (3) 10 achieve overall net reducions in the levels of waste generated by the Laser frogrems as a funcion of the level of program aclivity. At lie same time, the Plan recognizes that, in some instances, wastes may actually increase. When (Cnew projects are slared, whenexisting projects are expanded or thanged, (3) when major demonstrations are conducted, or whethew cxperimenis are added, the absolute level of wasies generated may inctease on an interim basis. Norwithstanding the fact that this plan recognizes that, for certain projects, absolute quanivies of waste generated from a given program area max iemporarily increase, the plan requires that such activities be planned and conducted $1 \pi$ tananner to minimize the waste generated 10 the exient that it is environmentally and programmatically practical.

This Laser Programs H'asse Minimization Plan is incended to be used to suppon ongoing and planned Laser Programs accivities including operarion of the Nova laser, the Laser Demonsuarion Facility (LDF), the Enginecring Demonsozation System (EDS), and UDS, as well as selected suppor activities including analytical laboratories. 


\section{Laser Programs Policy on Waste Minimization}

February 5, 1990

\section{LASER PROGR, ATS POLICY STATENENT ON HASTE MINIMIZATION}

Laser Programs is stongly committed to minimizing the generation of hazardous and sadioacive wastes in Laser Programs activities. Its goal is to minimize hazardous and radioactive waste streams through careful planning, reduced generation, increased rexycling, process changes, employee aw areness and administrative controls.

Each major program or projeci should establish waste minjmization goals, develop plans, and assign responsibilities for achieving these goals. A waste minimization committe, with members from each Laser Programs element, will provide guidance and monilor progress. The success of waste minimization will depend on active paricipation and contribution from every member of Laser Programs. New projects wjll incorporate waste minimization considerations in their design and operations.

The Laser Programs' effon supports the Director's starement on Waste Minimization.

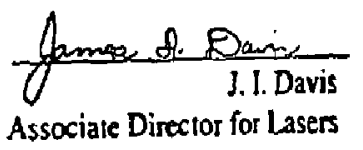




\section{Elements of the Plan}

There are seven elements to the Laser Programs Haste Minimizorion Plan:

- Top management support

- Characterization of waste generation.

- Waste minimization assessments.

- Cosi allocajon system.

- Technology tansfer.

- Program evaluation.

- Quality assurance.

The Plan is intended 10 address applicable DOE $E^{96}$ and $E P A^{3}$ guidance. It follows the EPA format suggested in Reference 3, which contains the first six elcments above. The seventh clement, quality assurance, has been added to highlight the imponance of the QA function for waste minimization and to addess explicitly a DOE requirement.

\subsection{Top Management Support}

Laser Programs management has placed waste minimization in program activities as a high priority. In 1989, the Program Leader of the Laser Isolope Separation (LIS) Program assigned personnel to begin work on a waste minimization program for LIS. A parallel effort was also initiated in the ICF Program. In early Sepiember 1989, the Associate Director for Lasers called a meeting of Laser Programs managers to discuss the importance of compliance with applicable hea'th, safery, and environmental requirements, including waste considerations. The following week, as part of a Laser Programs reorganization, he established at the Deputy Associate Director (DAD) level an Assurances function with responsibility for development and oversight of a waste minimization program for the Laser Programs.

Other manifestations of top management support for wasie minimization include the following:

- Issuance of a Laser Programs Policy Statement on Waste Minimization (February 1990).

- Membership on LLNL Waste Minimizarion Steering Commintee : (starting in May 1989).

- Establishment of a Laser Programs Waste Minimization Committe (January 1990).

- Establishment of a Waste Manager position ror the Laser Programs (December 1989). (Ref. 10) 
- Obtaining concract suppon for waste management and waste minimization (October 1989).

- Scheduling waste management toining for over 300 Laser Programs personnel (August 1989).

\subsubsection{Training and Awareness}

Laser Programs personnel, from tnaragement to operalots and including conractors, must be aware that waste minimization is par of everyday business and is everyone's concem. Employee awareness of waste minimization may range from what they rad in the Laboratory nes'spaper 10 mandalory attendance ar fomal training sessions and to specific information contained in guidance cucuinents. All Lasef personnel handling feed materials or saste streams, or involved in process operations are required 10 attend formal taining sessionj. Traditionally, formal trainiag sessions have been conducted by the Environmental frotection Deparment (EPD). For example, selected Laser Programs personnel were recently trained in "Hazardous Waste Handling." Other classes available through EPD are "Guidelines for Waste Accumulation Areas" and "Prepa. ration Guide for Generators of Hazardous Cherricals and Radioactive Waste at LLNL" An allendance record is maintained 10 assufe that all personnel receive appropriate raining, with periodic refresher classes as needed. Waste minimization information from the pubiished literature, vendor information, or rade shows is disseminaled through informal briefings by managers or supervisors.

\subsubsection{Responsibilities}

Laser Programs management, beginning with the Associate Direclor, is commilled to the achievement of waste minimization objectives and compliance with applicable environmental requirements. In particulas, the Laser Programs subscribe to the statement about waste minimization in the LLNL Environmental Policy Satement," which makes smong support for waste minimization a Laboratory policy.

The Associate Director for Lasers holds his deputies and subordinate managers responsible for implementation of this Plan and of the Laser Programs Policy Statement on Waste Minimization:

\subsection{Characterization of Waste Generation}

Data on waste geserated by the Laser Programs is captured in a data base maintained by the Hazandous Waste Management (HWM) Division of 
the EDP. In 1989, the Laser Programs requested several reports from this data base on selected program activities for analysis of waste generation forms, quantities, locations, and generators. In 1989, this effort focused on coppici and process laser operations.

In 1990, the Laser Programs wasie characierization effor will be expanded to the entire Laser Programs. The other Laser Programs whose waste generation forms, levels, and patterns will be characterized are the non-laser portions of the U-A VLIS and SIS Programs, the ICF Program, and the Advanced Applications Program. In addition, waste generation dara for coppet and process lasers in the Laser Technology Program will be updated.

Also in 1990, anticjpated waste generation levels for the planned EDS and UDS demonstrations will be characterized and waste minimization considerations will be factored, as practical, into plans for the design and operations of these demonstrations.

\subsection{Waste Minimization Assessments}

\subsubsection{Performance Assessments}

The Laser Programs initiated a program of waste management assessments in 1989. An Assessments Manager position has been created and staffed in the Laser Program Assurances office, and the focus of work in this position to date has been on waste management practices in the Laser Programs. The Assessments Manages prepares reports of his findings and line management is tasked for corrective action. Corrective actions are subsequenty reviewed for adequacy. In 1990, this ongoing assessment effort will be supplemented by contract help with expertise in waste minimization. In addition, there are multiple surveillances, assessments, and appraisals of laser waste maragement practices performed by the LLML Envionmental Prolection Department and Hazands Control Department. The findings are conmunicated to the Laser Assuances Otganization and to cognizant line managers who are responsible for corrective action. A responsibility of the Laser Program Wasie Manager position will be to develop and oversee waste minimization assessments; and 10 maintain records of waste minimization assessments conducted. ;

An Assurances data base containing information on a broad range of internal and extemal health, safery, and environmental appraisals will be established in 1990. This data base will tacilitale both the program assessme't and the prograrn evaluation (see Section 3.6) functions. 


\subsubsection{Analylic Assessments}

In addition, one of the responsibilizies of the Laser Programs Waste Minimization Commiltee will be 10 perform waste minimization analyses of selected program activities. Included in these analyses, assessments will be performed to track materials that end up as waste from the time of receipt, if possible, to the point at whici they becoms a waste. Pan of the incent of these broad assessments will be 10 identify targets of opponunity al points in a process where materials can be prevented from becoming a wastc (c.g. by using less material, recycling, finding substitutes, or making equipmenl changes).

\subsection{Cost Allocation System}

Lase: Programs representatives on the LLN, Waste Minimization Sieering Committee were very active in helping develop a proposed Laboratory-wide recharge system for waste generators in FY89. The LLNL recharge system, targeted for implementaion on October 1, 1989, has not been implemented because of expected changes in the DOE waste management program, which would cause waste management functions at DOE sites to be funded directly as a j. Jgram by DOE.

Because cost is an important factor in waste management efforts, the analytic wasle minimization assessments described in Section 3.3 .2 will include waste management costs as a consideration in developing suggesions for improvements in waste ninimization.

\subsection{Technology Transfer}

Exchange of technical information on waste minimization is an important constituent of the Laser Programs Waste Minimization Plan. In 1989, such exchanges were fosiered through the following avenues:

- Participation of Laser Programs personsel in Laboratory-wide waste minimization activinies (e.g, memberships on LLNL Waste Minimization Steering Committec).

- Participation of Laser Programs personnel in DOE-wide waste minimization activities [e.g. membership in reduced waste generation working group of the Malerials Management Exchange Committee (MMEC)].

- Formation of a Waste Mirimization Conmittee within the LIS Program with representation from each major lechnology area.

- Attendance at professional mectings on waste managemeul and environmental prolection. 
- Hiring consultants with taaste minimization expertise.

- Sponsoring the development of new or modified technology to help reduce identified wasie sureams.

- Frequent contact with the technical staff of the Envionmental Pro. tection Department and its Hazardows Waste Management Division.

All of the above avenues for technology transfer will continue in 1990. The LIS Waste Minimization Committee has been expanded and reorganized as a Laser Progtams-wide commintee.

\subsection{Program Evaluation}

The Laser Programs Waste Minimization Plan is subject to several Jevels of progiam evaluation. They include:

- Performance assessments by the Assessment Manager.

- Evaluation of program implementations by Waste Minimization Committec.

- Oversight by the Laser Assurances Office.

- Reviews and assessments by the Environmental Protection and Hazardous Control Deparmenis.

- Reviews and assessmenis by DOE.

- Annual Laser Programs inpul to annual LLNL summary of waste reduction activities (subminod as an appendix 10 the $L N L$ Waste Management Plan by the LLNL Waste Program Manager).

All these types of revisw and evaluations are expected to take place in 1990.

\subsection{Quality Assurance}

The constiruents of the Quality Assurance Program for waste minimization are incorporated in the waste minimization elements described above. For ease of reference, they are listed below:

- Waste Minimization PJans.

- Managemeni suppor.

- Oversight by Assessment Manager, Laser Programs Waste Minimization Commitac, Laser Assurances Office, and by Hazards Contol and Environmental Protection Deparments.

- Compliance data base.

- Conective action. 


\section{General Guidance on Waste Minimization}

Over a period of ame, a hazardous waste management hierarchy has evolved and has been accepted as a standard by waste management experts (see Table 1).' The hierarchy recognizes a range of practices and rechnologies to reduce waste generation. The priority system embodied in the hazardous waste management hierarchy has been adopted by the Laboratory. The highest prionity is 10 reduce the generation of all wastes al the sourre-source reduction. All wasies have some potential for source reduction through such ac ivities as gond housekeeping practices, product changes, chernical subsriution, and process changes. The second priority is to recucle remaining wasses wherever possible. Both off-sile and on-site recycling have been applied to such wastes as solvents, oils, metals, acids, and empry containers. Third, wastes which cannor be eliminated or recycled may te reared to minimize the volume.

Laser personnel should use the standard hierarchy, evaluating the appropriateness of each method and selecting those which are suitable. Some are being adopted; others have already been incorporaled.

The success of source reduction within Laser Programs will depend on personnel becoming better educated and more conscious of environmental issues. The leaming process and implementation will follow an orderly phased progression which has been successful in similar (commercial, induscrial) off-site applications. Good housekeeping, the first step, generally produces significant reductions at small costs. Following this initial phase, formal operating procedure improvements produce additional waste reduction. The third phase is process modifications or changes, wherein new equipment may be installed and/or actual process stream components are changed or modified. This third phase usually requires significant engineering effort, capital equipment investment, and possible building modifications-all requiring significant expenditure of both time and money. 


\begin{tabular}{|c|c|c|}
\hline Methods & Activities & Waste streams \\
\hline $\begin{array}{l}\text { Source reduction } \\
\text { (highest prionity) }\end{array}$ & $\begin{array}{l}\text { Good housekee ping praclices } \\
\text { (production management) } \\
\text { - Training } \\
\text { - Waste stream segregation } \\
\text { - Inventory contol } \\
\text { - Employee involvement } \\
\text { - Spillheak prevention } \\
\text { Product change } \\
\text { (swiching lo products that are } \\
\text { less tazardous to produce) } \\
\text { Chemical substitutiois } \\
\text { (substituring less hazardous } \\
\text { chemicals) } \\
\text { Technology modificalion } \\
\text { - Improved production } \\
\text { management (reducing spitls, } \\
\text { leaks, evaporation, mixnure } \\
\text { errors, and bad product nuns) } \\
\text { - Process change } \\
\text { (production changes resulting in } \\
\text { less and/or safer chemical use) } \\
\text { - Equipment changefredesign } \\
\text { - Energy/water conservation }\end{array}$ & $\begin{array}{l}\text { All wasles have some } \\
\text { porential for source } \\
\text { reduction }\end{array}$ \\
\hline $\begin{array}{l}\text { On-siteloff-sile } \\
\text { recycling }\end{array}$ & $\begin{array}{l}\text { - Reuse } \\
\text { - Reclamation }\end{array}$ & $\begin{array}{l}\text { Solvents, oils, metals, } \\
\text { acids, developers, } \\
\text { empty containers }\end{array}$ \\
\hline $\begin{array}{l}\text { Treatment } \\
\text { (lowest priority) }\end{array}$ & $\begin{array}{l}\text { - Neutralization } \\
\text { - Precipitation } \\
\text { - Filluation } \\
\text { - Evaporation } \\
\text { - Incineration }\end{array}$ & $\begin{array}{l}\text { Acids, bases, } \\
\text { cyanides, plating } \\
\text { wasies }\end{array}$ \\
\hline
\end{tabular}

Table 1. The hazardous waste management hierarchy. 


\subsection{Methods Used to Minimize Waste}

The methods used to minimize waste usually fall into one of the following categories:

- Improve housekeeping practices.

- Segregare wastes.

- Reduce wastewater flows.

- Change materials purchasing and methods.

- Substitute léss toxic materials.

- Change production methods.

- Delist wastes that are not loxic.

- Recycle or reclaim wastes.

- Treal waste to reduce volume and/or toxicity.

The furs four calegories are rypical good housekeeping practices.

Sloppy housekeeping gcnerally results in excess waste generation; good housekeeping lends to minimize waste generation. For instance, chemical leaks from a pump because of impluper maintenante procedures may result in a large volume of waste, which includes the chemical itself and possibly a larger volume of other chemicals and maierials used in the cleanup. Leaks may be kept at a minimum through proper and periodic scheduled mainienance.

Waste segregation provides many benefits. For instance, when a hazardous waste is mixed with a non-hazardous waste, the mixture becomes hazardous. Through segregation, only the hazardous waste is generated. Similarly, segregation of two hazardous wastes where each is recyclable is prefered to nixing them into a non-recyclable hazardous mixiure.

Processes using rinse waters may be modified so that a smaller volume of more concentrated rinse waler is generaled. Useful materials may be recovered more economically from the concentrate.

Volume and toxicity of wastes may be controlled through front end materials purchasing and control. Fewer types of chemicals purchased in bulk effectively reduces the range of wasies produced and the number of chemical containers that must be disposed. A smaller chemical and material inventory reduces the amoun of expired shelf-life chemicals sent to disposal.

Substitution of less loxic or non-loxic chemicals in the feed streams effecively reduces the toxicity of waste streams. Other benefits are improvements 10 operators' health and safety. Changes in producrion methods or processes are typically the most difficult to implement because of conversion costs and perturbations in operations, but, if well planned and 


\begin{tabular}{|c|c|c|}
\hline MEIHODS & ACITVITES & WASTIE STREAMS \\
\hline$\frac{\begin{array}{c}\text { SOURCE: } \\
\text { REDUCITON }\end{array}}{\text { (highest priority) }}$ & 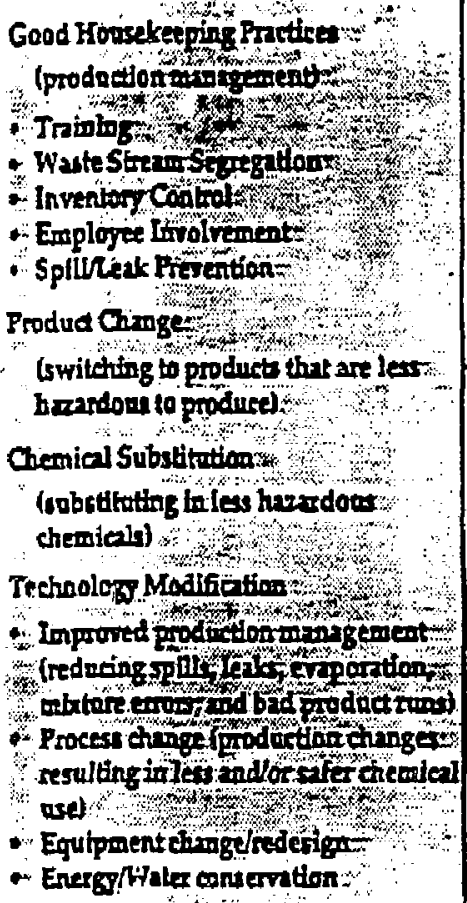 & $\begin{array}{c}\text { Ail wastes hare } \\
\text { some potential } \\
\text { for source. } \\
\text { reduction }\end{array}$ \\
\hline $\begin{array}{l}\text { O:1-STIEOFF-SITE } \\
\text { RECYCUING }\end{array}$ & $\begin{array}{l}\text { - Rense: } \\
\text { - Reclamation }\end{array}$ & $\begin{array}{l}\text { Solvents, oils, melats, } \\
\text { acids, developers, } \\
\text { empty, containers }\end{array}$ \\
\hline $\begin{array}{l}\text { TREATMENT } \\
\text { (lowest priority) }\end{array}$ & $\begin{array}{l}\text { - Neutralization } \\
\text { - Precipitation } \\
\text { - Filtration } \\
\text { - Evaporation } \\
\text { - Incineration }\end{array}$ & $\begin{array}{l}\text { Acids, bases, cyanides, } \\
\text { plating wasles }\end{array}$ \\
\hline
\end{tabular}

Figure 2

Waste Minimization Strategy 
Tables la, Ib, and Ic displays proposed and implemented Site 300 waste minimization astivities for the three wastestreams described above. Reduction activities for each wastestream is receiving high management pricity and will be undertaken to the degree determined to be technically teasible and economically practicable.

\section{Cost Allocation System}

HWM has been studyirg the leasibility of implementing a hazardous wasie cost recharge system for all LLNL program and suppon organizations, and is discussing lunding and implementation issues with LLNL program and support groups and the DOE. After these lunding and implementation issues are resolved, the approved LLNL system shall be implemented at Site 300.

In addition, DAD/ND is evaluating positive incentive alternatives 10 reward those employees and/or yroups who suggest waste reduction lechniques that are adopte. as part of the Site 300 Waste Minimization Program.

\section{Technology Transfer}

Site 300 programs and support organizations interact with other DOE, trade, and academic organizations to obtain information on waste reduction technologies and strategies through the ND Waste Minımization Coordinator. A conscientious eftort is made to network with those organizations who have common waste reduction needs. Within Site 300. information related to waste reduction techniques is maintained in the Site 300 Administration Librany (Building 874, foom 115).

Waste minimization techniques and stracegies developed and implemented at LLNL Site 300 are transferred via established DOE information transfer systems, through professional publications, and through presentations at technical conferences. 


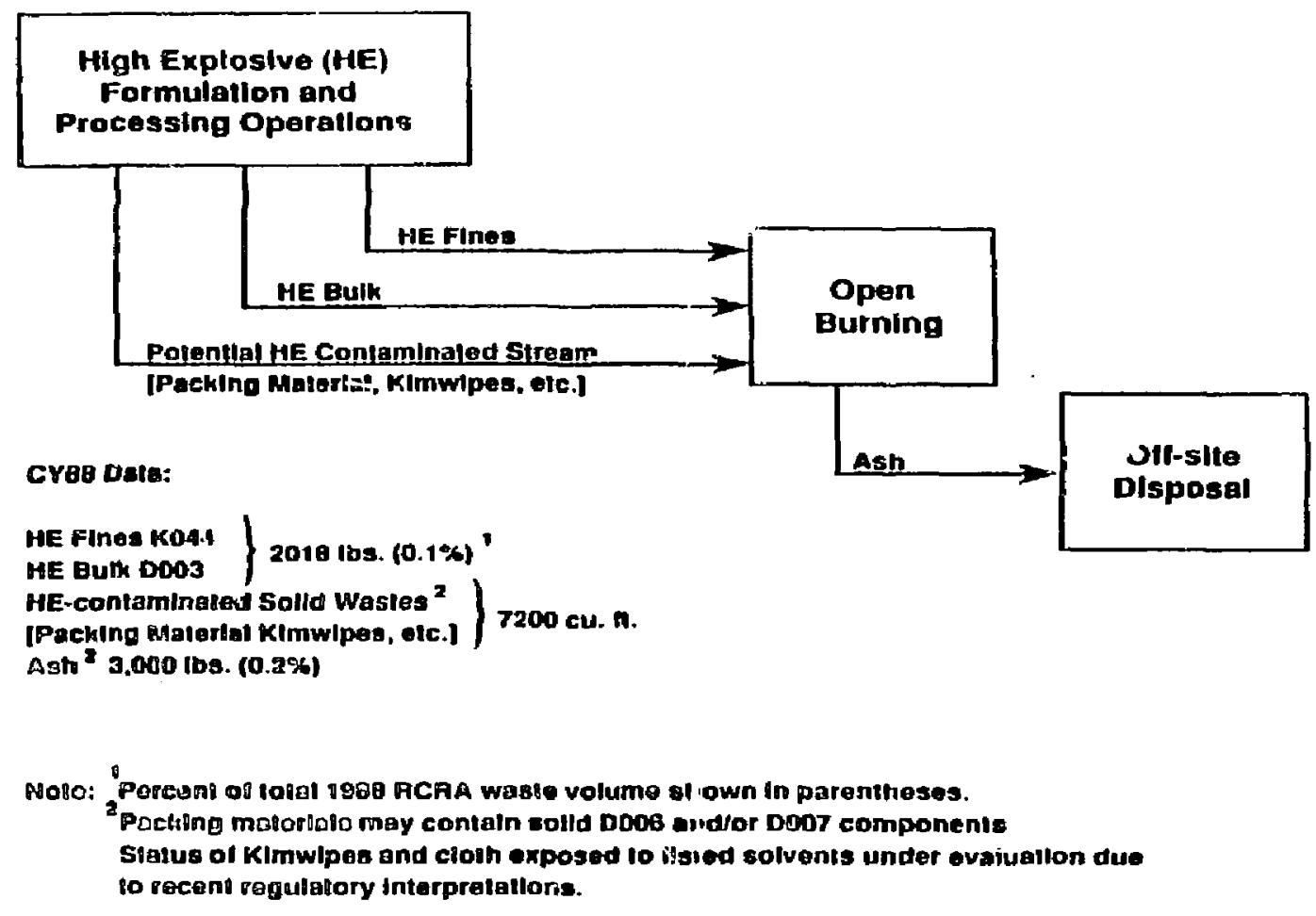

Figure 3a. Wasto Generatton Data 


High Explosives Tesing

\section{Cr8e Date [based on Inpul]}

$$
\begin{aligned}
& \begin{array}{l}
\text { Gravel, } 375 \mathrm{yd}^{3} \times 2564 \text { lbs/yd" }=961,500 \mathrm{lbs} \text {. } \\
\text { Wood } 85 \mathrm{yd}^{2} \times \text { B24 lbsyd, }=70,040 \mathrm{lbs} \text {. }
\end{array} \\
& \text { Plaste' os yd } \times 400 \mathrm{lbaryd}^{3} \text { - 34,000 lbs. }
\end{aligned}
$$

Total Debrts

[Doce + Low - Level Redioncilve] $\overline{1,085,540 \text { los. }}(57.7 \%)^{2}$

\section{Nolog:}

- Poreeni of lotal 1980 RCRA waste volume thown in pareninesls

Figure 3b. Waste Generatton Data 


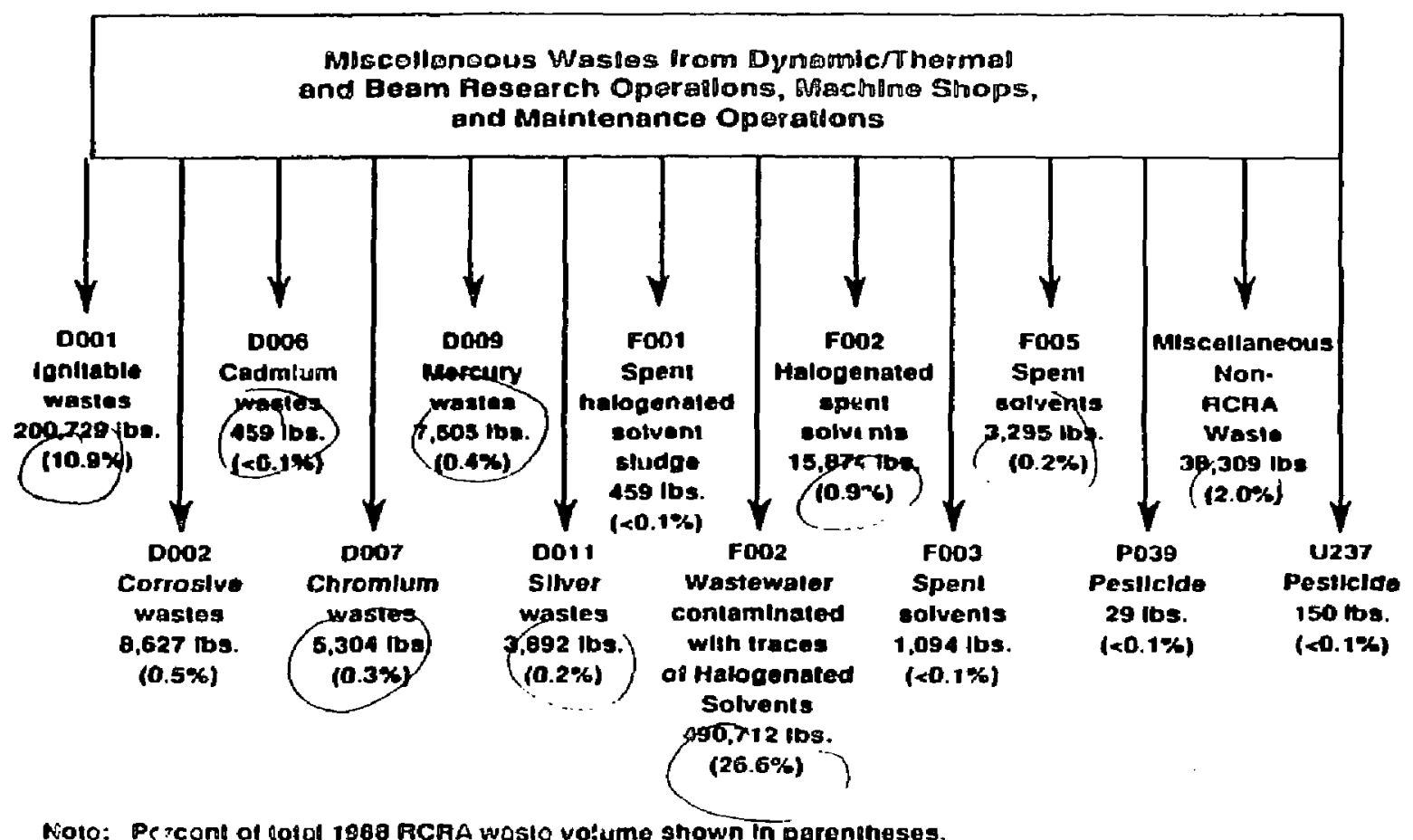

Flgure 3c. Waste Generatlon Data 
Table 7. .

MIgh Explosive (HE) Formulation and Processing Wastes

\begin{tabular}{|c|c|c|c|c|}
\hline Process waste & Minimizatlon proposal & Cost & Schedule & Comments \\
\hline HE IInes & $\begin{array}{l}\text { Pecycle HE lines on-site for reuse } \\
\text { in high explosives tesing } \\
\text { operatlons. }\end{array}$ & $\begin{array}{l}\text { To be } \\
\text { evaluated }\end{array}$ & CY90 & $\begin{array}{l}\text { Technology modilicalion, } \\
\text { process changes required. }\end{array}$ \\
\hline HE bulk & $\begin{array}{l}\text { Technology modiflcatlon, } \\
\text { productlon changes. }\end{array}$ & $\begin{array}{l}\text { To bo } \\
\text { evaluated }\end{array}$ & Creo & $\begin{array}{l}\text { Trainin, and procedure } \\
\text { impleritentation required. }\end{array}$ \\
\hline $\begin{array}{l}\text { HE-cor.jaminated } \\
\text { solld wastes } \\
\text { (packing } \\
\text { matarlal, } \\
\text { Kimwipes, otc.) }\end{array}$ & $\begin{array}{l}\text { Good house keeplng pracilcas, } \\
\text { waste stream eegregatlon, ireining, } \\
\text { inventory conirol, and gplil } \\
\text { provemtion. }\end{array}$ & $\begin{array}{l}\text { Acceptable } \\
\text { coats }\end{array}$ & CY90 & Tre'ning required. \\
\hline
\end{tabular}


Table $1 . b$

Debris from HE Tesis

\begin{tabular}{|c|c|c|c|c|}
\hline Process waste & Minimizallon proposal & Cost & Schedule & Comments \\
\hline \multirow[t]{2}{*}{ Debris } & $\begin{array}{l}\text { Malerials substitution, using } \\
\text { non-hazerdous majorlals in plece } \\
\text { of hazardous materilel. }\end{array}$ & Acceptable & $\begin{array}{l}\text { Inillated } \\
\text { In CY89 } \\
\text { (on-going) }\end{array}$ & 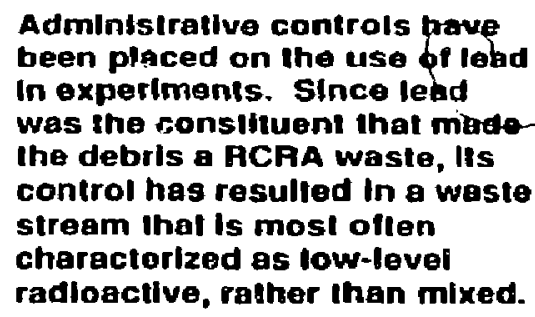 \\
\hline & $\begin{array}{l}\text { Technology modificallon on design } \\
\text { of firdng fable lents }\end{array}$ & Accoptable & $\begin{array}{l}\text { In-place } \\
\text { CY89 }\end{array}$ & $\begin{array}{l}\text { New type of structure used, } \\
\text { resulting in a significant } \\
\text { reduction in the volume of } \\
\text { waste generaled. }\end{array}$ \\
\hline
\end{tabular}


Table $0 . c$

Hisceflaneous Wastes from Dymamic/Thermal and Beam Research Operailons, Machine Shops, and Maintenance Operations

\begin{tabular}{|c|c|c|c|c|}
\hline Process waste & Minimizalion proposal & Cost & schedula & Comments \\
\hline Ignitable waste & $\begin{array}{l}\text { Good housekeeplng practices, } \\
\text { iraining, employee involvement, } \\
\text { waste stream segregatlon, } \\
\text { Invertory control. }\end{array}$ & Accepliuble & Crgo & Treining requilred. \\
\hline Halogenated & $\begin{array}{l}\text { Chemical substilution, process } \\
\text { changes, proquction technology } \\
\text { moditicalion. }\end{array}$ & $\begin{array}{l}\text { To be } \\
\text { ovatuated }\end{array}$ & $\begin{array}{l}\text { Initiale } \\
\text { in CY90 }\end{array}$ & $\begin{array}{l}\text { Studles required to ascertaln } \\
\text { technical feaslbllity, adverse } \\
\text { Impacts on product qually. }\end{array}$ \\
\hline Milscellenodus & $\begin{array}{l}\text { Good housekeeping pracilces, } \\
\text { weste stream segregatlon, splll } \\
\text { prevenllon, inventory control }\end{array}$ & Acceptable & Cr9o & Training required. \\
\hline
\end{tabular}


Program Evaluation and Audits

The DAD/ND snali establish a Quality Assurance Program to audit the implementation of the Site 300 Waste Minimization Plan. A repon shall be prepared to document annual progress on meeting reduction goa's and to identify potential areas for improv'd waste minimization. 
justified on technical and cost-bentfil bases, they can offer substanjal waste reduction potential.

Waste recycling not only reduces the amount of waste that must be sent 10 disposal, but also the amount of virgin materials purchased. Laser Programs wastes that must be trealed are sent to the Hazardous Waste Management Division.

A more general description of these methods as well as examples of their application are found in Reference 4.

\subsection{Responsibilities and Implementation}

It is incumbent on each person working in the Laser Programs to endeavor ic minimize the hazardous or tadioactive waste that may be generated as a result of activices in which he or she is involved.

All operations with hazardous materials requirc an Operaional Safety Procedure (OSP) that must be approved by program management. All Laser Programs OSPs are required to have a section discussing wastes generated from operaions and steps taken 10 minimize such wastes. OSPs approved prior to the issuing of a formal $\angle L N L$ Waste Minimizotion Pro. gram Plan will be required 10 add a waste minimization section by the next ansual review.

The overall goal is lo reduce the volume of waste generated over the next several years when considered as a function of the overall level of program activity. Using the general guidance provided by this plan and by the Laboratory, each directorale, program, project, or activity, as appropriale, shou!d define is own waste mirimization goals. Responsibilities at each level are described below.

\subsubsection{Laser Programs Ofice}

Waste minimization responsibilities of the Laser Programs Office are the following:

- Issues Laser Programs Policy Statement on Waste Minimization.

- Issues and updates Laser Programs Waste Minimization Plan.

- Conducss waste minimization performance assessments, maintains records.

- Oversees waste minimization training, keeps training records.

- Chairs Laser Programs Waste Minimization Committee.

- Is the point of contact with other organizations oft waste minimization (e.g., DOE, EPA, LLNL's Environmental Protection Depass. ment and Hazards Contol Department).

- Approves specific waste minimization plans. 


\subsubsection{Line Management}

Waste minimization responsibilities of line management are the following:

- Implements Laser Programs waste minimization policy and plan.

- Sets goals for waste minimizacion in their programs.

- Assigns responsibilities and allocates resources to achieve the waste minimization goals.

- Considers waste minimization objectives up front in new projects and selects process altematives that contribule to achieving waste minimization goals.

- Develops specific hasie minimization plans for major programs and projects under their cognizance (e.g. U-AVLIS, Laser Technology, UDS, EDS).

- Appoints representatives 10 Laser Programs Waste Mininization Committee.

\subsubsection{Waste Minimization Commilte}

Waste minimization responsibilities of the Waste Management Commillee are the following:

- Reviews and tecommends a aproval of specific waste minimization plans prepared by line organizations.

- Evaluates implementation of the overall Laser Prograns Waste Minimizarion Plan and specific waste minimization plans prepared by line organizations.

- Evaluates candidare waste minimization proposals, including process changes.

- Conducss waste minimization analytical assessments.

- Provides advice and guidance 10 Laser Programs line organizaticas on vaste minimization. 


\section{Glossary'}

AEA: Alomic Energy Aci of 1954, as amended. Establishes requirements for managing radioactive materials and waste.

EP 4: U.S. Environmental Protection Agency. Federal Agency responsiole for enforcing environmental laws. Althcugh some of this responsibility may be delegated to state and local regulatory agencies, EPA retains oversighi authonty to ensure protection of human health and' the environment. EPA administers the Comprehensive Environmental, Response, Compensation, and Liability Act (CERCLA), or Superfund, as it is commonly known, and works with state and local agencies to provide technical oversight :or cleanup activities at federal facilicies regulated by the Superfund program.

EPD: Environmental Prolecion Department (LLNL).

Hazardous wastes: wastes exhibiting any of the following characteristics: ignitability, corrosivity, reactivity, of EP-10xjcity (yielding toric constituents in a leaching test). In addition, EPA has listed as hazardous other Hastes that do not necessarily exhibit these characteristics. Although the legal definition of hazardous waste is complex, the term more generally refers to any waste that EPA believes could pose a threas to human health and the environment if managed improperly. RCRA regulations set strict controls on the management of hazardous was:es.

HSWA: Hazardous and Solid Waste Amendments of 1984 to RCRA. These amendments to RCRA greally expanded the scope of hazardous waste regulation. In HSWA, Congress directed EPA 10 tale measures 10 further roduce the risks to human heatth and the environment caused by hazardous wasles.

IFWM: Hazardous Waste Management Division of the Environmental Prolection Department (LLNL).

Land Ban: a regulatory program that identifjes hazardous wastes that are restricied from land disposal. The regulations incorporate a phasing-in of restrictions in three stages. 
LLW: low-level radioactive waste.

NEPA: Naional Environmental Policy Act of 1969. A iederal statute that imposed the first requirements on federal agencies to consider the environmental effects that may result from agency actions. One provision of NEPA requires the preparation of an Environmental Impact Statement by federal agencies when "major" actions are taken.

Radioactive mixed wasle: waste containing both radioactive and hazardous components regulated by the AEA and RCRA, respectively. The term "radioactive component" $\pi f e r s$ only 10 the actual radionuclides dispersed or suspended in the waste substance.

Radioactire waste: solid, liquid, or gasec'ss material thai contains radionuclides regulated under the Alomic Energy Act of 1954, as amended, and of negligible economic value considering costs oi recovery.

RCRA: Resource Conservation and Recovery Act of 1976. RCRA is an amendment to the first federal solid waste legislation, the Solid Waste Disposal Act of 1965. In RCRA, Congress established injtial directives and guidelines for EPA ro regulate hazardous wasles.

TRU: transuranic (containing transuranium nuclides).

Waste management: the planning, coordination, and direstion of those functions related to generation, handling, treament, slorage, uansponation, and disposal of waste, as well as associated surveillance and maintenance activities (DOE Order 5820.2A).

Waste minimization: the reduction, to the extent feasible, of hazardous waste that is generated or subsequently treated, stored, or dispssed of. It includes any source reduction or secycling activities underaken by a generator that results in cither (1) the reduction of total volume or quantity of hazardous waste, or (2) the reduction of toxicity of the hazardous waste, or both, so long as such reduction is consistent with the goal of minimizing present and future threats to human health and the environment (EPA's 'Report to Congress, 1986, EPA/530-SW-86-033). 


\section{References}

1. Laser Programs Policy Statement on Waste Minimization, internal memorandum, Lawrence Livermore National Labosatory, Livermore, CA (February 1990).

2. Director's Stalement on Waste Minimization, internal memorandum. Lawrence Livermore National Laboratory, Livermore, CA (March 8 1989).

3. Droff Guidance to Hazardous Widte Generasors on the Elements of a Waste Minimizosion Program. Federal Register Vol. 54, No. 111, Washington, DC (Monday, June 12, 1989).

4. Thomas E. Jliggins, Hozardous Waste Minimizarion Handbook. Lewis Publishers, Chelsea, MI (1989).

5. DOE Order 5820.2A, Radioacrive Wasse Management, Orfice of Defense Waste and Transporation Management, DOE Defense Programs, Washington, DC (September 26, 1988).

6. Implemenlation Guidance for DOE Order 5820.2A, Office of Defense Wasie and Transfonation Management, DOE Defense Programs, Washinglon, DC (Oclober 24, 1988).

7. DOE Order 5400.1, General Environmental Protection Progran, U.S. Deparnent of Energy. Washingion, DC (November 1988).

8. M A. Gonzalez, R. A. Heckman, LNL Site 300 Facility Waste Minimizorion Plon, Lautence Livermore Narional Laboratoly, Livermore, CA (Febraay 1990).

9. LUL Waste Minimizarion Program Plan, Rev. I, UCRL-21215, Lawrence Livermore National Laboralory. Livermore, CA (September 29, 1989).

10. Postings, intemal memorandum, V. A. Mode to A. Levy, Law. rence Livermore National Laboratory, Livermore, CA (December 7, 1989).

11. LWL Environmeniol Policy Stasement, internal memorandum, Lawrence Livermore National Laboratory, Livermore, CA (December 6, 1989).

12. C. E. DeGrange, Glossary of Enyitonmensal A cronyms \& Terms, UCAR-10301, Lawrence Livermore National Laboratory, Livermore, CA (July 1989). 
DIRECTORATE MINI PLAN

for

NUCLEAR DESIGN

○ 


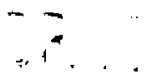

\title{
haSTE MINIMIZATION MANAGEMENT PLAN \\ LAWRENCE LIVERMORE NATIONAL LABORATORY \\ NUCLEAR DISÍ́N PROGRAM \\ SEPTEMBER 15, 1989
}

\author{
William B. Shuler \\ icting Associate Director \\ Nuclear Design Program
}




\subsection{QBJECLIVE}

This document presents the Nuclear Design Program management strategy for minimizing the future generation of hazardous, radioactive, and mixed waste at the Lawrence Livermore National Laboratory. When applicable, this plan shall also address the minimization of nonhazardous industrial wastes, in particular those wastestreams that cannot be released to the envi ronment or co sewer systems without treatment and, theref're, are processed as if they were hazardous.

\subsection{WASTE ULNIHIZATION EOLICY}

The Nuclear Design Program shall adopt the Laboratory's goal of reducing wastestreams by a major factor in the next three to five years by reducing generation and increasing recycling, as stat d in the Director's Statement on Waste Minimization dated March 8, 1989 . In working towards this goal, the Program shall comply with DOE Order 5820.2A and all applicable federal, state and local requirements.

\subsection{NUCLEAR DESIGN HASTESTREAMS}

The following section describes the major wastestreams generated by the Nuclear Design Program:

- Large volumes of waste (approximately 600 cubiry yards per year) is generated in high explosives tests conducted at Si te 300 . The wastestreams generated are most often classified as a low-level radioactive wasti because depleted uranium is used ir most of the tests. Beryllium, lear, copper, and barium are used in some experiments but, with the exception of lead, they have Been present in concentrations that do not exceed hazardous waste threshold limits. Operational changes were made-in 1987 to eliminate the use of lead bricks and to keep concentrotion bolow hazardous waste threshold levels.

- Large volumes of waste are also generated in the Engineering and Chemistry areas in support of Nuclear Design programs at the Livermore site. These wastes, are often classifies mixed wastes.

- Photochemical wastes are also generated in Nuclear Design Program facilities. The Site 300 wastestreans are collected and transported to Livermore for silver reclamation without volume reduction at the source. Photochemical wastes from Livermore also undergo silver reclamation processing. 
- Dils and cutting solutions are generated at several Program facilities. The Site 300 wastestreams are collected and transported to Livermore and are eventually reclaimed at on-site or off-site facilities. Livermore site oils and cutting solutions are ${ }^{\prime} \cdot$ ip reclaimed.

- Nonhazardous wastewaters are also generated by Nuclear Design. In some instances, these nonhazardous wastewaters exceed sewer discharge limits and, therefore, need to be processed as hazardous wastes. Typical contaminants are oil and giease, trace or Janies, and trace metals. 


\subsection{LHPLEMENTATION SPEROACH}

The plan to minimize the generation of wastes in Nuclear Design reguires consideration of the following strategies in the early stages of planning new experiments and facilities and in the management of current wastestreams. The general approach to be taken to implement waste minimization shall be as follows:

- Establisiz a review/audit process in the Nuclear Design Program that will ensure that waste minimization goals are being included in projects.

- Review future use of materials and survey facilities for current use of materials that will become hazardous waste.

- Yiilize the teshriques illustrated in Eigure 1, with the most desirable technique being source reduction, followed by recycling and, if source reduction and recycling are not feasible, treatment.

- Ensure that compliance is being achieved through regularly scheduled audits.

\subsection{RESPONSIBILITIES}

Associate Director

Program Leaders/

Eacility Managers

Frogram Experimenters
Assume responsibility for establishing waste minimization as a priority within the Nuclear Design Program.

Ensure that a system is in place to allow waste minimization objectives to be realized.

Ensure that waste minimization elements are included in experiments.

Oversee project teams involved with waste minimization treatability studies and implementatjon.

Evaluate materials to be used in experiments and strive to minimize the amount of hazardous. mixed or radioactive waste to be generated. 


\section{WASTE MINIMIZATION TECHNIOUES}

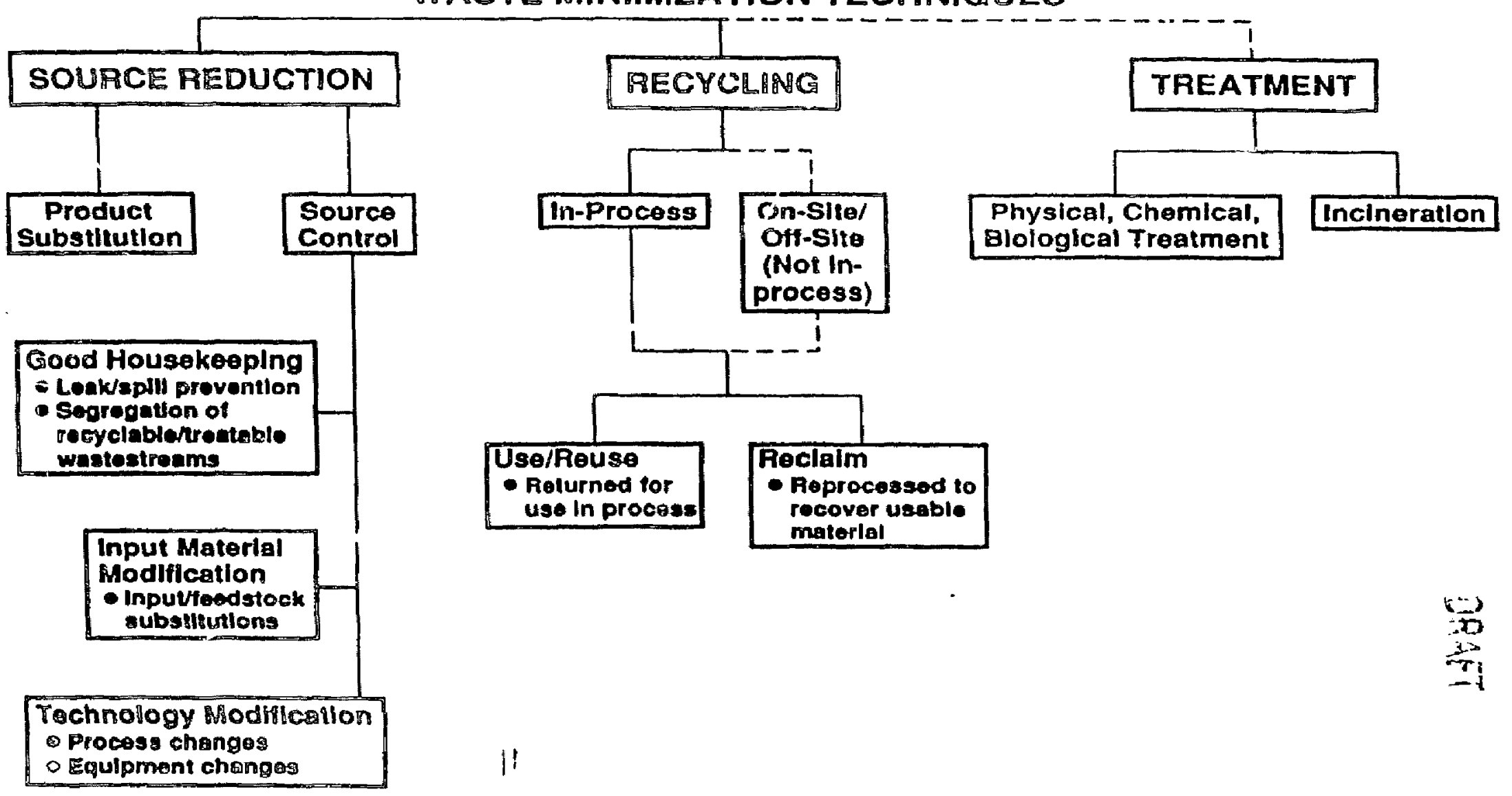

MAG 3/89

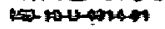

3

a 


\title{
Lawyrance Livermore National Laboratory
}

\section{Site 300 Facility}

\section{Waste Minimization Plan}

\author{
M. A. Gonzalez \\ Nuclear Design Program \\ R. A. Heckman \\ Environmental Protection Department
}

February 2. 1990 


\section{Preface}

The following Waste Minimization Pian has been prepared to reduce the volume and/or toxicity of hazardous, mixed, and radioactive wastes generated at Site 300 . This Plan, which has been prepared by LLNL's Nuclear Design Program (NDP) with assistance from LLNL's Environmental Protection (EPC) and Hazards Conirol (HC) Departments. describes the goals, management support, roles and responsibilities. waste targets, information transfer and reporting, and evaluation and auditing elements of NOP's Waste Minimization Program.

This Plan has also been prepared to meet the permit requirements specitied by the U.S. Environmental Protection Agency (EPA) in the Resource Conservation and Recovery Act (RCRA) permit lor the Building 883 Hazarcious Waste Storage Facility at Site 300 (EPA I.D. Number CA289009002) issued in 1989.

LLNL's Nuclear Design Program management endorses this Plan, and will include its elements in its existing and new activities.

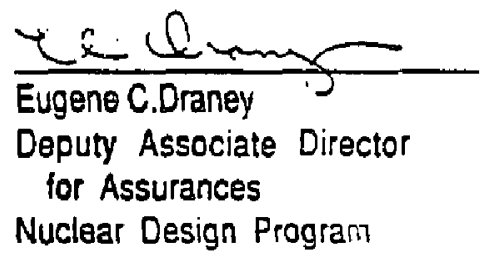




\section{Executive Summary}

Wasie minimization has received top management support at LLINL. A Waste Minimizatiun Plan has been developed for LLNL Site 30u, and it is being implemented by the programs and support organizations residing at the site.

Three major wastestreams have been identified at Sile 300 . They are: (1) debris gerierated trom the high explosives testing operations; (2) wastes from high explosive formulation and processing operations: and (3) miscellaneous wasies resulting from dynamic/physical and particie beam testing operations, machine shops, and general facility and equipment maintenance activities. Following characterization, work was initiated to identify potential alternatives for reducing the characterized wastestreams. In several areas, alternatives have already been selacien and imn!amented.

LLNL NDP management has established a waste reduction goal of $25 \%$ reduction over the next 3 to 5 years, with the base year being $C Y 1988$. It is NDP's intent to give priority to source reduction and recycling over treatment of wastes, employing methods that are technically feasible and economically practicable. 


\section{Site 300 Waste Minimization Plan}

\section{Eackground}

Site 300 comprises eleven square miles, located in both Alameda and San Joaquin counties. The site was established as a remote explosives iest facility to support nuclear weapons thecretical and developmental work pertormed at the LLNL Livermore Site for the U.S. Department of Energy (DOE). The Site 300 population is approximately 300 employees. including approximately 270 full-time employees and 30 supplemental workforce personnel. The aiea surrounding Site 300 is sparsely populated with the majority of land used to support sheep and cattle ranching operations and windmill power generators.

Site 300 is used primarily for performing high explosives tests with sophisticated diagnostics. Dynamic/therma! testing sperations, high explosives formulation and processing operations and, in recent years, particle beam research are also conducted at Site 300 . Site 300 -perations are conducted in conformance with federal, state, and local salety and environmental laws, DOE Orders, the LLNL Health and Safety Manual, and the Site 300 Safely and Operational Manual.

The industrial wastes generated at Site 300 include hazardous and low-leye radioactive wastes and, on occasion, mixed wastes.

Fccilities at Site 300 that generate hazardous wastes include the hign explosives lest firing tables with associated diagnostic and data recording operations, the dynamicthermal lesting operations, the particle beam research experiments, and ancillary support tacilities associated with conducting operations at Site 300 . The high explosives test operations also generate low-level radioactive wastes which primarily consists of depleted uranium and, infrequently, mixed waste which generally contains both depleted uranium and heavy metals.

The importance of minimizing waste generation through source reduction, recycling, and treatment has been acknowledged by Site 300 management. Through assessment of waste generating processes ard id. "ication of waste minimization alternatives, information is being $a b k c . . . J$ to implement the changes that will result in reductions in the toxicity and/or volume of wastes generated at Site 300 . 


\section{Waste Minimization Organization}

The Waste Minimization Policy Statement of March 8, 1989 (Attacnment 1), issued by the LLNL Laboratory Director, reflects the strong commitment by top management to implement waste minimization effors at $\mathrm{LI} \mathrm{NL}$. To reinforce the need for inclusion of thi Director's policy in daily operations, Nuciear Design Program management has also developed a more specific policy statement applicable to waste minimization at Site 300 (Attachment 2).

As illustrated in Figure 1, several LLNL organizations have roles and responsibilities in carrying out the Site 300 Waste Minimization Program. The Nuclear Design Program Deputy Associate Director (DAD) tor Assurances has the responsibility for management of Site 300 salety and environmental programs, as delegated by the Associate Difector for Nuclear Design (ND). The Site 300 Resident Manager has the responsibility for daily oversight of Site 300 safety and environmental programs. Knowledge of environmental compliance and operational safety requirements and implementation of these requirements is the responsibility of the programs and suppart organizations operating each facility of complex. Work is pertormed at these facilities in accordance with established Operational Safety Procedures and in compliance with environmental regulations. The DAD/ND, Site 300 Resident Manager, and program and operational support managers receive guidance and assistance in implementation from safety and environmental specialists assigned to Site 300 .

With respect to waste miniruization, the DAD/ND provides the system for reviewing and auditing programmatic and support activities io ensure that waste minimization goals are being addressed. The Sile 300 Fesident Mariager provides the oversight to ensure that routine operations receive the proper review to ensure that both LLNL and Site 300 waste minimization policies are being incorporated into activities. The Nuclear Design Waste Minimization Coordinator coordinates assessment and implementation activities of all Nuclear Design operations and ensures that Site 300 waste minimization information is cummunicated between Site 300 persénnel and LLNLDOE Waste Minimization Program personnel. 

Each Site 300 program and support organization manager establishes specific wste minimization goals and plans, and identifies and assigns responsibility for achieving these goals to a specific Waste Reduction Coordinator (WAC). In addition, program and support organization managers are responsible for ensuring that formal training of personnel in waste minimization and hazardous waste manejement practices is provided. and that required recordkeeping systems are implemented and maintalned.

The safety and environmental specialists from the hazards Control Department (HC) and the Environmental Protection Department (EPD) are responsible for providing interpretations of codes, standards, and DOE Orders, and for conducting lraining courses, evaluations, and audits, as requested by the DAD/ND. In addition, the Hazardous Waste Management Division Leader of LL. LL's EFD is responsible for operations conoucted in Buiding 883 and for ensuring that records and certifications required by 40 CFA 264.73 (b) (9) are maintained in the lacility operating record until closure of Building 883 .

\section{Waste Minimization Goals}

LLNL NDP management has established a Site 300 waste reduction goal of $25 \%$ reduction over the next 3 to 5 years, with the base year being CY9988.

\section{Waste Minimization Assessments and Proposals}

Waste minimization assessments conducted at Site 300 shall include three major steps: (1) information gathering; (2) identification and screening of potential waste minimization options; and (3) evaluation of te-trnical and economic aspects of potential options. Implementation of the recommended options shall follow the assessment process. At Site 300 , the waste minimization assessment process shall be an on-going program, not a one-time efiort. The DAD/ND shall arrange for an annual audit to identify additional oppontunities for source reduction and recycling. These annual reviews will emphasize the application of new lechnologies for waste reduction as they become known, with priority being given to source reduction and recycling over treatment of wastes, as illustrated by the example shown in Figure 2. 
The Hazardous Waste Division of EPD develops and maintains a waste accounting system to track the types, amounts, composition, and generation dates of all hazardous wastes. The Facility Hazardous Waste Report is based on data extracted from the HWM data base. The three major wastestreams generated at the site are: (1) debris from high explosives testing operations: (2) wastes from high exolosive formulation and processing operations; and (3) miscellanec us wastes resulting from dynamic/physical and particie beam testing operations, machine shop wastes, and general facility and equipment maintenance activities. Waste generation flow sheets for the 1988 base year are shown in Figures $3 a, 3 b$, and $3 c$. It should be noted that the percentages shown are based on the total waste volume (by weight), which was derived $j_{j}$ ' adding the volumes of the wastestreams shown in Figures $3 a, 3 b$, and $3 c$. 